\title{
In re Roger $S .:$ The Impact of a Child's Due Process Victory on the California Mental Health System
}

\section{TABLE OF CONTENTS}

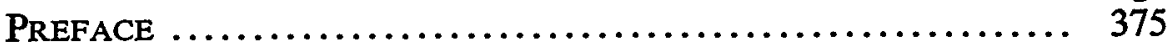

INTRODUCTION $\ldots \ldots \ldots \ldots \ldots \ldots \ldots \ldots \ldots \ldots \ldots \ldots \ldots \ldots \ldots \ldots \ldots, \quad 376$

I. Three Conflicting Perspectives................. 380

A. Parental Autonomy ........................... 380

B. The Medical Perspective ........................ 385

C. The Child's Legal Interests .................... 389

II. California Commitment Procedures.............. 394

A. The Lanterman-Petris-Short Act ................ 395

B. Institutionalization of Minors .................... 398

C. Admission to the State Hospital .................. 400

1. Camarillo State Hospital .................... 401

2. Napa State Hospital ....................... 402

III. THe Roger $S$. DeCISION........................ 404

A. The Opinion ............................... 405

B. Problems of Implementation .................... 408

1. The Hearing ............................. 408

2. The Facilities ........................... 410

3. The Admission Standard ..................... 412

C. The Court's Interim Solution .................... 413

IV. FALL-OUt FROM THE Decision................... 414

A. Impact at the State Hospital..................... 414

1. Immediate Fall-Out ....................... 415

2. Ongoing Impact ........................ 418

3. Turning Fourteen at Napa ................... 421

4. Going to Court ............................ 423

5. Summary of the Napa Experience .............. 424

B. Legislative Effort ............................ 426

1. The Proposed Legislation .................... 427

2. The Failure of the Lanterman Bill ............. 432

V. IMPACT ON THE COUNTIES ...................... 435

A. Conservatorship as an Admissions Tool ............ 436 
B. Voluntary Waivers of Roger S. Rights ............ 442

C. Roger S. Proceedings .......................... 445

D. Summary of the County Experience .............. 451

VI. RENEWEd LEgisLATIVE ATTEMPTS to

IMPLEMENT ROGER $S$. ............................ 453

A. Proposed Legislation ......................... 454

1. The Mental Health Advocates' Proposal .......... 454

2. The Sieroty Bill .......................... 457

3. Reexamination of LPS .................... 461

B. The Future of Roger S. Legislation .............. 463

VII. Conclusion..................................... 467

A. The Results of Roger S....................... 467

B. The Three Perspectives ........................ 469

C. Suggested Procedures for Implementing Roger S. .... 470

D. Suggested Interim Procedures ................... 471

E. A Lesson of Roger S. ........................ 472

Appendix A .......................................... 474

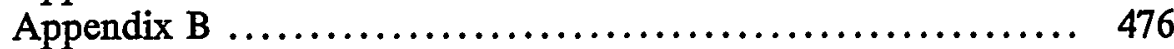

Appendix C ................................... 480 


\section{In re Roger $S .:$ The Impact of a Child's Due Process Victory on the California Mental Health System $\dagger$}

Dear Tom,

I want to get out of Napa State Hospital. I don't really feel $i$ should be here, because it's not really doing me any good. Please get me out/ They won't let me call you. They wrote a letter saying you can't call me and i'm mad about that. . . . I really feel like i'm gonna run if $i$ don't get out of here. I want to be put somewhere where they can help me with my problems. In a group home or a foster home.

$$
\begin{gathered}
\begin{array}{c}
\text { Sincerely } \\
\text { Roger }
\end{array} \\
\text { (The Red Head, with Angel Kisses) }^{1}
\end{gathered}
$$

He described himself as "The Red Head, with Angel Kisses;" he was diagnosed by doctors as a latent schizophrenic with suicidal tendencies. An attorney found him to be "rational, oriented." A psychiatrist reported he had a borderline I.Q. and a history of drug abuse. And the controversy over whether Roger belonged in a locked ward at Napa went all the way to the California Suprenie Court, changing the treatnient strategy for troubled adolescents across the state.

The California Suprenie Court in 1977 ordered Roger released and ruled that minors aged fourteen and older who object to institutionalization are constitutionally entitled to an administrative hearing to test the appropriateness of commitinent. But in throwing out the old systein that had allowed parents to sign unwilling children into the state hospital, the court erroneously assumed that the legislature would respond in a timely fashion with a new systein reflecting its newly pronounced due process rights. Five years later, the legislature still has not supphed a replacement scheine. So-called "interim" solutions have become pernianent.

We do not know what became of Roger once he left the state hospital. He may have become subnrerged in the anonymity of adulthood,

$\dagger$ The authors wish to express their appreciation to the many people-litigants and interested bystanders, state officials and county workers, lobbyists and legislators-who contributed their time and their ideas to the development of this Comment.

1. The letter was attached as Exhibit A to the Petition for Writ of Habeas Corpus, In re Roger S., 19 Cal. 3d 921, 569 P.2d 1286, 141 Cal. Rptr. 298 (1977) [hereimafter cited as Petition for Writ]. 
or perhaps in the "legal Bermuda Triangle"2 that this decision created. This Comment traces the theoretical roots and the practical impacts of the decision, not only through academic literature and judicial precedents, but also through interviews with those wlio participated in the litigation and with the state and county inental health personnel who have had general responsibility for implementing the court's directives.

\section{INTRODUCTION}

Roger started out not as a test case but as a troubled youth, being raised by a smgle nother in Humboldt County. ${ }^{3}$ Before his admission to Napa, he was living in an adolescent group home, but he was reinoved from the home for throwing rocks off a roof. His mother said he had threatened her. He had also allegedly threatened suicide.

A temporary conservator was appointed for Roger. ${ }^{4}$ In anticipation of further conservatorship proceedings, Humboldt County Deputy Public Defender Thomas Petersen was appoimted to represent him. He found Roger to be "rational, oriented, and in no sense gravely disabled or a danger to himself or others as a result of mental disorder."

Roger was exammed by several inental health professionals. One physician concluded that lie was "clearly not psychotic," and another recommended against placement in juvenile hall, sayimg Roger "cannot tolerate physical restraint and needs space." A psychologist described him as a "vulnerable youngster who has inost of his energy focused on his own self protection." "Yet he came to Napa with a diagnosis of "Unsocialized Aggressive Reaction of Adolescence in a Schizoid Person." At Napa, lie was diagnosed as a latent schizophrenic, and his Napa records revealed an I.Q. of 77, aggressive behavior, drug abuse, and suicide threats. ${ }^{7}$

There was apparently no commumity treatment program willing or able to accept Roger. When told that both the temporary conservator

2. Transcript of interview with Gwen Foster, director of children's services, Alameda County Health Care Services, at 11 (Oakland, Cal., Feb. 10, 1981) (on file with the California Law Review).

3. The factual background from which this Introduction is drawn was taken from Petition for Writ, supra note 1; Return to Order to Show Cause and Poimts and Authorities in Opposition to Petition for Writ of Habeas Corpus, Roger S., [heremafter cited as Brief for Respondent]; transcripts of interviews conducted with Ezra Hendon, deputy state public defender (San Francisco, Cal., Feb. 5, 1981) and Robert Walker, staff attorney, National Center for Youth Law (San Francisco, Cal., Feb. 12, 1981) (on file with the California Law Review); and telephone interview with Ronald E. Niver, deputy state attorney general (Feb. 3, 1981).

4. For a discussion of temporary conservatorships, see infra note 361.

5. Petition for Writ, supra note 1, at 2. It is Petersen to whoin Roger wrote the letter reproduced at the outset of this Comment.

6. Petition for Writ, supra note 1, at 13-14 (Declaration of Ezra Hendon).

7. Brief for Respondent, supra note 3, Exhibit A (letter from R.D. Kummer, M.D., adolescent treatment program director). 
and his mother were prepared to send him to Napa, Roger agreed to go voluntarily, but with the understanding that he would remain only a short time and would be permitted to leave when he wished. Conservatorship proceedings were terminated. Roger's mother executed an apphication for voluntary admission under Welfare and Institutions Code section 6000(b), which gave parents absolute control over the institutionalization of their children, tempered only by the admissions screening performed by county and state hospital staff. ${ }^{8}$

Roger entered Napa on May 10, 1976. It soon became clear to him that he would not be released at will. Instructions were placed in his file prohibiting contact with counsel: "All letters to Public Defender are to be returned. No [telephone calls] to or from Public Defender. No visit by the Public Defender." aged to write to Petersen, and Petersen filed a petition for writ of habeas corpus in Napa County Superior Court. The petition was denied without hearing. ${ }^{10}$

Not until that effort had failed was Petersen able to speak with Roger by telephone, and it would take intervention by the Califorina Department of Health before a personal visit was authorized. By then, the state public defender had been contacted and had agreed to represent Roger in further proceedings.

The state public defender's office had just been organized. The newly appointed state public defender took the case and pressed it directly before the California Supreme Court ${ }^{11}$ on the theory that it was a "hot issue" that would attract the court and a likely winner that would establish the reputation of the new office. ${ }^{12}$

Ezra Hendon was the deputy assigned to the case-his first and only professional involvement im the legal problenis of youth. Hendon contacted Robert Walker, an attorney with the Youth Law Center in

8. At the time that Roger $S$. was decided, CAL. WeLF. \& INST. CODE $\$ 6000$ (West 1972) provided:

Pursuant to the rules and regulations established by the State Department of Health, the medical director of a state hospital for the mentally disordered or mentally retarded may receive im such hospital, as a boarder and patient, any person who is a suitable person for care and treatment in such hospital, upon receipt of a written application for the admission of the person into the hospital for the care and treatment made in accordance with the following requirements:

(b) In the case of a minor person, the application shall be inade by his parents, or by the parent, guardian, or other person entitled to his custody to any of such mental hospitals as may be designated by the Director of Health to admit minors on voluntary admissions.

9. Petition for Writ, supra note 1, at I4 (Declaration of Ezra Hcndon).

10. Petition for Writ, supra note 1, at 16 (Exhibit C).

11. CAI. ConST. art. VI, $\S 10$ (West Supp. 1981) provides that the California Supreme Court may assume original jurisdiction over habeas corpns petitions.

12. Interview with Paul Halvonik, former state public defender (Berkeley, Cal., Jan. 27, 1981); Hendon transcript, supra note 3, at 3. 
San Francisco, who had prior experience with the issues of institutionalizing minors. Walker had successfully challenged the power of the juvenile court to place children in state hospitals ${ }^{13}$ and had brought a suit similar to Roger's which the court of appeal had held noot because the patient had been released before the case was heard. ${ }^{14}$ Walker entered Roger's case as amicus curiae and took part in the oral argument before the supreme court.

The court held that Roger had been cominitted without due process of law. ${ }^{15}$ The parental commitment decision, even when confirmed by state hospital staff, carried too inuch risk of error to stand alone. Mimors of fourteen or older, although im parental custody, were entitled to a precommitunent hearing before an administrative hearing officer and to many of the procedural rights associated with an adversary setting: notice, counsel, confrontation and cross-examination of opposing witnesses, presentation of one's own evidence, and a record adequate for review. ${ }^{16}$

Because they were opposing a parental commitment decision, rather than a cominitinent initiated by the state, mimors like Roger were not entitled to a jury trial, a judicial hearing, or findings beyond a reasonable doubt ${ }^{17}$-procedural rights held by adults and juvenile court wards cominitted involuntarily under the Lanterinan-Petris-Short Act (LPS), California's comprehensive statutory inental health scheme. ${ }^{18}$ Moreover, while adults or wards could not be committed unless they were gravely disabled, the Roger $S$. court approved the parental commitment of minors if state hospital treatment was "reasonably likely to be beneficial." 19

In rendering the decision, the court abohshed the use of section 6000 (b) for involuntary commitment of minors aged fourteen and older, anticipating that the legislature would respond by adopting new legislation to provide a commitment scheme that guaranteed due process rights. ${ }^{20}$ "In the interim," the court noted, LPS was available to assure treatment to those minors who qualified as gravely disabled or dangerous to self or others. ${ }^{21}$ Finally, the court anticipated that state and/or county public defenders would identify and assist all minors

13. In re L.L., 39 Cal. App. 3d 205, 114 Cal. Rptr. 11 (1st Dist. 1974).

14. In re Paul J.B., No. 1 Crim. 14811, slip op. (1st Dist. June 20, 1976).

15. 19 Cal. 3d at 927,569 P.2d at 1289, 141 Cal. Rptr. at 301.

16. Id. at $937-38,569$ P.2d at 1296,141 Cal. Rptr. at 308.

17. Id. at $938-39,569$ P.2d at 1297,141 Cal. Rptr. at 309 . The standard adopted by the Roger $S$. court was preponderance of the evidence.

18. Id at $934-35,569 \mathrm{P} .2 \mathrm{~d}$ at $1294,141 \mathrm{Cal}$. Rptr. at 306.

19. Id. at $940,569 \mathrm{P} .2 \mathrm{~d}$ at $1298,141 \mathrm{Cal}$. Rptr. at 310 .

20. Id. at $940 \mathrm{n} .11,569$ P.2d at $1298 \mathrm{n} .11,141$ Cal. Rptr. at $309 \mathrm{n} .11$.

21. Id. 
currently in the state hospital who requested release in hight of Roger $S .^{22}$

These three assumptions created several problems for the state mental health system. The state hospitals were unprepared for the burden of providing legal process to institutionalized adolescents. The legislature was unwilling to cooperate with the court's directive, rejecting all attempts to enact a statutory Roger $S$. scheme. And the fifty-eight California counties that provide frontline treatment for mentally disturbed minors were unable to fill the void and provide consistent workable substitutes for section $6000(\mathrm{~b})$.

Given the shockwaves that this decision sent through the state mental health system, it is noteworthy that the attorney who pressed Roger's case was not so inuch motivated by a philosophical commitment to abohishing institutionalization as by the heartrending story told by the boy himself. Yet Hendon called section 6000 , the statute used to commit Roger, "indefensible." About Napa, he said, "There's nothing good about the place. The only thing that there is about it is that there's a bed and there's ineals. And there may be some inarginal kids for whom the shock value of being there is enough to wake them up and turn their lives around."23

Even after the victory in Roger $S$., Hendon does not view mental health treatment as a legal problem. He is not "one hundred percent convinced" about the role of law and of due process considerations in the treatment of inentally disturbed minors. "The question ought to be what's the best place to put these kids. And I think if we had good places to put these people, there would be less fighting in making the threshold determination."24

As it is, there is intense fighting. Great hostility exists between the two professional groups who coine in contact with these children: lawyers and doctors. The lawyers for the most part see the decision to institutionalize as a due process problem, imphicating a child's hberty mterest in the same way prison infringes upon a convict's freedom. The doctors make a inedical diagnosis of an illness and prescribe treatment; they see legal rights as only shightly more relevant here than in deciding whether to perform an appendectomy.

There is also a third perspective that cannot be ignored, especially by a court charged with the responsiblity of balancing all interests in resolving disputes. The parents of these children often have reached wits' end by the time the issue of commitment arises. Yet they are often reluctant to abdicate responsibility for their children's care to strangers, much less to the child himself.

22. Id. at $940 \mathrm{n} .12,569 \mathrm{P} .2 \mathrm{~d}$ at $1298 \mathrm{n} .12,141$ Cal. Rptr. at $310 \mathrm{n} .12$.

23. Hendon transcript, supra note 3, at 2, 3, 7 .

24. Id. at 4,11 . 
This Comment will' explore both the theoretical imphications and the practical consequences of the Roger $S$. decision. Part I discusses the theoretical models open to the court, the traditional conflict between the legal and medical models, and the comphicatimg factor of parental rights. Part II describes the structure of the California mental health system, its statutory framework, and the trcatment programs available at the state hospital. Part III outlines the effect of the court's opinion on that mental health structure, emphasizing those aspects of the decision that would impede successful implementation of the due process rights the court deemed appropriate. Part IV rccounts the effects the decision had on the population and practices at the state hospital and the early unsuccessful efforts to pass legislation. Part $\mathrm{V}$ summarizes how the counties reacted to the decision and improvised commitment schemes. Part VI updates ongoing efforts to legislate a solution to the problems caused by Roger $S$. Fimally, this Comment concludes with a summary of the problems caused by the Roger $S$. decision and a number of recommendations for the future.

I

\section{Three Conflicting Perspectives}

Three theoretical models for approaching the decision to commit a child involuntarily are based upon the different interests and perspectives of parents, doctors, and children. The parental autonoiny model assumes that parents are interested in the well-being of their children and are the inost qualified to decide what is in their children's best interests. This model relies upon parents to make inuportant decisions affectimg their children. The second model, the inedical model, is concerned with the delivery of psychiatric treatment to those who need it. It seeks to protect the individual from mental illness and rehes on the expert opinions of psychiatrists to determine who shall be committed for treatment. The third model's concern is the protection of the right of an individual, in this case the child, not to be deprived of liberty without due process of law. It protects individuals from arbitrary government action by requiring procedural protections before they can be deprived of liberty. Because of these different perspectives, the three models often imply very different procedures for committing a child imvoluntarily to a mental institution.

\section{A. Parental Autonomy}

The parental autonomy approacli views the family as an independent umit-antedating the state, not created by, $i^{25}$ - for which

25. "[T]he traditional relation of the family [is] a relation as old and as fundamental as our entire civilization." Griswold v. Connecticut, 381 U.S. 479, 496 (1965) (Goldberg, J., concurring). 
the parents speak. ${ }^{26}$ Parents, not the state, are responsible for "the custody, care and nurture of the child," 27 and their right to "bring up children"28 is constitutionally protected. ${ }^{29}$ This approach assumes that parents are motivated by love to act in their children's best interests and that their close relationship enables parents to determine accurately what their children's best interests are. The state overturns this presumption of parental power and assumes decisionmaking authority for the child only if "it appears that the parental decisions will jeopardize the health or safety of the child or have a potential for significant social burdens." 30 The state's perception of a significant social burden,

See Moore v. City of East Cleveland, 431 U.S. 494, 503 (1977) ("the institution of the family is deeply rooted in this Nation's history and tradition"); Ginsberg v. New York, 390 U.S. 629, 639 (1968) ("the parents' claim to authority in their own household to direct the rearing of their children is basic in the structure of our society").

26. In the eyes of the law, to be a child is to be at risk, dependent, and without capacity or authority to decide free of parental control what is "best" for oneself. To be an adult is in law to be perceived as free to take risks, with the independent capacity and authority to decide what is "best" for oneself without regard to parental wishes. To be an adult who is a parent is therefore to be presumed by the law to have the capacity, authority, and responsibility to determine and to do what is "good" for one's children, what is "best" for the entire family.

J. Goldstein, A. Freud \& A. Solnit, Before the Best Interests of the Child 7 (1979) (einphasis in original) [hereinafter cited as J. Goldstein]. See Parham v. J.R., 442 U.S. 584, 602 (1979) ("natural bonds of affection lead parents to act in the best interests of their children"). See generally Developments in the Law: The Constitution and the Family, 93 HARv. L. Rev. 1I56, 116197 (sources of constitutional protection of family rights), 1350-83 (parent-child relationship) (1980).

27. Prince v. Massachusetts, 321 U.S. 158, 166 (1944).

28. Meyer v. Nebraska, 262 U.S. 390, 399 (1923).

29. The Supreme Court has found protection for various aspects of family life in the due process and equal protection clauses of the fourteenth amendment and in the ninth amendment as well. See, e.g., Pierce v. Society of Sisters, 268 U.S. 510 (1924) (due process clause protects right of parents to direct their children's upbringing); Skinner v. Oklahoina, 316 U.S. 535, 541 (1942) (equal protection clause protects right of inarriage and procreation); Griswold v. Connecticut, 381 U.S. 479, 496 (1965) (Goldberg, J., concurring) (ninth amendment protects right of marital privacy, which includes right to use contraception). More recently the Court has emphasized the doetrine of substantive due process as a basis for its protection of family integrity. See, e.g. Moore v. City of East Cleveland, 431 U.S. 494, 503-04 \& n.12 (1977) (invalidating overly restrictive definition of "family" in single family zoning ordimance).

As against state intervention, this parental right has been held to include the control of the child's education, Pierce v. Society of Sisters, 268 U.S. 510 (1925); Meyer v. Nebraska, 262 U.S. 390 (1923), rehgion, Wisconsin v. Yoder, 406 U.S. 205 (1972), access to reading material that the state deeins obscene, Ginsberg v. New York, 390 U.S. 629 (1968), and medical care, Parham v. J.R., 442 U.S. 584, 604 (1979).

30. Wisconsin v. Yoder, 406 U.S. 205, 234 (1972) (state may not compel Amish parents to send their children to school beyond 8th grade). See CaL. Welf. \& INST. Code $\$ 300$ (West 1972) (listing grounds under which state may declare child dependent ward of juvenile court in order to protect child froun neglect or abuse). Such statutes have been challenged as unconstitutionally vague. See, e.g., Alsager v. District Court, 406 F. Supp. 10 (S.D. Iowa 1975), affd, 545 F.2d 1137 (8th Cir. 1976).

Professor Wald has suggested that several factors should be considered

[i]n determining whether to remove the decision-making authority from the parents . . . [includimg] whether other decision-ınakers, or decision-making processes, are likely to arrive at better decisions than the parents . . . [and] the costs of removing the decision 
however, will vary with time and with changing perceptions of what is in a child's best interest. ${ }^{31}$ Similarly, what threatens a child's health depends in large part on who is looking at the child and how that person defines health. ${ }^{32}$

Decisions regarding children's medical care are traditionally withm the parental sphere. ${ }^{33}$ Normally, the state inay override parental authority only if the child's hife is threatened. ${ }^{34}$ But some courts, under the banner of child protection, have sanctioned state intervention to correct a condition that posed no threat to the child's life. For exainple, in one case the New York Fainily Court ordered dangerous surgery to be performed on a fifteen-year-old boy, despite his mother's religious objection to blood transfusions, in order to correct a disfigurimg but not fatal facial condition. ${ }^{35}$ Anotlier court held that parents alone could not authorize the removal of a healthy child's kidney for transplanting to her seriously ill twin. The surgery was performed on the child only "after a close, independent and objective mvestigation of [the parents'] motivation and reasoning." ${ }^{36}$ In both situations, the pa-

from the parents in terms of family autonomy and family privacy (both valued goals in our society)....

Wald, Children's Rights: A Framework Analysis, 12 U.C.D. L. REv. 255, 271 (1979). A perceptive student Note has identified five commonly advanced justifications for parental authority: (1) an interest in fostering social pluralism by permitting families rather than the state to make childrearing decisions, (2) the efficacy of families for socializing children and thereby furthermg social order, (3) a general parental privilege rooted in the interests of parents, (4) an interest in preserving the family unit, and (5) the child's welfare, which is best served by a broad grant of parental authority. Note, The Mental Hospitalization of Children and the Limits of Parental Authority, 88 YALE L.J. 186, 194-209 (1978) (rejecting these interests as insufficient to justify state support of parental authority to commit adolescents).

31. See generally Mnookin, Child-Custody Adjudication: Judicial Functions in the Face of Indeterminacy, 39 LAW \& CONTEMP. ProBs. 226 (1975) (discussing the indeterminacy of the "best interests of the child" standard).

32. Compare In re Seiferth, 309 N.Y. 80, 127 N.E.2d 820 (1955) (court refuscd to order nonlifesavimg surgery over objections of parent and child) with In re Sampson, 29 N.Y.2d 900, 278 N.E.2d 918, 328 N.Y.S.2d 686 (1972) (court ordered surgery for non-life-threatening condition over objections of parent without consulting child).

33. See, e.g., In re Phillip B., 92 Cal. App. 3d 796, 156 Cal. Rptr. 48 (1st Dist. 1979) (parents of child with Downs Syndrome inay refuse risky but potentially lifesaving heart surgery for thcir child; state petition for dependency deried).

34. See, e.g., Raleigh Fitkin-Paul Morgan Memorial Hosp. v. Andcrson, 42 N.J. 421, 201 A.2d 537 (state may compel pregnant Jehovah's Witness to accept blood transfusion to prcserve imfant's life in delivery), cert. denied, 377 U.S. 985 (1964).

35. In re Sampson, 65 Misc. 2d 658, 317 N.Y.S.2d 641 (1970), affd, 37 A.D.2d 668, 323 N.Y.S.2d 253 (1971), affd, 29 N.Y.2d 900, 278 N.E.2d 918, 328 N.Y.S.2d 686 (1972). The decision Las been criticized as an egregious example of judicial arrogance. See, e.g., J. GoldsTEIN, supra note 26, at 101-05. For a diffcrent view of a similar situation, sce In re Seifcrth, 309 N.Y. 80,127 N.E.2d 820 (1955) (where parent and child both opposed surgery to repair cleft palate and cooperation was essential for surgery's success, court refused to order surgery); see also In re Grcen, 448 Pa. 338, 292 A.2d 387 (1972) (refusing to override religiously bascd parental objcctions to surgery where child's condition posed no immediate peril to his life).

36. Hart v. Brown, 29 Conn. Supp. 368, 378, 289 A.2d 386, 390 (1972). Parental power to 
rental autonomy approach would have precluded state involvement.

Courts have intruded even further into parental autonomy in cases mvolving adolescent abortions. The constitutional right to decide whether a minor will have an abortion belongs not to the girl's parents but to the pregnant minor herself. ${ }^{37}$ A state may constitutionally require that her parents be notified of the proposed abortion ${ }^{38}$ or require that she either obtain parental consent or secure judicial consent or a judicial determination that she is mature enough to consent for herself. $^{39}$ It may not, however, require parental approval in all cases.

In the mid-1970's, two lower federal courts intruded into family autonomy im the commitment of children to mental hospitals. Shortly before Roger $S$. was decided, federal district courts in Pennsylvania ${ }^{40}$ and Georgia ${ }^{41}$ concluded that minors, like adults, ${ }^{42}$ have a constitution-

consent to surgery for the recipient twin was apparently unquestioned, for the court did not mention it.

37. Planned Parenthood v. Danforth, 428 U.S. 52 (1976). The Court held that neither state, spouse, nor parent may veto a ininor's abortion decision. "[C]onstitutional rights do not mature and come into being magically only when one attains the state-defined age of majority. . . . Any independent interest the parent may have in the termination of the minor daughter's pregnancy is no more weighty than the right of privacy of the competent minor inature enough to have become pregnant." Id. at 74-75. The Court rejeeted the state's argument that placing the decision in parental hands protected family autonomy and parental authority. "[W] non-consenting parent are so fundainentally in conflict . . . the very existence of the pregnancy already has fractured the family structure." Id. at 75. See also In re Smith, 16 Md. App. 209, 295 A.2d 238 (1972) (parents may not coinpel minor daughter to terminate pregnancy against her will).

38. H.L. v. Matheson, 101 S. Ct. 1164 (1981). In Matheson, the Supreme Court upheld a Utah statute requiring a physician to notify, if possible, the parents of any minor who sought an abortion. The statute promoted "important considerations of family integrity and protecting adolescents" without inpinging unduly on the rights of the pregnant ininor. Id. at 1172 . Justice Powell concurred separately to emphasize that the Court's opmion "leaves open the question of whether [requiring notice] unconstitutionally burdens the right of a mature minor or a minor whose interests would not be served by parental notification." Id. at 1173-74 (Powell, J., concurring). H.L. had apparently not alleged either that she was mature enough to decide for herself or that parental notice would harun her. Id. at 1169-70.

39. Bellotti v. Baird, 443 U.S. 622 (1979). The Bellotti Court imvalidated a Massachusetts statute requiring a pregnant minor to obtain both parents' consent for an abortion or, if they refused, the consent of a superior court judge. The trouble with the statute, according to Justice Powell, was:

First, it permits judicial authorization for an abortion to be withheld from a minor who is found by the superior court to be mature and fully competent to make this decision independently. Second, it requires parental consultation or notification in every instance, without affording the pregnant minor an opportunity to receive an independent judicial determination that she is mature enough to consent or that an abortion would be in her best interests.

Id. at 651 .

40. Bartley v. Kremens, 402 F. Supp. 1039 (E.D. Pa. 1975), vacated, 431 U.S. 119 (1977) (statute enacted after trial, treating those 14 and over as adults, mooted issue for named plaintiffs); see Institutionalized Juveniles v. Secretary of Pub. Welfare, 459 F. Supp. 30 (E.D. Pa. 1978), rev'd, 442 U.S. 640 (1979) (voluntary commitment statute allowing parents, after independent psychiatric review, to commit children under 14 satisfied due process requireinents).

41. J.L. v. Parham, 412 F. Supp. 112 (M.D. Ga. 1976), rev'd, 442 U.S. 584 (1979) (voluntary 
ally protected right not to be committed imvoluntarily to a state mental hospital without due process of law. Parental autonony in the commitment context, they felt, could lead to improper placements, either from parental ignorance of less drastic modes of treatment, despite good intentions, or from a desire to get rid of responsibility for a troublesome family member. ${ }^{43}$

While some courts have worried about children who are improperly committed through undue deference to parental autonomy, some mental health workers are concerned about those children who need treatment but whose parents will not allow them to be treated. For example, a child's behavior may cause school authorities or the police to refer him to the local mental health agency. If parents refuse to permit their child's treatment-whether from fear, ignorance, aversion to any implication of fault on their part, or rejection of state involvement in such an intimate area-short of instituting neglect proceedings, there is little the agency can do. ${ }^{44}$

Despite these problems with parental autonomy, the Umited States Supreme Court in Parham v. J.R. ${ }^{45}$-decided two years after Roger $S$.-refused "to discard wholesale those pages of human experience that teach that parents generally do act in the child's best imterests." 46 Although Parham concluded that committing a child to a state mental hospital was subject to due process limits, those limits were narrow. Due process required only that the decision be reviewed by an imdependent inental health professional who could override the parental decision if he found it necessary ${ }^{47}$ Otherwise, the decision was within the sphere of "the parents' authority to decide what is best for the child." 48

Like other forms of medical treatment, however, psychiatric hospitalization requires the participation of doctors. The Supreme Court beheved that astute doctors could and would screen out families who only

commitment statute allowing parents to commit their minor children, after independent psychiatric review, met due process requirements); see infra note 207.

42. See infra text accompanying notes 81-84.

43. J.L. v. Parham, 412 F. Supp. 112, 138 (M.D. Ga. 1976), rev'd, 442 U.S. 584 (1979); Bartley v. Kremens, 402 F. Supp. 1039, 1047-48 (E.D. Pa. 1975), vacated, 431 U.S. 126 (1977).

44. See infra text accompanying note 365 .

45. 442 U.S. 584 (1979).

46. Id. at 602-03. See In re B.G., 11 Cal. 3d 679, 694, 523 P.2d 244, 254, 114 Cal. Rptr. 444, 454 (1974) (custody disputc) ("a parent fit to exercise custody may have a better understanding of the best interests of his child than does the juvenile court").

47. 442 U.S. at 606-08. The Court quoted Justice Clark's cominent in Roger $S$. that "neither judges nor administrative hearing officers are better qualified than psychiatrists to render psychiatric judgments." Id. at 607 (quoting $19 \mathrm{Cal}$. 3d at 942, $569 \mathrm{P} .2 \mathrm{~d}$ at 1299, $141 \mathrm{Cal}$. Rptr. at 311 (Clark, J., dissenting)).

48. 442 U.S. at 604. 
wished to get rid of a difficult child. ${ }^{49}$ Indeed, whether parents are seen as knowledgeable and concerned or ignorant and hostile, nobody has argued that parents should be able to commit a child when hospital mental health staff members feel institutional treatment is improper. ${ }^{50}$ Thus, the attitude of inental health professionals toward the commitment of minors is crucial.

\section{B. The Medical Perspective}

The basic premise of the medical perspective is that the medical profession should control decisions concerning commitment to inental mstitutions because the primary purpose of commitment is medical treatment. The mam risk under this model is the chance that inaccurate diagnoses might lead to unnecessary commitments. The debate between the legal and inedical professions therefore centers on the magnitude of this risk and on who is best qualified to minimize it.

In theory, the medical model serves as a check on parental autonomy, since doctors must approve any parental decision to commit a child. The commitment process typically begins when a parent or guardian requests, often on the advice of a doctor, that the child be committed to an institution. The medical model then gives a psychiatrist the ultimate authority to accept or reject the commitınent. Reliability of commitınent decisions thus rests on admitting psychiatrists' special traming to diagnose and treat mental illness and their devotion to acting in the patient's best interest.

In practice, there are many variations on this basic framework. Not only parents but juvenile authorities, schools, social workers, and other social institutions bring children with problems to the attention of mental health professionals. The relation between the person who initiates a possible commitment and the medical person wlio screens that decision also varies considerably. Some parents can afford to hire hospital services directly froin private institutions, while others must rely on public institutions where doctors are paid by the state. Nevertheless, the common check in all these situations is that a psychiatrist is supposed to make a decision to commit or refuse to commit a minor solely on the basis of medical criteria.

The medical model was approved by the United States Supreme Court in Parham v. J.R. ${ }^{51}$ The Court in that case lield that an involuntary commitınent to a state mental institution does not violate a child's due process rights where a staff psychiatrist investigates the child's con-

49. Id at 611.

50. See, eg., CAL. Welf. \& INST. CODE $\S 6000$ (West Supp. 1981) (proposed patient must be "suitable for care and treatment in such hospital").

51. 442 U.S. 584 (1979). 
dition and makes the final decision. The Court reasoned that since "the questions are essentially medical in nature," this deferral to psy. chiatric discretion is appropriate because psychiatrists are more qualified than others to determine which children need treatment in a mental institution. 52 The Court was also concerned that "time-con. suming procedural minuets" might deter people from seeking needed assistance and might shift limited state resources away from diagnosis and treatment. ${ }^{53}$ The Parham Court rejected the notion that the state should interfere with the joint decision of parents and psychiatrists simply because some parents might abuse or neglect their children. ${ }^{54}$

There are, however, reasons to doubt the accuracy of psychiatric opinions, and this is one of the primary problems with the inedical model. Chief Justice Burger, author of the Parham opinion, has noted elsewhere that "[t]here can be little responsible debate regarding the uncertainty of diagnosis in this field and the tcntativeness of professional judgment."55 Other courts have made similar and stronger stateinents. ${ }^{56}$ Indced, the evidence on the inaccuracy of psychiatric and psychological diagnosis is little short of devastating. ${ }^{57}$

A coinprehensive article on the accuracy of psychiatric determinations, written by a lawyer and a psychologist, examined both the reliability and the validity of psychiatric opinions. ${ }^{58}$ Reliability is the extent to which two or more psychiatrists agree on a psychiatric conclusion given a single set of facts; validity is the extent to which psychiatric conclusions accurately reflect reality. ${ }^{59}$ After examining numerous studies, the authors concluded that both the reliability and the validity

52. Id. at 609,613 . The Court stated that "an independent medical decision-making process, which includes [a] thorough psychiatric investigation . . . followed by additional periodic review of a child's condition, will protect children who should not be admitted; we do not believe the risks of error in that process would be significantly reduced by a nore formal, judicial-type hearing." Id. at 613.

53. Id at 605. The Court said it wished to avoid turning "ratioual decisionmaking into an unmanageable enterprise." Id. at 608 n.16.

54. Id at 603. For children without natural parents, the Court said that the state custodial agency could "constitutionally . . . speak for the child." Id. at 619. But see Johnson v. Solomon, 484 F. Supp. 278, 293 (D. Md. 1979) (characterizing the civil commitment of wards as involuntary and holding that "[w]hen it is the state which, in effect, has become the child's family, a more independent, adversary-type review of commitmont is required").

55. O'Connor v. Donaldson, 422 U.S. 563, 584 (1975) (Burger, C.J., concurring) (stating that a state violated an individual's constitutional right to freedom by refusing to release him from a mental institution even though he was nondangerous and was capable of surviving safely by himself).

56. See, e.g., Sarzen v. Gaughan, 489 F.2d 1076, 1086 (1st Cir. 1973); Conservatorship of Roulet, 23 Cal. 3d 219, 230, 590 P.2d 1, 7, 152 Cal. Rptr. 425, 431 (1979).

57. See, e.g., J. Ziskin, Coping with Psychiatric and Psychological Testimony (2d ed. 1975); Rosenhan, On Being Sane in Insane Places, 13 SANTA Clara LAw. 379 (1973).

58. Ennis \& Litwack, Psychiatry and the Presumption of Expertise: Flipping Coins in the Courtroom, 62 CALIF. L. REv. 693 (1974).

59. Id at 695 . 
of psychiatric judgments are very poor. ${ }^{60}$ The authors found that "psychiatrists disagree frequently on broad diagnostic judgments" and "more often than not on more specific diagnoses." 61 They also concluded that psychiatric diagnoses frequently do not comport with reality and "often convey more maccurate than accurate information about patients."

Others who have studied the accuracy of psychiatric judgments have reached similar conclusions. For example, one well-known study conducted in several mental hospitals found that the staffs of those hospitals, including psychiatrists and psychologists, were unable to distinguish sane "pseudopatients" from the true patients. ${ }^{63}$ Another author, who is both a lawyer and a psychologist, has concluded that psychiatric judgments are highly unrehiable and that the chances of one psychiatrist agreeing with the diaguosis of another "are barely better than 50$50 . "$ 64

The low reliability of psychiatric judgments is probably the result of the highly subjective nature of psychiatric diagnoses and the complexity of the symptoms of mental disorders. A psychiatric diagnosis is simply a psychiatrist's inferences about another person's mental state based on that person's behavior. This interpretation will be affected by, among other things, which of the competing schools of thought the psychiatrist subscribes to, the psychiatrist's training, the importance lie attributes to various behaviors, his expectations of the patient, and his particular view of what does and does not constitute a mental disorder. ${ }^{65}$ As a result, when faced witl abnormal behavior, psychiatrists will often disagree about its significance and meaning.

When psychiatrists and other inental liealth professionals err, there is a strong tendency to err on the side of overdiagnosis. ${ }^{66}$ Psychiatrists are far more likely to call a healthy person sick than to call a sick person liealthy. The most important reason for this tendency is probably the desire to avoid the consequences of an error in the other direction. It is generally safer to err on the side of caution in the medical profession by assuming disease rather than health. ${ }^{67}$ Other factors that contribute to the tendency to overdiagnose include differences in class

\footnotetext{
60. Id. at $707,709$.

61. Id. at 707-08.

62. Id. at 719.

63. Rosenhan, supra note 57 , at $384-85$.

64. J. ZISKIN, supra note 57, at 186.

65. See Ennis \& Litwack, supra note 58, at 719-34.

66. See, e.g., Rosenhan, supra note 57 , at 385.

67. Bazelon, Institutionalization, Deinstitutionalization, and the Adversary Process, 75 CoLuM. L. Rev. 897, 900 (1975); Dershowitz, Psychiatry in the Legal Process: A Knife That Cuts Both Ways, Trial, Feb.-Mar. 1968, at 32-33; Ellis, Volunteering Children: Parental Commitment of Minors to Mental Institutions, 62 CALIF. L. REv. 840, 865-66 (1974); Rosenhan, supra note 57, at 385.
} 
and cultural background between the clinician and patient; ${ }^{68}$ a tendency to diagnose illness when the examination is made in surroundings such as a hospital, where illness would normally be expected to be found; ${ }^{69}$ and attitudes and values of psychiatrists, as individuals and as a group, which may predispose them toward certain diagnoses. ${ }^{70}$ It has also been suggested that "psychiatrists as a group are likely to be paternalistic and therefore relatively insensitive to considerations of civil liberty," and, despite their protestations to the contrary, some "may be susceptible to family pressures to commit."71

Several studies confirming this tendency to overdiagnose were conducted in the wake of the Supreme Court's decision in Baxstrom v. Herold. ${ }^{72}$ That decision held unconstitutional, on equal protection grounds, a statute that allowed mentally ill prisoners to be detamed beyond the expiration of their sentences in hospitals for the criminally insane, without jury trial or the judicial determination of dangerousness to which all other civilly committed persons were entitled. Some 969 inmates were transferred to civil hospitals as a result of the decision. ${ }^{73}$ When these patients were studied one year after the decision, virtually no problems had arisen, even though some officials had estimated that as many as one-fourth of the inmates were too dangerous for civil facilities. ${ }^{74}$ After one year, only seven patients had been certified as too dangerous for a civil hospital; slightly more than 200 had been released; and the rest had been absorbed into the general civil hospital patient population. ${ }^{75}$

Follow-up studies four years later, based on statistical sampling teclıniques, found similar results. Twenty-seven percent of the sample group were living in the community, and three percent were in a correctional facility or a hospital for the criminally insane. ${ }^{76}$ Only seventeen percent of all patients released to the commumity had been rearrested, and no way was found to predict accurately who these patients would have been. ${ }^{77}$ These studies show that the vast majority of the Baxstrom patients had been held in institutions that were far more

68. Bazelon, supra note 67, at 900; Ennis \& Litwack, supra note 58, at 724-26 and sources cited therein.

69. Ennis \& Litwack, supra note 58, at $722-23$ and sources cited therein.

70. Id. at 726-29 and sources cited therein.

71. Id. at $729 \& \mathrm{n} .127$.

72. 383 U.S. 107 (1966).

73. Hunt \& Wiley, Operation Baxstrom After One Year, 124 AM. J. Psychiatry 974, 975 (1968).

74. Id.

75. Id. at 978 .

76. Steadman \& Keveles, The Community Adjustment and Criminal Activity of the Baxstrom Patients: 1966-70, 129 AM. J. Psychlatry 304 (1972).

77. Steadman, Follow-Up on Baxstrom Patients Retumed to Hospitals for the Criminally Insane, 130 AM. J. PsychlaTRY 317, 318 (1973). 
restrictive than necessary; they reveal the dangers of dispensing with legal procedural protections when medical experts decide that someone is insane. ${ }^{78}$

Although the authors have found no studies specifically addressing the accuracy of psychiatric judginents concerning the commitment of children, the findings of the foregoing studies are probably applicable to all commitinent decisions. It has been estimated that at least five to fifteen percent of all children committed to inental hospitals do not belong there. ${ }^{79}$ This uncertainty is one of the major problems with relying upon inedical personnel to screen out those children who should not be involuntarily committed to inental institutions. On the other hand, medical professionals argue that there is no reason to believe that any other decisionmakers would be able to resolve this coinplex question with a greater degree of certainty.

Another opjection to placing the ultimate authority to commit a child in the hands of a doctor is that medical persounel may not fully appreciate the child's interest in not being committed. As will be discussed in the next section, the child has a constitutional right to liberty. The medical emphasis on the importance of treatinent is likely to lead to a deemphasizing of the child's liberty interest, and the tendency to "overdiagnose" 80 may further tip the scales against this right. The legal model of commitinent is based on the importance of avoiding inappropriate commitinents and asserts that some sort of lcgal procedural protections will serve this goal.

\section{The Child's Legal Interests}

The model that focuses on the child's legal rights is based on the legal rights of adults in similar circumstances. The law approaclies the involuntary commitment of adults to mental institutions through the constitutional concepts of liberty and due process. Botli the United States and California Constitutions guarantce that a person will not be deprived of liberty without "due process of law." sonal liberty is the right to be free from governinent-imposed confinement or physical restraint. ${ }^{82}$ It makes little difference whether the confinement is in a prison, a mental lospital, or anothcr locked institu-

78. One researcher has found that the average stay of adolescents in private facilities is much louger than in public ones, even though the publicly committed patients had more severe diagnoses. P. Guttridge, Psychiatric and Non-Psychiatric Factors in the Hospitalization of Adolescents (1981) (unpublished Ph.D. dissertatiou, University of Southern California). A possible explanation is that public institutions are monitored more carefully by the legal system.

79. Beyer \& Wilson, The Reluctant Volunteer: $A$ Child's Right to Resist Commitment, in G. Koocher, Children's Rights and the Mental Health Professions 133, 137 (1976).

80. See supra text accompanying notes 66-77.

81. U.S. Const. amend. XIV; CAL. Const. art 1, \$\$ 7(a), 15.

82. Meyer v. Nebraska, 262 U.S. 390, 399 (1923); see also J. Nowak, R. RotUNDA, \& J. 
tion, because in all of these situations physical freedom is drastically reduced. ${ }^{83}$ Hence, the involuntary hospitalization of an adult mental patient implicates constitutional rights. ${ }^{84}$

The involuntary commitment of a child also implicates constitutional rights. Children as well as adults are protected by the Constitution. For example, in In re Gault ${ }^{85}$ the United States Supreme Court ruled that the fourteenth amendment's due process guarantees apply im juvenile court proceedings. In Goss v. Lopez, ${ }^{86}$ the Court lield that suspension from public school imphicates constitutional interests and that due process requires that the student be afforded minimal procedural protections. Other cases have made clear that most constitutional protections apply to children. ${ }^{87}$ As discussed earlier, however, children's constitutional rights are tempered by their parents' right to direct their upbringing. ${ }^{88}$

Once a constitutional right is threatened, the law requires that procedures be instituted to prevent unfair and mistaken deprivations of the right. ${ }^{89}$ The United States Supreme Court has identified three factors that determine how much process is due: ${ }^{90}$ (1) the private imterests at stake, which in the case of the commitment of a child to a mental hos-

Young, Handbook on Constitutional Law 483 (1978) [hereinafter cited as J. Nowak]. This concept can be traced back to the Magna Carta. Id. at 483 n.4.

83. E.g., Addington v. Texas, 441 U.S. 418, 425 (1979); In re Gault, 387 U.S. 1, 27 (1967).

84. E.g., O'Connor v. Donaldson, 422 U.S. 563 (1975).

It has been argued that the stigmatization that goes with involuntary commitment to a mental hospital is also a deprivation of constitntionally protected liberty. E.g., NATIONAL JUVENILE LAW Center, Legal Challenges to the "Voluntary" Admission of Children to Mental INSTITUTIONS 81-90 (1977). There is some support in the case law for this position. See Addington v. Texas, 441 U.S. 418, 426 (1979). But see Paul v. Davis, 424 U.S. 693, 701 (1976) (interest in reputation alone not sufficient to imvoke dne process protection). So long as the patient is involuntarily hospitalized, however, the point is academic because the loss of physical liberty is sufficient to invoke constitutional safeguards.

85. 387 U.S. 1 (1967).

86. 419 U.S. 565 (1975).

87. See, e.g., Tinker v. Des Moines Indep. Community School Dist., 393 U.S. 503 (1969) (high school students have first amendinent rights).

88. See supra text accompanying notes 25-50.

89. Fuentes v. Shevin, 407 U.S. 67,97 (1972).

It has been argued that another primary purpose of procedural due process should be to afford the imdividual dignity by letting him know that he is being heard and that he is not being treated arbitrarily. L. TRIBE, AMERICAN Constitutional Law S02.03 (1978); Saphire, Specifying Due Process Values: Toward a More Responsive Approach to Procedural Protection, 127 U. PA. L. REv. 111, 114-25 (1978). A majority of the Supreme Court has never adopted "individual dignity" as a significant component of procedural due process, but the California Supreme Court has recently held that dignity will be an important consideration in the application of the due process safeguards guaranteed by the California Constitution. People v. Ramirez, 25 Cal. 3d 260, 268, 599 P.2d 622, 626, 158 Cal. Rptr. 316, 320 (1979). For a comparison of the federal and California tests, see Note, People v. Ramirez: A New Liberty Interest Expands Due Process Protections, 69 CALIF. L. Rev. 1073 (1981).

90. Mathews v. Eldridge, 424 U.S. 319, 334-35 (1976). 
pital is a combination of the interests of the child and parents; ${ }^{91}$ (2) the government's interest, which includes protection of the public as well as the financial and administrative costs involved; and (3) the risk that the procedures currently in use will result in an erroneous deprivation. ${ }^{92}$ The extent of the procedures required to protect the individual's interests will vary depending on the weight the court gives each factor.

The choice of appropriate procedures is based on the concepts of notice and a hearing. ${ }^{93}$ At the core are the right to be notified in advance of any decision, ${ }^{94}$ the right of the individual to present his side of the story to the decisionmaker, ${ }^{95}$ and the right to have one's case decided by a fair and impartial decisionmaker. ${ }^{96}$ The inore serious the deprivation, the inore likely a court is to require additional procedural rights such as an opportunity to present evidence or witnesses, a chance to confront and cross-examine unfriendly witnesses, the right to counsel, and the right to a written statement of reasons for the decision. ${ }^{97}$

The primary function of these procedural protections in the coinmitunent context is to guard against erroneous deprivations of liberty. ${ }^{98}$ As discussed earher, there is a substantial risk of error in all psychiatric judgments, including commitunent decisions. ${ }^{99}$ Given the severe deprivation of liberty that accompanies involuntary cominitinent to a mental institution, many courts and cominentators have concluded that if, on the request of parents, medical professionals have the sole authority to accept or reject cominitments, the error rate would be constitutionally intolerable. ${ }^{100}$ Hence, those concerned with the child's legal rights demand legal procedures that will minimize these risks, since it is the

91. Parham v. J.R., 442 U.S. 584, 600 (1979).

92. Under the California Constitution, the dignity of the individual is a fourth factor to be considered. People v. Ramirez, 25 Cal. 3d 260, 599 P.2d 622, 158 Cal. Rptr. 316 (1979).

93. As Justice Frankfurter has stated, "No better instrument has been devised for arriving at truth than to give a person in jeopardy of serious loss notice of the case against him and opportunity to ineet it;" these procedures also serve the function of "generating the feeling, so important to a popular government, that justice has been done." Joint Anti-Fascist Refugee Comm. v. McGrath, 341 U.S. 123, $171-72$ (1951) (Frankfurter, J., concurring). See generally Friendly, Some Kind of Hearing, 123 U. PA. L. REv. 1267 (1975).

94. E.g., Goss v. Lopez, 419 U.S. 565,579 (1975).

95. E.g., Goldberg v. Kelly, 397 U.S. 254, 267 (1970). But see Ingraham v. Wright, 430 U.S. 651 (1977) (possibility of tort suit sufficient to protect liberty interest of child who is subjected to corporal punishment in school).

96. E.g., Gibson v. Berryhill, 411 U.S. 564, 579 (1973).

97. J. NowAK, supra note 82, at 499. Compare, e.g., Morrissey v. Brewer, 408 U.S. 471, 48889 (1972) (revocation of parole) with Goss v. Lopez, 419 U.S. 565, 583 (1975) (10-day suspension of student from school).

98. Greenholtz v. Inmates of Neb. Penal \& Correctional Complex, 442 U.S. I, 13 (1979) ("the quantum and quality of the process due in a particular situation depends upon the need to serve the purpose of minimizing the risk of error").

99. See supra text accoinpanying notes 55-79.

100. See, e.g., Suzuki v. Quisenberry, 411 F. Supp. 1113,1135 (D. Hawaii 1976); In re Roger S., 19 Cal. 3d 921, 569 P.2d 1286, 141 Cal. Rptr. 298 (1977); Ellis, supra note 67. 
business of the law to protect the child's constitutional rights. ${ }^{101}$

Many inental health professionals, however, view legal procedures as counterproductive. For exainple, many believe that the candor and adversary nature of a hearing can be antitherapeutic for a sick child and that a "legal decision" that the child should be committed may stigmatize the child. ${ }^{102}$ Others suggest that public hearings threaten to expose potentially einbarrassing personal secrets to the detriment of the mimor and his family. ${ }^{103}$

Research indicates, however, that legal review can also be therapeutic for some children. ${ }^{104}$ A hearing gives a child an opportunity to express his objection to the commitment in a meaningful manner; it may crystallize the need for treatment in the eyes of the child, the family, and the mental health professionals; it may make the child feel he has been treated fairly; it affords the child some control over his destiny; and it may be a step in involving the child in planning for his care. ${ }^{105}$ A hearing may also serve to impress upon the child and his family that the child's commitment is being given careful consideration and is not being treated lightly.

Flexible procedures and skillful hearing officers can ameliorate, to some extent, the antitherapeutic effects of legal review. Relaxing formal and technical legal rules and giving the hearing officer or judge broad discretion to control all aspects of the hearing should minimize the harsher adversarial aspects of hotly contested legal proceedings. A sensitive and skilled learing officer can conduct the hearing in a manner that will allow all parties to be heard while minimizing those adversarial aspects that may be detrimental to the child or family. ${ }^{106}$

Another objection to legal procedures is that the precommitment hearings will inevitably delay treatınent or even deprive some sick children of treatment by screening thein out completely. ${ }^{107}$ Excessively

101. See, e.g., W. Bromberg, The Uses of Psychiatry IN the Law 287-88 (1979); Dershowitz, supra note 67 , at 31 .

102. H. Davidson, Forensic Psychiatry 282 (2d ed. 1965); K. Miller, Managing MadNESS 95 (1976); Silverstein, Civil Commitment of Minors: Due and Undue Process, 58 N.C.L. REv. $1133,1154-56$ (1980).

103. See infra text accompanying note 378 .

104. Meisel \& Roth, The Child's Right to Object to Hospitalization: Some Empirical Data, 4 J. PsYChIATRY \& L. 377, 384-85 (1976).

105. Id. The reasons that due process may be therapeutic for some children are similar to the reasons why it furthers the interest of individual dignity. See supra note 89.

106. In some cases the antitherapeutic effects of a hearing may still outweigh the therapeutic effects. To the extent that this occurs, it is a price that is paid for the other benefits of providing legal review of commitment decisions.

107. K. MiLLER, supra note 102, at 94, 95; Meisel \& Roth, supra note 104, at 378-79; S. Wasserinan, Impact of Patients' Rights Legislation on a Child/Adolescent Psychiatric Inpatient Unit 11 (1980) (nnanuscript on file with the California Law Review); transcript of interview with Shirley Reese, chief clinical social worker, Langley Porter Institute, at 6 (San Francisco, Cal., Feb. 17, 1981) (on file with the California Law Review). 
time-consuming procedures will delay the beginning of any treatment, especially if complex materials or a large number of witnesses must be assembled for a hearing. To avoid this problem, the hearing could be informal and flexible so that it can be responsive to all participants' needs and as short as possible-for example, nornal trial rules of evidence could be relaxed to streamline the process.

A more difficult problem is to specify a workable commitment standard. Denial of needed treatnient to a child might occur where the review process is based on a standard inappropriate for evaluating the initial medical decision. If the standard is too rigid, a minor who very much needs institutional treatment could be screened out of the cominitment process. On the other hand, too loose a standard might turn the hearimg into a meaningless exercise, since the decisionmaker would have no criteria with which to test the inedical evaluation.

The standard should address two important questions: (1) does the minor need treatment for a mental illness? and (2) is treatment in a locked facility necessary? Asking the first question tests the accuracy of the psychiatric expert's diagnosis. Asking the second question serves to protect the child's liberty interests, since it suggests that the child should be placed in the least restrictive prograin available. The standard chosen by the Roger $S$. court-is the child likely to benefit from treatment?-can be interpreted as involving both of these questions. ${ }^{108}$

Finally, soine mental health professionals question the coinpetence of lawyers and judges to evaluate the medical factors in a commitment decision. ${ }^{109}$ A proponent of the parental-medical approach to cominitment could acknowledge the uncertainty associated with psychiatric diagnoses and still argue that no one else is in a better position to evaluate that risk. ${ }^{110}$ A properly conducted hearing, however, can serve to facilitate medical judgments without substituting judges' assessments for those of psychiatrists. First, a hearing may help to resolve disputed factual issues on which the inedical evaluation is based. Second, the existence of review itself may increase the accuracy of psychological evaluations, since the reasons for thein will have to be defended in a legal forum. ${ }^{111}$ Third, a hearing provides a framework for resolving conflictimg medical assessments by bringing all the viewpoints

108. See infra note 230 and text accompanying notes $227-31$.

109. Transcript of interview with Richard Graham, M.D., Napa children's program director, at 3 (Napa, Cal., Feb. 19, 1981) (on file with the California Law Review); see also H. DAvidson, supra note 102, at 274; K. MILLER, supra note 102, at 95.

110. But see Ennis \& Litwack, supra note 58, at 734-43 (arguing that psychiatric and psychological judgments are so unrehiable that they should not be considered in legal proceedings).

111. Beyer \& Wilson, supra note 79, at 133-34; Ellis, supra note 67, at 864-65, 868; cf. M. EISEnBerg, The Structure of the CoRporation 158 (1976) ("the mere expectation that review [by a corporation's directors] is required before a plan can become effective probably heightens the rationality of the decision process by inducing extra care in the preparation of proposals"). 
and evidence together. Hence, the existence of review will ensure that medical assessments will be thorough and careful. This will tend to curb any tendency to overdiagnose.

The legal perspective and the medical perspective view the commitment of children in fundamentally different, although not necessarily mutually exclusive, ways. Where those concerned with the child's legal rights see a child with constitutional rights that need protection, the medical professionals see a mentally sick child who needs treatment. These two perspectives have fundamentally opposite premises. The legal perspective arises out of a model that assumes people are innocent, which in the commitment context translates into an assumption of samity. Medical professionals, on the other hand, are trained to assume illness in doubtful cases so that a potentially sick patient will not go untreated. ${ }^{112}$ "Just as it is a serious error for an innocent person to be convicted, so is it a serious issue for a physician to fail to detect pathology when it is present."113 Further complicating the matter of how to commit children involuntarily is the role of parents, who traditionally have authority to make all decisions concerning their children's welfare. The differences between these perspectives can be seen in the various approaches to the commitment of children adopted by litigants, courts, and the legislature. The next Part discusses the basic statutory structure for commitment of the mentally ill in California.

II

\section{California Commitment Procedures}

The procedures for civil commitment of both adults and minors in California reflect the interplay among the theoretical perspectives discussed in Part I and in fact reflect a conscious attempt to incorporate elements of both the legal and medical models into a balanced approach. Section A of this Part discusses the general civil commitment statutes under LPS; Section B discusses specialized procedures for minors; and Section $\mathrm{C}$ discusses the admissions standards of the state hospitals.

Traditionally, mental health "care" in California consisted of incarceratimg mental patients in state-operated institutions for indeterminate commitments and relieving them of most of their legal rights with only a remote possibility of ever being released. ${ }^{114}$ In the mid-1950's, a trend away from the use of state hospitals began with the growing

112. K. MLLER, supra note 102, at 94.

113. Id

114. California Health and Welfare Agency, Old Problems, New Directions 2 (proposed 1978-79 budget augmentation for mental health) (on file with the California Law Review) [hereinafter cited as Old Problems, New Directions]. 
availability of psychotropic drugs ${ }^{115}$ and the passage of the ShortDoyle Act, a statewide funding program that is an incentive for development of community mental health programs. ${ }^{116}$ In 1955, California's state hospital systein had a population of 36,000 patients. By 1977 , this number had decreased to $6,000 .{ }^{117}$

\section{A. The Lanterman-Petris-Short Act}

This dramatic population reduction was encouraged by the adoption in 1967 of the Lanternian-Petris-Short Act (LPS), ${ }^{118}$ a total revision of the law of civil commitment that reflected both the demand for increased legal rights for mental patients and growing optimism about the advances in psychotropic drugs. Its purposes were to provide quick access to mental health care for those in acute need, to provide prompt evaluation and treatment, and to stabilize patients for community reentry. ${ }^{119}$ The new drugs seemed at the time to promise a solution to severe psychotic episodes, and the legislative scheine reflects the expectation that a patient stabilized by medication would thereafter cooperate in further treatment. To accomphish these purposes, LPS created a structure of escalating levels of care from a 72-hour einergency detamment to long term commitment in a mental hospital under conservatorship. Here the legal model asserted its influence, with guaran-

115. In 1955, the legislature earmarked funds for extensive nse of psychotropic drugs in the state hospital system. Id. at 4 \& n.3.

116. Id. at 4-16. The Community Mental Health Services Act of 1957, better known as the Short-Doyle Act, CAL. WeLF. \& INST. CODE $\$ \S 5600-5803$ (West 1972 \& Supp. 1981), instituted a cost-sharing formula for community inental health programs. The original formula provided a 50-50 sphit between state and local funds for community care, with the state paying $100 \%$ of the cost of the state hospital. In order to increase the incentive to local entities to provide community programs, that balance was changed in 1964 to a $75 \%$ state and $25 \%$ county balance. In 1967, the sphit was revised to $90 \%$ state and $10 \%$ local.

Currently, the counties also contribute $10 \%$ to state hospital care, so all incentive to institutionalize is removed. An additional dismcentive to state hospitalization has also been created in the allocation of "patient days" to each county. The Department of Mental Health assigns each county an annual patient-days allocation. If, by excess referrals, the county exceeds that allotment, the state is no longer obligated to pay any hospital costs. No county has ever been charged, but it is a sanction that is used in negotiations with the state. When a county's patient days run out, the state may agree to allow more use this year in exchange for a promise of reduction in state hospital use next year. Transcript of interview with William L. Spicer, M.D., Napa staff psychiatrist and former children's program director, at 4 (Napa, Cal., Mar. 12, 1981) (on file with the California Law Revlew).

117. Old Probleins, New Directions, supra note 114, at 3.

118. 1967 Cal. Stat. ch. $1667, \S 36$, pt. 1 (amended version currently codified at CAL. WeLF. \& INST. CODE $\$ \$ 5000-5466$ (West 1972 \& Supp. 1981)). LPS went into effect in 1969 and has undergone only mimor amendments in the intervening years. Unless noted in the text, this discussion will present LPS as currently codified.

119. Thorn v. Superior Court, I Cal. 3d 666, 668, 464 P.2d 56, 57, 83 Cal. Rptr. 600, 601 (1970); CAL. Welf. \& INST. CODE $§ 5001$ (West Supp. 1981); Department of Mental Health, After a Decade of LPS-Uncertain Times in Mental Health Law $108 \mathrm{n} .11$ (Feb. 1981) (on file with the California Law Review). 
tees of judicial review for the commitment decision and full legal protections before liberty could be infringed for any significant time.

The shortest commitment period under LPS is the 72-hour hold. Any person can be detained in a psychiatric treatment facility for a 72hour period if there is probable cause to believe that, as a result of a mental disorder, he is a danger to himself or others or is gravely disabled. ${ }^{120}$ A peace officer, treatment facility staff member, or other county-designated professional may authorize such detainment. ${ }^{121} \mathrm{~A}$ court may also order a 72-liour hold, either upon the petition of another or upon the court's own motion. ${ }^{122}$

At the end of the 72-hour period, if the patient refuses further voluntary hospitalization, he must either be released or certified for involuntary commitment for fourteen days of intensive treatment. ${ }^{123}$ The patient must be notified of the certification, which must be signed by two mental health professionals and filed in superior court. ${ }^{124}$ Under the statute, the patient is entitled to a habeas corpus hearing within two days of filing a petition opposing certification. ${ }^{125}$ In Doe v. Gallinot, ${ }^{126}$ however, a federal district court ruled that a hearing must be held whether or not the patient indicates a desire for release. Thus, all patients, not just those wlio demand their rights, are assured judicial review of the inedical decision.

A person who is "imminently dangerous" can be detained for a 90 day "post-certification" period. This means he must have threatened, attempted, or inflicted harm on another before or after being placed in custody and that he continues to present an imminent threat of substantial physical harin to others. ${ }^{127}$ The patient being considered for

120. CAL. Welf. \& INST. CODE $\$ 5$ I50 (West Supp. 1981). LPS does define "gravely disabled." See infra text accompanying notes 133-34. Nowhere does the statute define the term "mental disorder."

121. Cal. Welf. \& Inst. Code $\S 5150$ (West Supp. 1981).

122. Id. $\$ \$ 5200,5201$ (West 1972).

123. Id $\$ \S 5152,5250$. A suicidal person may be certified for an additional 14 days. Id. $\$ 5260$. Section 5152 provides that the step of certification can be skipped and conservatorship can be instituted immediately. See infra text accompanying notes 129-32.

124. Id. $\S \S 5251,5253$ (West Supp. 1981). The form for notice of certification is set forth at id. $\S 5252$ (West 1972).

125. Id. $\S \S 5275-5276$.

126. 486 F. Supp. 983 (C.D. Cal. 1979), affd, 657 F.2d 1017 (9th Cir. 1981). The court noted that a patient who petitions for a writ of habeas corpus on the same day he receives notice of certification will at a minimum be detained against his will for five days-three days under $\$ 5150$ and then two days until the hearing. $486 \mathrm{~F}$. Supp. at 986 . The court ruled that hearings should in no event occur later than the seventh day of confinement. Id. at 994.

127. CAL. Welf. \& INST. CODE $\$ 5300$ (West 1972).

A legislative study prepared in early 1981 and surveying 22 inental health facilities found that there was "minimal use" made of the 90-day post-certification procedures. It was used only once in a sample of 231 patients, and reportedly used on only 81 patients statewide during fiscal 197879. California State Department of Mental Health, Evaluation of Involuntary Care and Treat- 
post-certification detention also has the right to a jury trial on the issue of the need for commitment. ${ }^{128}$

Once these relatively short term solutions have been exhausted, the patient who needs intensive long term treatinent may be a candidate for conservatorship, which is designed to provide long term "individualized treatment, supervision and placement." 129 The decision to appoimt a conservator must be based on proof beyond a reasonable doubt ${ }^{130}$ and be made by a unanimous jury, if a jury has been requested. ${ }^{131}$ The substantive standard applied is whether the patient is "gravely disabled." 132 LPS origmally defined "gravely disabled" as "[a] condition in which a person, as a result of a mental disorder, is unable to provide for his basic personal needs for food, clothing or shelter." 133 After Roger $S$, when conservatorship became the najor vehicle for commitment of minors, the legislature added a second definition to the statute: "A gravely disabled minor is a minor who, as a result of a mental disorder, is unable to use the elenents of life which are essential to liealth, safety, and development, including food, clothing, and shelter, even though provided to the minor by others." 134

The court may deprive the conservatee of many basic rights, including the right to drive, to contract, to vote, and to refuse treatnient for either the niental disorder leadimg to the conservatorship or any other medical condition not requiring surgery. ${ }^{135}$ Conservators may authorize placement of the conservatee in a inedical, psychiatric, or nursing facility and inay also authorize any medical treatment except surgery. ${ }^{136}$ The conservator has exclusive power to remove the patient from the facility, regardless of the patient's wishes. The conservator must, however, place the conservatee in the least restrictive environ-

ment Under the Lanterman-Petris-Short Act 36 (Jan. 24, 1981) (on file with the California Law Review).

128. Cal. Welf. \& INST. Code $\S 5302$ (West 1972).

129. Id. $\S 5350$ (West Supp. 1981).

130. Conservatorship of Roulet, 23 Cal. 3d 219, 590 P.2d 1, 152 Cal. Rptr. 425 (1979).

131. Cal. Welf. \& INST. Code $\S 5350$ (West Supp. 1981).

132. Id.

133. Id. $\S 5008(\mathrm{~h})$ (West 1972) (current version in West Supp. 1981).

134. Id. $\S 5350$ (West Supp. 198I). The change was motivated by a concern that virtually all children could technically be adjudicated gravely disabled under the original LPS definition because of their mability to provide for their own food, clothing, and shelter. Courts might find that result so troublesome that they would not apply that standard at all until a child's condition had severely deteriorated. The new standard was intended to enable a court to determine whether to commit a nonconsenting child on the basis of the condition and needs of the child, not on the desires of the pareuts. Telephone interview with Leona Egeland, chief deputy director for child health and intergovernmental relations, California State Department of Health Services (Aug. 13, 1981).

135. CAL. Welf. \& INST. CODE $§ 5357$ (West Supp. 1981).

136. Id. $\$ 5358$. 
ment possible. ${ }^{137}$

Conservatorship automatically terminates after one year unless renewed by the court. ${ }^{138}$ The conservatee may petition for rehearing on his status at any time but may renew the petition only once every six months thereafter. ${ }^{139}$

As a whole, therefore, LPS allows mental health professionals to make the primary decisions and recommendations regarding treatment of their patients, balanced by legal checks that increase as the term of commitment lengthens. The inore severe the infringement on personal liberty, the less autonomy is given to the inedical decisionmakers. While the decision to hold a patient for 72-hour evaluation can be made solely by medical professionals, and the medical dccision to certify a patient for 14-day imtensive treatment is subject only to after-thefact judicial review, long term treatment through conservatorship may not be undertaken without the prior consent of the court, with the opportunity for the patient to challenge the recommendation before a jury. The balance between the medical and legal models in this lcgislative scheme is designed to result in immediate attention to patient needs while protecting individual rights.

\section{B. Institutionalization of Minors}

Although the broad language of LPS as originally drafted did not exclude mimors from its protections, it unade no special provision for them. LPS procedures were not generally used for minors, since other statutory provisions made it easier and simpler to institutionalize them without regard to due process rights. ${ }^{140}$ In the years simce LPS was enacted, however, the California Supreme Court has extended the due process rights of mimors, increasing rehance on LPS as a vehicle for hospitalization. ${ }^{141}$

California's legislative scheme for institutionalization of juveniles was based originally on the proposition that care for children was the responsibility of parents. Welfare and Institutions Code section 6000 (b) gave parents the general right to sign a child into the state hospital. The legislature authorized interference with parental autonoiny only where unusual circumstances justified such a step, as in cases involving emancipated minors and wards of the court.

An emancipated minor is an adolescent who has been freed from

137. Id.

138. Id. $\$ 5361$.

139. Id. $\& 5364$.

140. E.g., id. $\$ 6000$.

141. In re Roger S., 19 Cal. 3d 921, 569 P.2d 1286, 141 Cal. Rptr. 298 (1977); In re Michael E., 15 Cal. 3d 183, 538 P.2d 331, 123 Cal. Rptr. 103 (1975). 
his parents' legal control. ${ }^{142} \mathrm{He}$ is treated as an adult for purposes of commitment and consent to psychiatric treatment. ${ }^{143}$ Less drastic intrusions on the parent-child relationship are the wardship proceedings which bring children within the jurisdiction and protection of the juvenile court. The three categories of wards include the dependent child of the court, ${ }^{144}$ the delinquent ward, ${ }^{145}$ and the ward who has committed a crime. ${ }^{146}$

The dependent child of the court is a catch-all category that is used broadly as a means of protecting children from neglectful or abusive parents. ${ }^{147}$ A delinquent ward, commonly called a "status offender," is a minor who is guilty of infractions that exist only because he is a minor rather than an adult. These include refusal to obey the orders of parents or school authorities, habitual truancy, or frequent curfew violations. ${ }^{148}$ Finally, a juvenile who has been convicted of a crime is also judged to be a ward of the court. ${ }^{149}$

142. A parent may voluntarily relinquish the right to control the minor. CAL. Crv. CodE $\S 211$ (West 1954). The state may bring an action to free the child from parental authority upon abuse of that authority by the parent. Id. $\S 203$. In 1978, the Emancipation of Minors Act was added to the Civil Code, providing for emancipation upon the minor's marriage, active duty in the armed forces, or declaration by the superior court. A minor may petition for emancipation if he is (1) willingly living apart from his parents with the parents' consent or acquiescence, (2) at least 14 years old, (3) managing his own financial affairs, and (4) not living by criminal activity. The court will grant the minor's petition if it finds that emancipation would not be contrary to the minor's best interests. Id. $\$ \$ 60-70$ (West Supp. 1981).

143. Id. $\S 63(a)$. It seems clear that this category will have little impact on commitment. An emancipated minor could not come within CAL. WELF. \& INST. CoDE § 6000 (West Supp. 1981) because the parents have lost authority to authorize treatment. Under LPS, the minor can only be committed if he is found gravely disabled.

144. CAL. Welf. \& INST. CODE $\S 300$ (West Supp. 1981).

145. Id. $\$ 601$.

146. Id. $\$ 602$.

147. A child may be considered for dependency

(a) who is in need of proper and effective parental care or control and who has no parent or guardian willing, capable, or actnally exercising control,

(b) who is destitute, not provided with the necessities of life or with a home;

(c) who is physically dangerous to the public because of a mental or physical deficiency, disorder or abnornality;

(d) whose home is unfit because of neglect, cruelty, depravity, or physical abuse. Id. $\S 300$.

148. Id. $\$ 601$. Before 1975 , this category also included "in danger of leading an idle, dissolute, lewd or immoral life" and allowed placement of these children in locked correctional facilities with others who had actually committed crimes. Sharp criticism of these provisions led to their deletion. 6 B. WITKIN, Summary OF California Law $\$ 279$ (Supp. 1980).

149. Such a juvenile may be sentenced to a local correctional facility upon conviction. CAL. WELF. \& INST. CODE $\S 730$ (West Supp. 1981). If he is accepted for admission to a correctional facility of the California Yonth Authority, and the Yonth Authority determines that treatment would be expedited by transfer to the state hospital, the director of the Youth Authority can certify the ward for admission to the state hospital. Id. \$ 1756. If the ward is deemed unable to stand trial for the crime, he inay be sent to the state hospital until he is competent to do so. CAL. PEnal Code $\$ 1370$ (West Supp. 198I). If he is judged insane at the time the crime was committed and has not yet recovered, the court can direct his commitment to the state hospital. Cal. Welf. \& INST. CODE § 702.3 (West Supp. 1981). 
Before 1975, the juvenile court could commit any juvenile ward it determined was mentally disordered to a state hospital as a "voluntary" patient. ${ }^{150}$ The California Supreme Court held in In re Michael E. however, that the juvenile court can commit wards only in accordance with LPS. ${ }^{151}$ If the juvenile court suspects that a ward is mentally disordered, the court can order 72-hour involuntary confinement for observation and evaluation. ${ }^{152}$ After that, LPS guarantees apply, and only if the ward is gravely disabled and therefore subject to conservatorship can he be committed to a state hospital for long terni care. ${ }^{153}$ Shortly after Michael $E$. was decided, section 6552 was added to the California Welfare and Institutions Code, allowing a ward to volunteer for treatınent upon the advice of counsel, while retaining the right to be released from the treatment facility and returned to the juvenile court jurisdiction upon demand. ${ }^{154}$

As section $6000($ b) was applied to Roger and to other ininors still under parental control, the major protection against inappropriate commitment was the screening process that existed at the state and county levels. ${ }^{155}$ A child coining into the county inental health systein might pass through a wide range of treatment alternatives before hospitalization was considered. Roger himself had been in foster homes and an adolescent group home before transfer to Napa State Hospital. ${ }^{156}$ Once it was determined that no local facilities could provide adequate placement for a child, an authorized county mental health worker would contact state hospital personnel to describe the clinical situation and discuss the possibility of admission. Only if the admissions personnel agreed could a child be transferred to one of the two state hospitals in California that accept children-Napa in the north and Camarillo in the south. ${ }^{157}$

\section{Admission to the State Hospital}

Children with severe emotional or behavioral problems-both those with regressive psychotic disorders and those with aggressive "acting out" behaviors - who have been unable to benefit from less in-

150. See In re Michael E., 15 Cal. 3d 183, 186-88, 538 P.2d 231, 232-34, 123 Cal. Rptr. 103, 104-06 (1975).

151. Id. at 189,538 P.2d at 234-35, 123 Cal. Rptr. at 106-07.

152. CAL. Welf. \& INST. CODE $\$ \S 6550-6551$ (West 1972 \& Supp. 1981).

153. In re Michael E., 15 Cal. 3d at 192-93, 538 P.2d at 237, 123 Cal. Rptr. at 108-09; see supra text accompanying notes 120-22.

154. Cal. Welf. \& INST. CODE $\S 6552$ (West Supp. 1981).

155. See id. \& 5651(f): "No mentally disordered person shall be admitted to a state hospital prior to screening and referral by an agency designated by the county Short-Doyle plan [see supra note 116] to provide this service."

156. Petition for Writ, supra note 1, at 2; Hendon transcript, supra note 3, at 2.

157. In re Roger S., 19 Cal. 3d at 932, 569 P.2d at 1292, 141 Cal. Rptr. at 304. 
tensive treatinent in the local community or who need a locked setting for the protection of theinselves or others, nay be considered for admission to the state hospital. ${ }^{158}$ Children with combined entotional and physical problems are often not accepted at private facilities, ${ }^{159}$ and consequently they can only receive treatment at a state hospital. The state hospitals can draw from a wide area to create a large enough patient pool to provide very specialized treatment for unusual problems. ${ }^{160}$

\section{Camarillo State Hospital}

Camarillo State Hospital has both an adolescent treatment program and a children's center. The two prograins differ soinewhat in focus and in the age groups of the patient populations.

The adolescent program can accommodate eighty-six patients, fifteen through seventeen years of age. ${ }^{161}$ Three units provide separate facilities for patients with different problems. Unit 15 provides long term treatment to adolescents diagnosed as having psychotic or severe neurotic reactions or orgamic impairment. Unit 17 handles nonpsychotic "acting out" patients who are likely to have histories of running away, assaultive or other criminal behavior, suicide atteinpts, incorrigibility, and previous failed placeinents. "In addition, these adolescents may show difficulty in relating to authority and to their peers, may display negativism, and may lack overt notivation for personal change." 162 Unit 65 also treats nonpsychotic patients. Its patients need mpatient therapy but would not be able to cope in the Unit 17 treatment program because they are not as aggressive as their peers.

The Camarillo adolescent prograin is designed to provide a "constantly predictable environinent"163 that helps restrueture internal equilibrium and reduce inaladaptive behaviors. Treatnient techniques mclude milieu therapy, individual and group therapy, and family counseling. Psychotropic nuedication may be administered to Unit 65

158. See Camarillo State Hospital, Adolescent Treatment Program (June 1979 program description) (on file with the California Law Review) [hereinafter cited as Camarillo Adolescent Program Description].

159. Graham transcript, supra note 109, at 1; transcript of interview with James Sorrells, Ph.D., case management speciahist, Alameda County Mental Health Services, at 6 (Oakland, Cal., Mar. 3, 1981) (on file with the California Law Review).

160. For example, Napa has a unit specializing in the treatment of mentally disturbed children with hearing impairments, where therapy is conducted in sign language. Napa Children's Program (undated program description) (on file with the California Law Review).

161. See Camarillo Adolescent Program Description, supra note 158, at 5; letter from Henry L. Marshall, Camarillo adolescent admissions coordinator, to Carol Dillon and Margaret Roisman (Jan. 26, 1982) (on file with the California Law Review). The textual information that follows is drawn from the description.

162. Camarillo Adolescent Program Description, supra note 158, at 6.

163. Id. at 8 . 
and 15 patients, and mechamical restraint may be used for teinporary behavior control.

The Camarillo children's treatment center admits up to ninety-six children, ages five to fifteen. ${ }^{164}$ The basic admission criterion is the presence of a serious emotional or behavioral problem. Patients may be either withdrawn or aggressive; approximately eighty-five percent have a history of violent behavior and about ten percent have a history of seizures. Many have learning disabilities, perceptual motor probleins, or neurological handicaps. Treatment programs are highly individualized, taking into account the different needs of very young children to learn basic self-care or of pre-adolescents to learn to handle peer relationships and authority. Where the focus of the adolescent program is on reinforcing inadequate self-control systems, the children's program tries to provide a family-like atmosphere that fulfills a child's need for security and protection. Individual and group psychotherapy and family counseling where possible are the predominant therapy techniques.

\section{Napa State Hospital}

Napa State Hospital has the same dual program structure for minors-a children's program and an adolescent program. The two programs are philosophically very different, and mental state, not chronological age, is the basic criterion for admission.

The Napa children's program admits einotionally disturbed children and adolescents up to age sixteen. It takes children who are "grossly psychotic" and "functionally regressed," many of whom would clearly fit within the LPS definition of gravely disabled. ${ }^{165}$ The patients tend to have developmental problems and the focus of the program is "reparenting and nurturing." 166 Many of the patients in this program have multiple disabilities that increase the difficulty of treatment, mcluding mental retardation, neurological handicaps, autism,

164. The textual information that follows is drawn from Camarillo State Hospital, Children's Treatment Center (undated program description) (on file with the California Law Review).

165. Transcript of interview with Fred Hollander, Napa adolescent program director, at 2 (Napa, Cal., Feb. 19, 1981) (on file with the California Law Review). Hollander made these remarks in comparing the children's program to the adolescent program.

166. Transcript of interview with Allen J. Full, Jr., Napa adolescent program assistant program director and referral coordimator, at 3 (Napa, Cal., Mar. 12, 1981) (on file with the California Law Review). Richard Graham, M.D., director of the Napa children's program, compared the adolescent and children's programs as follows:

The difference between us and the adolescent program is that the kids that we see are more regressed, more in need of a nurturing kind of program and less in need of peer relationships or at least the degree of peer pressure, because they are more regressed or more psychotic or have other problems.

Graham transcript, supra note 109 , at 1. 
and medical disorders. ${ }^{167}$ An adolescent might be routed to this program if he were so immature that he could not compete with his peers in the more intense adolescent program. ${ }^{168}$

The Napa adolescent program is a "psychiatrically based military school" that uses peer pressure and a tightly structured environment as its major therapy techniques. ${ }^{169}$ The program consists of three locked wards, two of which house the bulk of the patient population and a third unit that houses those who are developmentally less mature than the others. A fourth branch of the treatment scheme is the community reentry program, a day treatment unit that accommodates between twelve and eighteen patients who are being readied to leave Napa. A separate "satellite" facility located on the Napa grounds but apart from the rest of the hospital serves as a point of departure back to parents or community placement. ${ }^{170}$

Roger was apparently typical of the adolescents likely to be admitted to Napa's adolescent program. The program population ranges in age from twelve to eighteen, although most are older than fourteen. The typical patient is a chronic runaway who has had multiple placement failures or rejections, who was abused as a child, or who im turn abuses other children or his parents. ${ }^{171}$ While the population is drawn from all socioeconomic backgrounds, the vast majority are Caucasian. ${ }^{172}$ Males outnumber females two to one. The patients often have a history of drug and alcohol abuse and juvenile court involvement; some female adolescents have been sexually "acting out" in a way the family or community will not tolerate. ${ }^{173}$

The locked ward was apparently a severe shock to Roger. He complained of being placed with other patients so severely disturbed that they were unable to dress themselves. Allegedly, two suicide attempts occurred during the first few inonths he was institutionalized, and he claimed to be fearful of sexual assault after being approached

167. Full transcript, supra note 166, at 3; Hollander transcript, supra note 165, at 2 . Some patients may be admitted to the adolescent program, and then when it becomes apparent that they cannot succeed in that setting, they may be transferred to the children's program. The adolescent program also maintains its own separate unit for patients who do not belong in the children's program but who are enough behind their peers developmentally that they are unable to contend with the peer pressure structure. Id. at 1 .

168. Hollander transcript, supra note 165 , at 1 .

169. Full transcript, supra note 166 , at 3.

170. Hollander transcript, supra note 165 , at 1.

171. Full transcript, supra note 166 , at 4.

172. One source who asked not to be identified speculated that some mimority communities are more tolerant of violent acting out behavior than, for example, small rural towns. Also, there is a suspicion of institutions, and in some populations, like the Asian, there is a strong extended family that copes with problems from within.

173. Full transcript, supra note 166 , at 4. 
sexually by other boys. ${ }^{174}$ His letter of complaint to the pubhic defender's office began the hitigation that resulted in the California Supreme Court's Roger $S$. decision. ${ }^{175}$

\section{III}

\section{THE ROGER $S$. DECISION}

The issues posed by Roger's case trapped the California Supreme Court between its deep distrust of what it had elsewhere called "the guesses of doctors hired by the state" 176 and the longstanding judicial endorseinent of family autonomy. Section 6000(b)'s provisions for commitınent of minors relied on parental decisions as screened by mental health professionals. If this procedure did not meet constitutional standards, a new commitinent procedure would have to be found.

Several avenues were open to the court. It could have agreed with Roger's attorneys that adolescents could only be committed involuntarily according to LPS procedures-i.e., by conservatorship. ${ }^{177}$ This would require the parents' decision to be screened by a judge and jury, rather than by the state hospital staff psychiatrist as required by section 6000 (b). Alternatively, the court could have required that the conclusion of the parents and the doctor be screened less formally by some third party, such as a patient advocate, without the procedural trappings of a conservatorship hearing. Finally, section 6000(b)'s commitment standard-"suitable ... for care and treatment in [a state inental] hospital" 178 - could have been altered. Given its suspicion of the accuracy of psychiatric judgments, the court was unlikely to agree with the attorney general that the proper standard was the admitting physician's best clinical judgment. ${ }^{179}$ The court could have made the medical commitment standard more stringent, however, by adopting a behavioral test-for instance, a version of the LPS "gravely disabled" standard tailored to adolescents. ${ }^{180}$

In its eventual opinion, ${ }^{181}$ the court struck down section 6000 (b) as

174. Petition for Writ, supra note I, at 5.

175. By the time Roger's demand for release was presented to the court, the medical evaluation of his condition was that he "has maintained for several months without aggressive, destructive acts and as we beheve he has plateaued out-i.e., is not gaining further benefit from hospitalization, we believe he should be placed in an appropriate community facility." Brief for Respondent, supra note 3, Appendix A.

176. People v. Burnick, 14 Cal. 3d 306, 330, 535 P.2d 352, 368, 121 Cal. Rptr. 488, 504 (1975).

177. See Petition for Writ, supra note 1. For a description of the conservatorship procedures, see supra text accoinpanying notes 129-39.

178. CAL. Welf. \& INST. CODE $§ 6000$ (West 1972) (current version at Supp. 1981).

179. See Brief for Respondent, supra note 3.

180. See supra note 134 and accompanying text.

181. 19 Cal. 3d 921, 569 P.2d 1286, 141 Cal. Rptr. 298 (1977). For a detailed analysis of the 
applied to adolescents fourteen and older, holding that due process required a different screening party and more formal screening procedures than the statute provided. Einphasizing the factual disputes in Roger's case, the court endorsed the adversarial hearing as the method for resolving such diagnostic disputes. The court stopped short of full acceptance of the children's rights approach, however. It attempted to accommodate parental interests by adopting a less fornal screening procedure than that required for conservatorship. Moreover, the court's new commitment standard for parentally committed minors seeins to require the screening party to inake a medical prediction, rather than the behavioral judgment necessary for conservatorship.

This Part of the Comment suminarizes the court's opinion. It then points out key questions the court did not answer-questions that would later create practical probleins for state and county mental health workers and the adolescents they were trying to help.

\section{A. The Opinion}

The court found that three constitutionally protected interests were involved in the commitment decision: ${ }^{182}$ the minor's interest im personal hberty, ${ }^{183}$ the parent's right to "direct the upbringing and education of children," 184 and the state's "interest in the future development of the child, $m$ avoiding diagnosis and/or commitinent based on erroneous information and evaluation thereof, and in assuring the child fair treatinent."185 The court concluded that even though the minor's personal hiberty was limited by his parents' rights, the minor had a protected right to due process in commitment because of the significant potential for diagnostic errors and the serious consequences of involuntary commitment. ${ }^{186}$ Section 6000 (b) violated this right.

Due process, the court held, required that the parental decision be screened. The minor was entitled to a precommitment hearing. ${ }^{187} \mathrm{He}$ had the right to receive adequate written notice of the basis for the proposed action and to be present at the hearing, as well as to present

case, see Note, The Involuntary Commitment of Minors: Where to Draw the Line on Parental Authority, 66 CALIF. L. REv. 344 (1978).

182. The majority grounded its decision on the due process clauses of both the United States Constitution, U.S. CoNST. amend. XIV, § 2, and the California Constitution, CAL. CoNST. art. I, \$ 7(a). 19 Cal. 3d at 927, 569 P.2d at 1289, 141 Cal. Rptr. at 301. Justices Richardson and Clark criticized this dual rehance because it "insulates [the court's] decisions both from review by the United States Supreme Court and from change through the legislative or initiative process." 19 Cal. 3d at 947, 569 P.2d at 1302, 141 Cal. Rptr. at 314 (Richardson, J., concurring and dissenting).

183. 19 Cal. 3d at 927-28, 569 P.2d at 1289-90, 141 Cal. Rptr. at 301-02.

184. Pierce v. Society of Sisters, 268 U.S. 510, 534-35 (1925).

185. 19 Cal. 3d at 930, 569 P.2d at 1291, 141 Cal. Rptr. at 303.

186. Id. at 929, 569 P.2d at 1291, 141 Cal. Rptr. at 303.

187. Id. at 937,569 P.2d at 1296, $141 \mathrm{Cal}$. Rptr. at 308. 
evidence on his own behalf and confront and cross-examine opposing witnesses. ${ }^{188} \mathrm{He}$ was also entitled to a neutral and detached decisionmaker, findings by a preponderance of the evidence, and a record of the proceeding adequate to permit meaningful judicial or appellate review. ${ }^{189}$ Finally, counsel had to "be provided" 190 for the minor.

The screening procedures applicable to parentally cominitted minors, however, did not have to track the procedures available under LPS. The court specifically rejected the contention that a minor im parental custody was entitled to a jury trial, a judicial hearing, or findings beyond a reasonable doubt. ${ }^{191}$ The parental right of custody and control imcluded the power to initiate commitment proceedings, "whereas the rights of the child and the interests of the state [were] limited to preventing hospitalization that because unnecessary or potentially ineffective may be harmful to the physical or mental health of the child . . . ."192 While a judge, a jury, and the strict standard of proof ${ }^{193}$ had to be afforded imdividuals whom the state sought to commit, they were not necessary when parents sought to comnnt a child im their custody. ${ }^{194}$

Similarly, parental presence justified the application of a inore lenient substantive standard than that used im other imvoluntary comnntnuent schemes. LPS provided that a court could not coinmit an individual to a state hospital unless he was gravely disabled or dangerous to himself or others. ${ }^{195}$ By contrast, the court now held that parents could commit a mentally ill mimor if his behavior met the LPS standard or if it was reasonably likely that im-hospital treatment would benefit him. ${ }^{196}$ The court apparently derived this standard from the United

188. Id. at $937-38,569 \mathrm{P} .2 \mathrm{~d}$ at $1296,141 \mathrm{Cal}$. Rptr. at 308.

189. Id. at 938,569 P.2d at 1296,141 Cal. Rptr. at 308.

190. Id.

191. Id. at $938-39,569$ P.2d at 1296-97, 141 Cal. Rptr. at 308-09. But see Addington v. Texas, 441 U.S. 418 (1979) (fourteenth amendment requires clear and convimcing evidence in state imvoluntary commitment proceedings).

192. $19 \mathrm{Cal} .3 \mathrm{~d}$ at 939,569 P.2d at $1297,141 \mathrm{Cal}$. Rptr. at 309.

193. Id. The court implied that minors in parental custody were well served by the standard applied to "dependency proceedings . . . and the dispositional phase of delinquency proceedings." Id. The preponderance of the evidence is indeed sufficient to declare a minor a dependent ward of the court under CAL. WELF. \& INST. CODE $\S 601$ (West Supp. 1981). Unlike cominitinent, however, such a wardship does not lead to confinement in a closed facility. See In re Arthur N., 16 Cal. 3d 226, 237 n.13, 545 P.2d 1345, 1352 n.13, 127 Cal. Rptr. 641,648 n.13 (1976). Moreover, while the United States Supreme Court carefully noted that its adoption of the reasonable doubt standard in adjudicatory juvenile proceedings left existing dispositional procedures "unimpaired," In re Winship, 397 U.S. 358, 366 (1970), minors subject to the court's jurisdiction have already been judged guilty of wrongdomg. Minors covered by Roger $S$. are "guilty" only of being under 18 and in parental custody.

194. 19 Cal. 3d at 939,569 P.2d at 1297,141 Cal. Rptr. at 309.

195. See supra text accompanying notes 120-34.

196. 19 Cal. 3d at 927,569 P.2d at 1289, 141 Cal. Rptr. at 301. 
States Supreme Court's statement in Wisconsin v. Yoder ${ }^{197}$ that the parental right to custody and control could be invaded only if "it appears that the parental decisions will jeopardize the health or safety of the child or have a potential for sigmificant social burdens." 198 Thus, a parent-initiated commitment that was reasonably likely to benefit the child, whether the child thought so or not, could not be challenged. ${ }^{199}$

The court's commitment sclieme, however, applied only to minors over thirteen. Not only was Roger himself fourteen, thus relieving the court from any need to consider the potential rights of younger children, ${ }^{200}$ but minors of fourteen were statutorily presumed responsible for criminal acts. ${ }^{201}$ "It would be anomalous indeed," the court reasoned, "if they were not also presumed to have sufficient capacity to exercise due process rights at that age."202

Justice Clark, dissenting, argued that due process did not require the adoption of such a commitment sclieme. The minor's objections could constitutionally be heard after the minor's liberty has been curtailed. $^{203}$ Due process did not mandate counsel for the minor either. "As the questions presented in this proceeding do not involve guilt or innocence, but necessity and availability of treatment, the youngster should be assisted not by a lawyer but by a mental healtl professional from his own community having ready access to witnesses and familiarity with community resources."204

In Clark's view, the mental health professionals on the hospital

197. 406 U.S. 205 (1972).

198. Id. at 234.

199. The court's acceptance of grave disability and dangerousness as proper grounds for a child's commitment imphied that commitment in such circumstances was presumably beneficial for minors as well as for adults. Although the court did not clearly say so, its reference to the mimor's right to "a fair opportunity to establish" that he is not dangerous, gravely disabled, or likely to benefit from the proposed treatment implies that the minor bears the burden of proof. 19 Cal. 3d at 935, 569 P.2d at 1295, 141 Cal. Rptr. at 307 (emphasis added).

200. Id. at 931,569 P.2d at 1292, 141 Cal. Rptr. at 304. Children younger than fourteen can apparently still be counumitted by their parents as voluntary patients under $\$ 6000(\mathrm{~b})$.

201. Cal. Penal Code $\$ 26$ (West 1972).

202. 19 Cal. 3d at 931, 569 P.2d at 1292, 141 Cal. Rptr. at 304. Psychological research supports the court's age line. By age 14, research shows, inost children are capable of performing the five basic cognitive activities: "perception and interpretation of information, memory, generation of hypotheses or solutions to problems, evaluation of the aceuracy and appropriateness of cognitive prodncts, and deduction." P. Mussen, J. Conger \& J. KaGAN, ChILD Development AND Personality 312-14, 322 (4th ed. 1974); see B. Inhelder \& J. Piaget, The Growth of LogiCAL ThINking From ChILdHood to AdolescenCE 334-50 (1958). Thus a 14-year-old would have the intellectual capacity to understand and evaluate the proposed commitment and any available alternatives. Showalter, The Minor's Role in Consent for Mental Health Treatment, $17 \mathrm{~J}$. AM. ACad. Child Psychology 505, 510 (1978).

203. 19 Cal. 3 d at 943,569 P.2d at 1300,141 Cal. Rptr. at 311 (comparing minor's conditional liberty with that of parolee and applying standard of Morrissey v. Brewer, 408 U.S. 471 (1972)).

204. 19 Cal. 3d at 944,569 P.2d at 1300, 141 Cal. Rptr. at 312. 
staff qualify as "neutral factinders." 205 The differing pre- and postadmission evaluations in Roger's case did not demonstrate incompetence but merely a disagreement among professionals, comparable to the differences between justices on the bench. ${ }^{206}$ "[N]either judges nor administrative hearing officers are better quahified than psychiatrists to render psychiatric judgenents."207

The court's decision raised many questions for those charged with following its directives. It did not specify clearly how the new admimistrative hearing would work. It did not define which inental health facilities must comply. Its new substantive standard of benefit to the child was inherently vague. Moreover, when the court suggested the use of LPS conservatorships and waivers as interim procedures until the legislature implemented its decision, it did not realize the problems its recommendations would create for state hospitals and county mental health facilities.

205. Id. at 942,569 P.2d at 1299,141 Cal. Rptr. at 311.

206. Id.

207. Id. This comment was to be quoted approvingly by Chief Justice Burger in Parham v. J.R., 442 U.S. 584, 607 (1979), in which the Supreine Court upheld a Georgia statute allowing parents to commit a minor child to a state mental hospital with the consent of a staff physician. While Roger $S$. found psychiatric decisionmaking insufficient to resolve disputed questions of fact, Parham emphasized that doctors would provide adequate protection against possible parental abuses. See supra notes 51-54 and accompanying text.

Because Roger $S$. was grounded on the California Constitution as well as on the Federal Constitution, 19 Cal. 3d at 927, 569 P.2d at 1289, 141 Cal. Rptr. at 301, Parham probably did not overrule it. Parham could, however, have influenced later attempts to implement Roger $S$. legislatively by validating the medical approach to the coinumitment of juveniles. See infra text accompanymg notes 472-74. Nevertheless, in the commitment cases that followed Roger $S$., California courts chose the medical-legal model of Roger $S$. over the purely medical model of Parham. In Conservatorship of Roulet, 23 Cal. 3d 219, 590 P.2d 1, 152 Cal. Rptr. 424 (1979), the Cahifornia Supreme Court leeld that in a conservatorship proceeding alleging grave disabihity, the jury must be convinced unanimously and the disability must be proved beyond a reasonable doubt. These requirements were held to be appropriate even though the proceeding was civil and not criminal: "One has only to imagine the horror experienced by a coinpetent person falsely committed as mentally disturbed in order to appreciate that freedom is openly on trial at a civil commitment proceeding." Id. at 223, 590 P.2d at 3, 152 Cal. Rptr. at 427 . See also Conservatorship of Hofferber, $28 \mathrm{Cal}$. 3d 161, 616 P.2d 836, $167 \mathrm{Cal}$. Rptr. 854 (1980) (incompetent criminal defendant is eutitled to jury deternimation and proof beyond a reasonable doubt on issue of existence of dangerous mental condition before commitment); Cramer v. Tyars, 23 Cal. 3d 131, 588 P.2d 793, 151 Cal. Rptr. 653 (1979) (consequences of commitment and crimmal conviction are equivalent). The Roulet court explicitly stated that due process required a unanimous jury to counteract the uncertainty of psychiatric diagnosis, referring to diagnostic disagreements as "expert fallibihity." 23 Cal. 3d at 230, 590 P.2d at 7, 152 Cal. Rptr. at 431.

Roger $S$.'s refusal to equate social agency good intentions aud constitutional protections was echoed in In re Hop, 29 Cal. 3d 82, 623 P.2d 282, 171 Cal. Rptr. 721 (1981), where the court held that before the state could place developmentally disabled adults in a state hospital, a judicial determination of disability inust be inade. Such persons were entitled, by analogy, to the rights of LPS conservatees. Id. at 93-94, 623 P.2d at 289, 171 Cal. Rptr. at 728. 


\section{B. Problems of Implementation}

\section{The Hearing}

Although due process entitles minors to have the parental decision screened by an outside party, ${ }^{208}$ the court found conservatorship an inappropriate model for committing minors in parental custody. The court noted that parents have the right to control their child's upbringing, including the type and extent of medical and psychiatric treatment the child will receive. ${ }^{209}$ Thus, a Roger $S$. minor was not similarly situated with minors in the state's custody or with adults. Those minors and adults were entitled under LPS to a judicial hearing and a jury before the state could commit them. ${ }^{210}$ But " $[w]$ hen the parent who already has the right and obligation to control a child's personal liberty seeks, in the exercise of that right, to place the child in a mental hospital ... an administrative hearing may be adequate to satisfy due process." 211

Unfortunately, however, the court neglected to explain what it meant by an admimistrative hearing. What rules of evidence and procedure would apply? Since neitlier a judge nor a jury was required, ${ }^{212}$ who should hear the evidence and decide whether the minor should be hospitalized? Would a mental health professional not on the state hospital staff be an acceptable decisionmaker, ${ }^{213}$ or was legal training of

208. Neither the attorney general nor the dissenting justices argued that no hearing was required. Perhaps, like Justice Clark, the state's lawyers thought it was a losing argument. See 19 Cal. 3d at 941, 569 P.2d at 1298, 141 Cal. Rptr. at 310 (Clark, J., dissenting).

209. Id. at 938,569 P.2d at 1297, 141 Cal. Rptr. at 309.

210. See supra text accoinpanying notes $150-54$.

211. 19 Cal. $3 d$ at 939,569 P.2d at 1297, 141 Cal. Rptr. at 309.

212. The court reasoned that since minors had no constitutional right to a jury in juvenile court proceedings, they had no "greater right in purely civil commitment proceedings." Id. at 938 , 569 P.2d at 1297, 141 Cal. Rptr. at 309. Moreover, a Roger $S$. ninor was opposing not the state but his parents, and was thus not similarly situated with those whose coininitment was initiated by the state. "[A]bsent some basis upon which to conclude that a neutral judge or hearing officer will not offer a decision inaking process substantially equivalent to a jury trial, neither due process nor equal protection requires that this decision be by jury." Id. at 938-39, 569 P.2d at 1297, 141 Cal. Rptr. at 309. Compare the Supreme Court's description of the jury's role in the civil commitment of adults in Huinphrey v. Cady, 405 U.S. 504 (1971):

[Most states condition involuntary commitments] not solely on the medical judgment that the [imdividual] is inentally ill and treatable, but also on the social and legal judgment that his potential for doing harm, to himself or to others, is great enough to justify such a massive curtailment of liberty. In making this determination, the jury serves the critical function of introducing into the process a lay judgment, refiecting values generally leeld in the cominunity, concerning the kinds of potential harm that justify the State in confining a person for coinpulsory treatinent.

Id. at 509 (footnotes omitted).

213. The court's reliance on cases involving the revocation of adult convicts' paroles indicated that it might not require an outsider to hear the arguments, for those cases noted that due process permitted the parole board-composed of corrections professionals-to decide revocation issues. See 19 Cal. 3d at 938, 569 P.2d at 1296, 141 Cal. Rptr. at 308 (citing Gagnon v. Scarpelli, 411 U.S. 778, 790-91 (1973); Morrissey v. Brewer, 408 U.S. 471, 489 (1972)). But the court's expressed 
some sort required? If an administrative panel were to preside, how should it be composed, and who should select its members? The court had endorsed an adversarial method of dispute resolution, but it stopped short of full-scale adversary procedures without saying clearly what should take its place. ${ }^{214}$

\section{The Facilities}

The court's decision was grounded upon the principle that "[w] $[$ hen the state participates in deprivation of a person's right to personal liberty, even a conditional liberty, due process requires that the facts justifying that action be reliably established."215 Both the United States ${ }^{216}$ and California Constitutions ${ }^{217}$ apply due process restrictions only where state action can be found. State action is present when a "sufficiently close nexus" exists between the state and the challenged act. ${ }^{218}$

Simce Roger was confined in a state hospital by state employees, state action was obviously present in his case. Indeed, the court clearly stated that it only addressed the rights of adolescents confined in state hospitals for the mentally ill. ${ }^{219}$ Because the government did not dispute that it was "a significant participant" in curtailing Roger's lib-

distrust of mental health professionals, in and out of institutions, implied that an in-liouse decisionmaker might not be acceptable. See 19 Cal. 3d at 936, 569 P.2d at 1295, 141 Cal. Rptr. at 307.

214. The court did specify that the adolescent's hearing had to be held before he could be hospitalized. The range of possible hearing structures is wide. Parts IV and VI of this Coinment discuss some of the solutions proposed in the California Legislature. See infra text accompanying notes 289-345, 430-95. Part $V$ describes the diverse efforts of various counties to set up adequate screening procedures in the absence of a statewide response to Roger $S$. See infra text accompanying notes 346-429. Finally, the Conclusion outlines a suggested solution.

215. 19 Cal. 3d at 937,569 P.2d at 1296, 141 Cal. Rptr. at 308.

216. Shelley v. Kraemer, 334 U.S. 1, 13 (1948).

217. Kruger v. Wells Fargo Bank, 11 Cal. 3d 352, 366-67, 521 P.2d 441, 449-50, 113 Cal. Rptr. 449, 457-58 (1974).

218. Jackson v. Metropolitan Edison Co., 419 U.S. 345, 351 (1974).

219. 19 Cal. 3d at $927 \&$ n.3, 569 P.2d at $1289 \&$ n.3, 141 Cal. Rptr. at $301 \&$ n.3.

The supreme court's handling of the appeal of In re Jolin S., 135 Cal. Rptr. 893 (2d Dist. 1977) (official report depublished by order of California Supreme Court), sidestepped the difficult problem of intrafamily disputes involving private hospital placement. In that case, the court of appeal overturned a trial court's application of LPS procedures to a parentally committed minor who protested his placement in a private facility. The proper remedy was "substitution of new authority for parental authority that has been found defective or abusive." Id. at 902 . The minor petitioned the California Supreme Court for review. In an unpublished order, the court granted a hearing, reversed the court of appeal's decision because Jolin had turned 21 during the pendency of the appeal, rendering the case moot, and ordered the case deleted from the official reports. Hoffman, The "Due Process" Rights of Minors in Mental Hospitals, 13 U.S.F.L. REv. 63, 65 n.8 (1978) (written by counsel of record for Jolin's parents). Three months later, Roger $S$. was announced. By striking the court of appeal's defense of parental rights, but saving its own limited endorseinent of minors' due process rights for a case where the state was clearly a party, the supreme court avoided-for the moment-the difficult issue of what rights protcsting minors had against parents acting alone. 
erty, ${ }^{220}$ the court did not have to define how much state involvement triggered an adolescent's right to due process in the commitınent decision. Thus it was not clear whether the inandate of Roger $S$. extended to facilities not specifically included in the court's opinion.

It is probable, however, that Roger $S$. also apphes to commitments to private facilities where the state pays for the child's treatment under Cahfornia's Short-Doyle Act. The Short-Doyle Act ${ }^{221}$ finances inental health programs at the county level. Rather than developing new county-operatcd facilities, the Act explicitly encourages counties to contract with existimg private facilities to provide mental health services. ${ }^{222}$ Thus, under the Short-Doyle Act, some children are committed to private hospitals, known as contracting facilities, at state expense. State or county payinent for such treatment probably provides a sufficiently close nexus between the state and the commitinent to entitle those children to Roger $S$. due process rights. The Constitution will not permit the state to subsidize directly a private act that, if done by the state, would violate a constitutional right. ${ }^{223}$

When parents commit a child to a private hospital at their own expense, however, there is no state action. The state licenses and regulates private hospitals, but both the California and Umited States Supreme Courts have held that state regulation and licensing of a private actor, without more, will not make the private party's acts state action. ${ }^{224}$ The state's involvement in a minor's privately funded, par-

220. 19 Cal. 3d at 928,569 P.2d at 1290, 141 Cal. Rptr. at 302.

221. Calif. Welf. \& INST. CODE $\$ \S 5600-5803$ (West 1972 \& Supp. 1981). See supra note 116 and accompanying text.

222. Id. at $\S 5600.9$ (West Supp. 1981).

223. Norwood v. Harrison, 413 U.S. 455,465 (1973); J. NowAK, supra note 82, at $468-70$. The California Department of Mental Health has reached the same conclusion. Memorandum to Carl Rauser, Chief of Mental Health Program, from Dennis Eckhart, Office of Legal Affairs (Aug. 22, 1977) (on file with the California Law Review).

224. Jackson v. Metropolitan Edison Co., 419 U.S. 345, 350 (1974); Kruger v. Wells Fargo Bank, 11 Cal. 3d 352, 366, 521 P.2d 441, 449, 113 Cal. Rptr. 449, 457 (1974). Cf. Taylor v. St. Vincent's Hosp., 523 F.2d 75, 77 (9th Cir. 1975) (state regulation of private hospital not sufficient to make hospital's act state action).

The California Supreme Court's interpretation of state action under the Cabifornia Constitution is similar to that of the Umited States Supreme Court under the United States Constitution, but the Cahfornia court does not consider itself bound by federal decisions on this inatter, Garfinkle v. Superior Court, 21 Cal. 3d 268, 282, 578 P.2d 925, 934, 146 Cal. Rptr. 208, 217 (1978), and has recently appeared inore willing than the United States Supreme Court to find state action. Compare Gay Law Students Ass'n v. Pacific Tel. \& Tel. Co., 24 Cal. 3d 458, 595 P.2d 592, 156 Cal. Rptr. 14 (1979) (action by utility company constitutes state action for equal protection purposes) with Jackson v. Metropolitan Edison Co., 419 U.S. 345, 350 (1974) (action by utility company does not constitute state action for due process purposes).

Although under current California Supreme Court decisions a private commitment would not involve state action, the California court is moving in a direction that might eventually include such commitments within the scope of state action. Cf. Kruger v. Wells Fargo Bank, 11 Cal. 3d 352, 365, 521 P.2d 441, 449, 113 Cal. Rptr. 449, 457 (1974) (leaving open the possibility of a broader conception of state action in the future). While private institutions are not covered by the 
ent-initiated commitınent to a private hospital is thus insufficient to afford the minor the procedural protections of Roger $S .^{225}$

The awkward result is that the child whose parents can afford to pay for his institutionalization has less protection than his poorer counterpart. The court's einphasis on potential diagnostic errors and the severe consequences of erroneous commitments, however, have provided strong arguinents for those who advocate extending procedural protections to private commitments. Controversy over whether such protections should apply to private commitments remains a inajor impediment to legislative implementation of the court's decision. ${ }^{226}$

\section{The Admission Standard}

Having inodified the procedures of its proposed hearing in deference to parental involvement, the court modified the cominitment standard as well. Under section $6000(\mathrm{~b})$, minors in parental custody could be committed by their parents if the state hospital staff agreed that such a placement was appropriate. Now minors over thirteen could be hospitalized only if an independent decisionmaker deternnined that treatment in a state mental hospital was "reasonably likely to be beneficial" to them. ${ }^{227}$

Interpreting and applying the court's new standard, however, has not been an easy task. The standard could be read to require deterinining whether hospitalization would alleviate the mental illness that prompted the parents to try to commit their child. The court had noted that "the uncertamties in psychiatric diagnosis and the divergence of expert views . . . render the possibility of mistake significantly greater than in diagnosis of physical illness."228 Yet by rejecting LPS's focus on behavior in favor of a standard based on the likely benefits of treatment, the court potentially grounded the commitunent decision even inore firmly upon the psychiatric predictions it criticized. ${ }^{229}$

Since the court expected the decisionmaker to include an examination of the likely benefits of possible alternative treatinent inethods, ${ }^{230}$

due process clause, nothing prevents a legislature from adding procedural protections to its other regulations of mental institutions.

225. In Re John S., 135 Cal. Rptr. 893, 900-01 (2d Dist. 1977) (official report depublished by order of California Supreme Court); Cal. Att'y Gen. Op. No. 80-812 (1981); Letter from Bion M. Gregory, legislative counsel, by Stanley A. Lourimore, principal deputy, to Senator Alan Sieroty (Dec. 2, 1981) (on file with the California Law Review). Contra In re Application of an Alleged Mentally Disordered Person, MD 04472 (Los Angeles County Super. Ct. Nov. 6, 1981) (transcript on file with the California Law Review).

226. See infra text accoinpanying notes 472-76.

227. 19 Cal. 3d at 940,569 P.2d at 1298,141 Cal. Rptr. at 310.

228. Id. at 929, 569 P.2d at 1291, 141 Cal. Rptr. at 303.

229. It has been suggested that the evidence that Roger's hospitalization was not helping him was "uncritically transformed . . . mto a legal test." Hoffinan, supra note 219 , at 79 n.48.

230. The court indicated that the decisionmaker inight have to explore alternatives to com- 
further problems arose. How were the alternatives to be weighed? Did the court's emphasis on liberty mean that the child was entitled to the least restrictive placement? ${ }^{231}$ Could the decisionmaker consider the cost of the alternatives in deciding where to place the ininor, or was the likelihood of benefit the only criterion that could be applied? The court's opinion gave hittle guidance.

\section{The Court's Interim Solution}

The court expected the legislature to fill the gaps in its commitment scheine. ${ }^{232}$ "In the interim," the court continued in a footnote, "commitment under [LPS] is available to assure treatment and confinement of those minors whose condition is such that they are gravely disabled or dangerous to themselves or others." ${ }^{\text {233 }}$ A minor over thirteen who could not be committed under LPS could be committed by his parents if he executed a waiver indicating that he was aware of his rights and the consequences of the waiver, including the nature of the commitment, its probable duration, and the treatinent regimen. ${ }^{234}$ Meanwhile, parentally committed minors then in state hospitals could request release by petitioning for a writ of habeas corpus alleging that they were not mentally ill or disordered or that, even if they were mentally ill, they were not gravely disabled or dangerous and the treatinent for which they were confined was not reasonably likely to be beneficial. ${ }^{235}$

Even as a teinporary measure, the court's suggestions created problems for the inental health system. LPS commitments entail more procedural protections than the court thought parentally committed mimors need receive. Moreover, conservatorship is available only to those who are gravely disabled, while Roger $S$. was concerned with whether the adolescent was likely to benefit from the proposed treat-

mitment. 19 Cal. 3d at 931, 569 P.2d at 1292, 141 Cal. Rptr. at 304. Furthermore, it justified the requirement of counsel for the minor by noting that "a minor may be presuned to lack the ability . . . to discover and propose alternative treatment programs," implying that the minor's counsel bears that responsibilty. $I d$. at 938,569 P.2d at 1296,141 Cal. Rptr. at 308 .

231. It lias been argued that mental patients have a protected right to the form of treatment that least restricts their liberty. E.g., Zlotnick, First Do No Harm: Least Restrictive Alternative Analysis and the Right of Mental Patients to Refuse Treatment, 83 W. VA. L. REv. 375 (1981); see also Morse, A Preference for Liberty: The Case Against Involuntary Commilment of the Mentally Disordered, 70 CALIF. L. REv. 54 (1982).

232. 19 Cal. 3d at 940 n.11, 569 P.2d at 1297-98 n.11, 141 Cal. Rptr. at 309-10 n.11.

233. Id. In referring to minors who are either gravely disabled or dangerous to self or others, the court presumably intended to approve the use of the full range of LPS procedures, froin 72hour holds up to and including conservatorship. While dangerousness to self or others is grounds for short term commitunent, the only standard for long term treatinent under conservatorship is grave disability. See supra text accompanying notes 120-34.

234. Id. at $938-40 \mathrm{nn} \cdot 10-11,569 \mathrm{P} .2 \mathrm{~d}$ at 1296-98 nn.10-11, $141 \mathrm{Cal}$. Rptr. at 308-10 $\mathrm{m} .10-11$.

235. Id. at $940,569 \mathrm{P} .2 \mathrm{~d}$ at $1298,141 \mathrm{Cal}$. Rptr. at 310 . 
ment, not with the degree of his disability. If the legislature did not act soon, the court's solution would create the very procedural system that Roger $S$. rejected.

While conservatorship would not be needed if a mmor waived his right to a hearing, the court's brief discussion of the minor's ability to waive his rights left several questions unanswered. The court did not indicate how long a waiver would bind an adolescent patient. Moreover, the court inentioned a commentator's suggestion that a minor's waiver should not be accepted unless an attorney had consulted with the minor about the proposed commitment, explained his right to protest it, described possible alternatives, and ascertained that the ininor wished to enter the hospital without the hearing. ${ }^{236}$ It was unclear, however, whether the court endorsed this notion or simply wanted to bring it to the legislature's attention as a possible way to proceed.

If the court indeed intended that the ininor's waiver should be witnessed by an attorney, the lawyer's identity and orientation would becoine crucial. An attorney paid by the mimor's parents might face a conflict of interest in representing one side of an intrafanily dispute but being paid by another. A public defender might have to choose between representing indigent parents or witnessing their child's waiver. Whether the lawyer perceived hospitalization as confinement or as treatment could also affect the lawyer's assessinent of the mimor's awareness of the consequences of waiver.

Other probleins arose in the impleinentation of Roger $S$. for those adolescents then in state hospitals? For example, the court anticipated that the public defender of the county of the mimor's residence, and/or the state public defender, would identify and assist those mimors who might be entitled to release in the preparation and filing of petitions for habeas corpus. ${ }^{237}$ But how far was the public defender's advocacy to extend? If the court should find that hospital treatment was not likely to benefit the minor, would the attorney's job end there or inust the lawyer advocate some alternative placement?

These gaps in the court's opinion would have been umimportant if the legislature had adopted a commitinent scheme to fit the court's interpretation of due process, as the court anticipated. But despite several attempts, the legislature has not yet passed a Roger $S$. bill. Five years later, the court's interim solution is still in force. What this has meant, and how it happened, will be exammed in the rest of this Comment.

236. Id. at $938 \mathrm{n} .10,569 \mathrm{P} .2 \mathrm{~d}$ at $1296 \mathrm{n} .10,141$ Cal. Rptr. at $308 \mathrm{n} .10$ (referring to Ellis, supra note 67 , at 906 ).

237. Id. at $940 \mathrm{n} .12,569$ P.2d at $1298 \mathrm{n} .12,141$ Cal. Rptr. at $310 \mathrm{n} .12$. 


\section{IV}

\section{FALL-OUT FROM THE DeCISION}

\section{A. Impact at the State Hospital}

The state hospitals at Napa and Camarillo were the two institutions most immediately affected by the Roger $S$. decision, and they had to respond in several ways. First, every minor fourteen or older coinmitted to Napa under section 6000(b) had to receive notice of his right to a hearing. Second, admission procedures theinselves had to be restructured. Third, procedures had to be created to inforn every patient who turned fourteen while at the state hospital that judicial review of his commitment was available. The net result of these changes has been to reduce the number of adolescents in Napa and to make treatment programs subject to various legal and procedural intrusions. The sections that follow discuss in detail the impacts on Napa State Hospital. $^{238}$

\section{Immediate Fall-Out}

The first Roger $S$. impact on the state hospital systein was directed at adolescent patients in the hospitals at the time of the decision. Assuming that there must be youngsters besides Roger in the state hospital who did not belong there, the supreme court directed state and county public defenders to assist minors confined under section 6000(b) in petitioning for release if the minors so desired. ${ }^{239}$ This suggestion created considerable turnoil at Napa and strained the resources of the public defender's office. ${ }^{240}$

Roger himself had been discharged prior to the release of the supreme court's opmion. Other patients were discharged ahead of schedule "in order to gct them out of the Roger $S$. mess." 241 Meetings wcre held betwecn officials from Napa, the California Department of Health, and the state public defender's office to coordinate implemen-

238. This section will focus on the impact of Roger $S$. at Napa, both because of the availability of Napa personnel as resources for this project, and because of Napa's connection to the Roger $S$. litigation.

239. 19 Cal. 3d at 940 n.12, 569 P.2d at 1298 n.12, 141 Cal. Rptr. at 310 n.12.

240. The office did not expect this new task and had no funding to finance the effort. Halvonik interview, supra note 12. The experience of visiting the lospitals and interviewing the patients was also a personal strain on the attorneys who carried out the court's directive, forcing thein out of the adversary role as they came to realize that winning the case did not necessarily mean solving the problems of institutionalized youth. Hendon transcript, supra note 3 , at 5,9 . William L. Spicer, M.D., former director of the Napa children's program, commented: "The public defenders were shaken; they were for the most part young people who had never seen anything like this. They were emotionally sliaken. It was very hard for them. They needed a lot of support. They just didn't know what they were getting into." Spicer transcript, supra note 116, at 10.

241. Spicer transcript, supra note 116, at 8. Statistics on low many children left Napa this way were not available to the authors. 
tation of the decision in the least disruptive manner possible. ${ }^{242}$ The Napa staff had less than two weeks to identify those patients who were ehigible for review, to arrange meetings with public defenders, and to notify parents of the process. Despite the planning, however, at least one of the psychiatrists mvolved said the actual implementation "bordered on an atrocity."243

Many parents were shocked at what was happening. Dr. Williain L. Spicer, former director of the Napa children's program, said the families did not know what to do. "As you might expect, it threw the parents into a panic. These parents had been years getting their children to definitive treatment. . . . [A]nd they saw the possibility of a child being arbitrarily dropped back into their care without any resources except what had already been proven useless."244

At the hospital itself, Dr. Spicer said the interviewing process brought the entire therapy schedule to a standstill, because psychiatrists and social workers had to be available to meet with the public defender on each case. Rooms were set aside for confidential ineetings between patient and attorney. Treatment staff inembers were not allowed to attend. "Soine of the kids were terrified, some were interested, some were eager."245

Ezra Hendon, the deputy public defender who had coordinated the Roger $S$. hitigation, also took charge of the representation effort. Hendon personally interviewed more than eighty patients. Some had no idea of what was going on; soine made deliberate decisions not to go against their parents' wishes and seek release:

There were some very interesting and difficult ethical kinds of problems in deciding whether to represent a kid and if so, how to represent a kid; what to do for the kid and whether to pursue the due process adversary model to the hilt and if not, what else to do. There were very, very difficult questions. Many of these kids were very disturbed-clearly very disturbed and you couldn't open the doors and let them go. They had no place to go. They would hiterally starve to death if they were let out. And so what did you do? ${ }^{246}$

This was a difficult situation. These children had not requested the help of the public defender, and this put an extra burden on the

242. The Department of Health sent a letter to certain Napa staff members, holding them "personally responsible" for cooperation with the interviewing process and demanding that they avoid the possibility of a class action suit against the state as a result of this process. Dr. Spicer saved the copy that was sent to him and slowed it to the authors when interviewed at Napa.

243. Spicer transcript, supra note 116, at 9. "It was one of the most callous things that has happened around here, and a lot of callous things have happened around here because of the bureaucracy working for its own welfare and not the welfare of the families." Id.

244. Id.

245. Id. at 10.

246. Hendon transcript, supra note 3 , at 5. 
attorneys to determine what the patients really wanted. Hendon described his own approach:

For me, I sort of made a bottom line decision that the kid at least in my judgment had to be competent enough to say, "I don't want to be here, I want to get out." And if the kid couldn't talk to me, then it was just a waste of everybody's time. . . . My role was to be their lawyer to help them get out, if that's what they wanted. But I had to know that that's what they wanted before I could take some action on their behalf. ${ }^{247}$

Although Hendon did not keep statistics on the actual numbers, he recalled that "there couldn't have been more than a dozen" patients for whom he filed petitions for writs of habeas corpus. ${ }^{248} \mathrm{He}$ began a frustrating search for alternative facilities for patients who wanted out of Napa but who were clearly unable to survive outside of a treatment setting. ${ }^{249}$ He discovered the problem that many mental health profes-

247. Id. at 7,13 . If the child is competent, the lawyer has an ethical obligation to zealously represent the child's interests as perceived by the child, and to allow the child to make the important decisions. ABA CODE OF PROFESSIONAL ResponsibILITY EC 7-7 (1978); see id. EC 7-12. If, however, the child is not competent, the lawyer may generally make decisions on the child's behalf. Id. EC 7-11, 7-12. It is not clear exactly what constitutes "competence" in a child, but lawyers practicing in this area usually require as a minimum that the child be able to express a preference on the issue of his commitnent. See, e.g., Walker, Mentally Disordered Minors, in 3 California Juvenile Court Practice \& 25, at 337 (1981) (California Continuing Education of the Bar publication); Hendon transcript, supra note 3, at 13. A standard urged for use in juvenile court proceedings of a criminal nature is that the child's wishes will control if he can understand, with the help of his lawyer, at least the general nature of the proceeding, the reasons for it, and the possible consequences. IJA-ABA JoInt Commission on Juvenile Justice STaNDards RelaTING to CoUnSel For PRIVATE Parties § 3.1(b) commentary at 79-81 (1980).

After the Iawyer determines that the child is competent, another dilemma for the lawyer may arise. The child may want to oppose his commitment, and the lawyer will be obligated to pursue zealously the child's objective, even though the lawyer may know that the child's parents will not allow him to return hoine (if the parents even have legal custody) and there is no other place for him to go. Hendon transcript, supra note 3, at 5-6. In such a case, the lawyer inay try to arrange an alternative placement, only to find that none of the alternatives will accept the child. Id; Spicer transcript, supra note 116, at 10. Hence, the lawyer will be in the position of arguing against commitment to the mental institution, even though he knows that there is no other place for the child to go.

If the child is not competent, the lawyer faces the problem of determining what, if anything, to advocate on behalf of his client. One approach is for the lawyer to take no action unless the child is capable of stating a preference. See Mlyniec, The Child Advocate in Private Custody Disputes: A Role in Search of a Standard, 16 J. FAM. L. 1, 16-17 (1977-1978). This would certainly be appropriate where, as under Roger $S$, a child is not entitled to a lawyer until he has expressed a preference against commitment. Another possibility is for the lawyer to make an independent determination of what is in the child's best interests and advocate that position. It has been suggested that this would take the form of advocating the "least intrusive appropriate intervention." Walker, supra, $\$ 25.9$. Considering, however, the dearth of alternatives in many cases, this may amount to taking a stand against any placement of the child. See Thies, The Facts of Life: Child Advocacy and Children's Rights in Residential Treatment, in G. KoOCHER, supra note 79, at 86. Also, the uncertainty of mental health determinations creates additional problems for the lawyer who has the burden of deternining what is appropriate for the child or in the child's best interests.

248. Hendon transcript, supra note 3 , at 6 .

249. It appears that the question being explored in this search for alternatives was not whether a child would benefit froin treatment, but whether a less restrictive environment was 
sionals already had faced: there were few such alternatives available, and those that existed were not willing to take children with serious behavior problems. Few community-based alternatives offered locked ward care, and Hendon felt that state hospitahzation had stigmatized these children. ${ }^{2 s 0}$

Alternative placements were found for some children: those with less severe problems or those who had already made progress im treatment. Some parents took their children home; some were readmitted under LPS criteria. Others agreed to volunteer for contimued treatment and executed Roger $S$. waivers. ${ }^{251}$ Ultimately, only a few patients went to court, and none of them were released. ${ }^{252}$

\section{Ongoing Impact}

Although the Roger $S$. decision did not result in an immediate release of patients via habeas corpus proceedings, it did have the long run effect of reducing new admissions. Until 1977, the Napa adolescent program averaged about 150 patients; since the decision, the population has dwindled to an average of between 80 and $100 .^{253}$ Although part of this decline is due to other factors, ${ }^{254}$ some is attributed to the removal of section 6000 (b) as a commitment vehicle. ${ }^{255}$ Neither of the two interim alternative methods suggested by the court-voluntary admission via waiver and involuntary adımssion under LPS conservator-

available. Lack of alternatives remains a chronic problem. See Spicer transcript, supra note 116, at $15-16$.

250. Hendon transcript, supra note 3 , at 6 .

251. Id. at 7.

252. Transcript of interview with John Moy, deputy attorney general, at 1 (San Francisco, Cal., Feb. 5, 1981) (on file with the California Law Review).

Hundreds of minors aged 14 and older were in state hospitals at the time of the Roger $S$. decision, and initially it appeared that as many as 140 had been admitted under section $6000(\mathrm{~b})$ and would be eligible for Roger $S$. hearings. Id. But while the Napa County Superior Court began to plan how to handle this extraordinary caseload (according to interview with Judge Thomas Kongsgaard, Napa County Superior Court (Napa, Cal., Feb. 19, 1981)), only 40 patients expressed an interest in having hearings, and the number was later reduced to 16. Moy transcript, supra, at 1 . Only a handful actually went to trial, $i d$, and those tended to involve youngsters who were the most severely disturbed and therefore the least placeable in alternative settings. Because all parties acknowledged that some forin of treatment was necessary for these patients, it was the issue of possible alternatives, not the question of likely benefit from treatment, that was the focus of these hearings. The difficulty in finding alternatives may account for the fact that none of these patients were released. Hendon transcript, supra note 3, at 6.

A similarly low release rate was found in a study of legal review of commitments of adolescents aged 13 to 17 in Pennsylvania. After a hospital-initiated outside judicial review, only one child out of 43 was released. Meisel \& Roth, supra note 104, at 382.

253. Hollander transcript, supra note 165, at 1-2.

254. There has been a general shift in emphasis to commumity-based treatment and the Michael $E$. decision, see supra text accompanying notes 150-54, has reduced the power of juvenile courts to commit court wards without full LPS procedures. Hollander transcript, supra note 165, at 2; Spicer transcript, supra note 116, at 4.

255. Hollander transcript, supra note 165 , at 2. 
ship proceedings-has produced as inany patients as did section 6000(b).

An LPS conservatorship proceeding involves a judicial determination that a patient is gravely disabled. ${ }^{256}$ Fred Hollander, director of the Napa adolescent prograin, believes that to be admitted under that standard, a patient must now be "sicker" than was true before Roger $S .257$ Most children must exhibit very extreme behavior in order to be considered a candidate for conservatorship:

What happens with kids who eventually get here is that they commit some kind of crime that's significant enough to get into [the California Youth Authority]. Then [CYA], because these kids are disturbed, refers them to us. So that there is also a population of kids that never commit that significant a crime and who just go through this wandernig process and who are very disruptive to others but who never quite make it. We get the kids who finally make it. ${ }^{258}$

Voluntary commitment does not seem to work in the intensive setting of the Napa adolescent program. ${ }^{259}$ The program by design puts heavy pressure on the patients. Most are already chronic placeinent failures. Most have gone through three to five previous voluntary placements-and as many as twenty-five. ${ }^{260}$ Once faced with the highly structured regime of life on a locked ward, those who retain the power to leave may be tempted to do so. ${ }^{261}$ These "revolving door" admissions not only waste staff time and public money but also can disrupt the treatment of other patients. ${ }^{262}$

256. See supra note 134 and accompanying text.

257. Hollander transcript, supra note 165 , at 4.

258. Id. at 3. Allen J. Full, Jr., assistant program director and referral coordinator for the adolescent program, screens all applicants for admission. He has noted numerous instances "where a kid is referred three or four times and still never [inakes it] liere." Out of concern over this situation, he has begun to record such instances for future reference. Full transcript, supra note 166 , at 4 .

259. For a description of the structure of the Napa and Camarillo programs, see supra text accompanying notes $161-70$.

260. Full transcript, supra note 166, at 4; Hollander transcript, supra note 165, at 3; letter from Allen J. Full, Jr., to Carol Dillon and Margaret Roisman (Dec. 9, 1981) (on file with the California Law Review) [heremafter cited as Full letter].

261. Adolescents who have executed waivers retain the right to petition for a writ of liabeas corpus, whicl entitles thein to a hearing in Napa County Superior Court. However, simce the Napa court then applies the Roger $S$. standard of benefit froin treatment and tends to accept psychiatric judgments, see infra text accompanying notes $279-88$, it is likely that inany of these adolescents will simply be transferred to imvoluntary status.

262. See Full transcript, supra note 166, at 2; Hollander transcript, supra note 165, at 3.

Henry Marsliall, Camarillo adolescent admissions coordinator, takes the view that a voluntary admission is preferable to conservatorship and that it beliooves the staff to make the program worth stayimg in. He said when the therapy gets "hot," patients may want out, and about lialf of those who do can persuade their parents to authorize their release. The other half will seek a habeas corpus writ. About two-thirds of those who go to court in Ventura County are released. According to Marshall, the Ventura court uses a three-part standard in evaluating writs: (1) the willingness of parents to take the child home, (2) the availability of less restrictive alternative 
For these reasons, admissions coordinator Allen J. Full, Jr. has developed two separate admissions standards for the adolescent prograin-one for the voluntary patient and another for the involuntary patient. "[A]n involuntary placeinent can be successful in this program if they have the capacity to change," Full says. ${ }^{263}$ Desire to change rarely enters into this assessment, but roughly normal intellectual ability is a necessary factor. The would-be voluntary patient must display this same capacity to change and also must have enough insight to accept the long term goal of staying out of the mental health system or prison. ${ }^{264}$ Full rejects the developinentally disabled, severely organically damaged, or highly sociopathic patient.

No one is considered for voluntary admission without a personal interview with Full.

I ask them, "Where do you see yourself going ten years from now if nothing changes?" And most often the answer I get is, "Well, I'm going to be locked up." If a kid knows that, then that's probably a kid that has a fairly decent shot of making it in this program. ${ }^{265}$

Full tells them about medication, about the use of seclusion and restramt as behavior-modification techniques, and warns them that if necessary, they can be prevented from leaving at least temporarily by way of the 72-hour hold and the 14-day certification procedures of LPS. He looks for applicants with "an ability to stick through the hard times," but will take an involuntary patient over a voluntary one if other mdicators of success in the program are equal. ${ }^{266}$

Roger $S$. has apparently had a far greater impact on the admissions practices of the adolescent program than it has had on the neighboring children's program. ${ }^{267}$ Because of the nature of the psychoses

treatment, and (3) the benefit from treatment. Telephone interview with Henry Marshall (Dec. $21,1981)$. For a comparison of how the writ process works in the Napa County Superior Court, see infra text accompanying notes 279-88.

The major problem arising out of the emphasis on voluntary admissions at Camarillo appears to be finding witnesses to the minor's waiver of Roger $S$. rights. Camarillo draws heavily from Los Angeles County for its patient population, and the Los Angeles County public defender's office has refused to witness many of these waivers. Parents must pay for private attorneys to witness the waivers, or else children must be accepted on 72-hour holds under $\$ 5150$ of LPS, see supra text accompanying notes $120-22$, and then a Ventura County public defender meets with the child in the state hospital and witnesses the waiver. For more on the issues arising out of waivers, see infra text accompanying notes 384-95.

263. Full transcript, supra note 166 , at 1.

264. Id at 2. Full says it also helps if the child dislikes confinement. Some patients prefer confinement, "and of course, we have things within this program to make them unlike it." Id.

265. Id.

266. Id. Full contimues, "and sometimes I sit there and weigh it and say, we've got a 60/40, and based on a 60/40, let's give it a shot. On the other hand, if I have a kid that's maybe $60 / 40$ voluntary versus [an] involuntary, I'in going to take the imvoluntary every time." Id.

267. The decision did result in an immediate decline in the population of the children's program for the reasons discussed supra in text accompanying note 251 . According to both the past and present directors of the program, however, that trend has since reversed itself. Graham tran- 
that afflict the children's program patients, such patients generally meet the conservatorship requirement of grave disability. ${ }^{268}$ The adolescent program patients, on the other hand, may be psychiatrically described as psychotic, but function with apparent normalcy for significant periods of time, making conservatorship less certam. ${ }^{269}$ In addition, children's program patients are less likely to back out of the program because the program is designed to provide a more nurturing environment that meets with less patient resistance.

\section{Turning Fourteen at Napa}

The Roger $S$. decision makes its greatest intrusion into the practices of the state hospital when a patient reaches the age of fourteen, the age at which his parent's signature is no longer enough to keep him imstitutionalized. In the adolescent program, ${ }^{270}$ where most patients are older than fourteen, at most only three to five patients a year turn fourteen. At that poimt, a program staff member explaims to the patient his right to a hearing on the appropriateness of contmued treatment, as well as his right to volunteer for such treatment.

Whether or not the patient imdicates a desire to be released, a petition for writ of habeas corpus is prepared im the program office and filed in the Napa County Superior Court. A public defender is then appoimted to represent the child at the hearing. The child nnay tell the court that he wishes to waive his Roger $S$. rights, which terminates the proceedimgs. Should the child wish to be released, the court will determine, under the Roger $S$. standard, whether the child is still nentally disordered and likely to benefit froin treatment or whether a less restrictive alternative is available. In the past three and a half years, only one child has been released in this manner froin the adolescent program. If the court determines that continued hospitalization is appropriate, the child may be detained until he is inedically discharged froin the program, removed by his parents, or until his eighteenth birthday, whichever occurs first. The child retains the right to re-petition.

Until recently, when it adopted procedures similar to those just

script, supra note 109, at 3; Spicer transcript, supra note 116, at 8 . Donald Burns, former director of the Caunarillo ehildren's program, said in a telephone interview (Nov. 5, 1981) that Roger $S$. had hittle effect ou that program. See discussion of program structure supra in text accompanying notes 161-64.

268. Hollander transcript, supra note 165 , at 2.

269. Id.

270. Information regarding the impact of Roger $S$. on 14-year-olds in the adolesceut prograin was provided by Allen J. Full, Jr., assistant program director and referral coordinator, by letter, supra note 260 , and by telephone interview (Jan. 8, 1982). Information was also taken from Napa State Hospital, Types of Commitment Legal Criteria-Adolescent Program Admissions (Apr. 1981) (on file with the California Law Review) [hereinafter cited as Napa Adolescent Program Admissions]. 
outlined, the Napa children's program used a different system for informing fourteen-year-olds of their Roger $S$. rights. That system involved the use of a patients' rights advocate to explain the hearing process and to witness the waiver of rights. The patients' rights advocate is a state-employed worker who reports to the director of the state hospital but who is supervised through the Department of Developmental Services in Sacramento. ${ }^{271}$ However, the advocate is not an attorney, and according to the State Department of Mental Health, only an attorney can witness a Roger $S$. waiver. ${ }^{272}$ In an interview conducted while he was still responsible for the Roger $S$. waivers, Napa patients' rights advocate William A. Muirhead acknowledged the controversy over who should witness, but said he doubted that an attorney was more capable than he was of judging a patient's competence. ${ }^{273}$

Muirhead found that most children were capable of understanding their rights if explained in basic terms: "Do you want to hive here? Do you want to hive somewhere else? . . . You're old enough now to say, 'I want to live here,' or 'I don't want to hive here." "274 He estimated that about half the patients he talked to waived their right to a hear$\mathrm{mg},{ }^{275}$ sometimes as a result of pressure froin parents who did not want their child returned home. ${ }^{276}$

271. Transcript of interview with William A. Muirhead, Napa patients' rights advocate, at 1 (Napa, Cal., Feb. 19, 1981) (on file with the California Law Review'). The patients' rights advocate is also responsible for investigating complaints of mistreatment or infringement of rights made by patients, their families, and concerned staff members. Common complaimts concern inedication or demands for release froin the hospital. The advocate investigates the complaint and prepares a report for the hospital director, who inay also request a report from the program director. Another state employee, the special investigator, handles charges of abuse and investigates paticnt deaths. $I d$.

272. Memoranduin to local mental health personnel from Dale H. Farabee, M.D., Director of the Department of Mental Health, In re Roger S. Guidelines 2 (Aug. 20, 1980). Byron Chell, chief counsel to the California Department of Mental Health, told conferees at a department training program, "Legal Issues in Mental Health Services to Children" (Berkeley, Cal., Nov. 19, 1981): "We've taken the position it's [attorneys as witnesses] a good idea." Robert Walker, amicus curiae in Roger $S$., said at the same conference that while the Roger $S$. opinion did not mandate an attorney, it did suggest in footnote 10 that an attorney would be desirable. See 19 Cal. $3 d$ at 938 n.10, 569 P.2d at 1296 n.10, 141 Cal. Rptr. at 308 n.10. Walker felt that a tramed advocate would be approved by the court, but not an untrained person unfamiliar with the decision.

273. Muirhead transcript, supra note 271 , at 4.

274. Id. at 3,8 .

275. Id. at 4. Muirhead estimated that he talked to about one child each month concerning Roger $S$. rights. Id. at 3.

276. Id. at 8. Muirhead said that parents must occasionally be reminded that even they cannot deny their children due process. Id. This can be difficult:

We just did one, on a girl in the children's program. . . . She said she wanted to leave, she didn't want to live here, we were too strict on her. She had a talk with hor parents, and her parents asked her what she was going to do. She said, "l'll just hang around and watch TV and smoke and do a little drinking." And her parents were just as angry as hell at ine, because I represent the person who went over and talked to lier and explained her rights to her.

Id. at 2-3. 
Some at Napa criticize this process as interfering with treatment: Most kids just want to test and see if you let them do it. They don't really want to leave; they have no place to go. They may say they want to leave [if they are offered release by a public defender] who's coming over the hill like a white knight who's going to get them out of the institution and into a placement that's warm, loving, caring. Sure they want that. The fact is it doesn't happen. ${ }^{277}$

Dr. Richard Graham, director of the Napa children's program, said that quarterly evaluations are prepared for each child that mclude plans for community placement and an estimated timetable for release. The introduction of Roger $S$. rights can confuse children who have already discussed these plans for release with their psychiatrists. A new alternative-immediate freedom-can have a negative impact on the child's willingness to cooperate with treatment. Dr. Graham did acknowledge that the hearing process can have a positive effect on those children who believe that they can persuade the judge to let them go and who are then confronted with the reahty that the judge agrees with the psychiatrist's assessment. "But some kids can be very defeated by this, thrown for a loop."278

\section{Going to Court}

The implicit assumptions made in the Roger $S$. decision-that voluntary patients can walk out of locked wards at will and that some fourteen-year-olds who decide not to stay can win release-are challenged by the reahity of a visit to the Napa County Superior Court. ${ }^{279}$ Adult conservatees at the state hospital contestimg their status, LPS patients being certified for extended stays, ${ }^{280}$ and adolescents demanding Roger $S$. hearings ${ }^{281}$ all pass through these chambers. Almost all of them are denied release.

The Napa County Superior Court handles an average of fifteen habeas corpus hearings a week. The typical hearing lasts only about twenty minutes. A staff physician from Napa and an escort bring the patient to court. The public defender generally appears on the patient's behalf. The district attorney represents the hospital and calls the staff physician to the stand to testify on the patient's diagnosis, admissions history, and prognosis. The patient may also testify on his own behalf.

277. Spicer transcript, supra note 116 , at 9.

278. Graham transcript, supra note 109 , at 6.

279. The Napa court may handle more habeas corpus writs than any other court in the state. Kongsgaard interview, supra note 252.

280. Napa is an emergency center for several surrounding counties that do not have their own emergency psychiatric facilities.

281. In this category would be both adolescents who have turned 14 at the hospital and adolescents who arrived at Napa after signing Roger $S$. waivers and who now want to contest their commitment. 
Release is not a frequent occurrence. ${ }^{282}$

A typical example of the patients who ask for Roger $S$. hearings is Franklin, a sixteen-year-old who sought release from Napa in early 1981. Franklin had "borderline" mental illness that did not render him gravely disabled under LPS, but he had no home to go to. While Superior Court Judge Thomas Kongsgaard acknowledges that someone like Franklin might benefit from alternative treatment, no one could find an alternative for him, and Judge Kongsgaard could not say that treatment in the state hospital would not be of benefit. ${ }^{283}$ "If I turned that kid loose, what's he going to do? No one is prepared to provide a place for him. If I cut him loose, do you really think that's in his best interest? . . . I don't want it on iny conscience."284 In fact, Judge Kongsgaard says, "I frankly don't know if I've ever turned loose a Roger $S$. type."285

Judge Kongsgaard feels the courts are too involved in the process. "I apparently have more confidence and faith in the hospital than the legislature does," he says. ${ }^{286}$ His criticisms include the burden on the judge who is forced to play doctor, the interruption of treatment, the impact of the experience on the patient, the destruction of the physician-patient relationship resulting froin their opposing testimony at the hearing, and the consequences for future parent-child relationships. ${ }^{287}$ Judge Kongsgaard does acknowledge that the laws have made the hospital staff "inore cognizant of the fact that you can't warehouse people," and expressed the opinion that before LPS and Roger $S$., "at least some warehousing was going on . . . [but] I frankly feel now that we've had LPS ten years-and I've probably handled as many cases as any other judge-in iny opinion it hasn't resolved or improved anything."288

\section{Summary of the Napa Experience}

The Roger $S$. decision has had the following main impacts at Napa State Hospital: (l) it caused initial disruption of the treatment program, but did not result im the court-ordered release of any existimg adolescent patients; (2) it has had the longrun effect of reducing the number of new admissions, resulting in a patient population that is more seriously disturbed than was true in the past; (3) it has forced the

282. Kongsgaard interview, supra note 252.

283. Id.

284. Id.

285. Id.

286. Id.

287. Id. These criticisms are similar to those inade by others who advocate the parentalmedical model over the legal model. See supra text accompanying notes 107-09.

288. Kongsgaard interview, supra note 252. 
hospital to devise procedures for according minors Roger $S$. rights when they turn fourteen at the hospital, although these procedures have not generally resulted in the early release of patients from the hospital.

The main question raised by these results is whether the impact of Roger $S$. at Napa tends to confirm or rebut the supreme court's implicit assumption that children were being dumped in the state hospital who did not belong there. Not only is that question still unanswered, but as a result of the current use of LPS standards as the basic criteria for admission, it is impossible to know whether Roger $S$. standards would in fact prevent duinping.

The Napa experience does not seem to support a finding that there was significant dumping by parents of problem children into mental mstitutions. Although some acknowledge that dumping was an occasional problem in the past, the initial application of Roger $S$. to the 1977 patient population produced no successful challenges to commitment. Few, if any, of the children who reach age fourteen are released while at Napa when their commitments are subjected to judicial review.

There are several possible explanations for these results. It could be that institutionalization decisions have been appropriately made and that legal scrutimy only confirms those decisions. It could be that a lack of less restrictive alternatives is the mam reason children are not released and that courts defer to the inedical evaluation because, faced with an "all or nothing" choice, they reject an alternative that means no treatment. It may well be some coinbination of both.

The fact that there has been a longrun reduction in the number of minor patients referred to the state hospital may suggest that there was over-institutionalization in the past. It inay suggest that, at least informally, some children are now being diverted to the less restrictive alternatives that were a goal of Roger $S$. But the reduction appears inore probably to stem from the fact that most adolescents are being admitted to the state hospital under the stringent LPS standard of grave disability rather than the "likely to be beneficial" standard of Roger $S$. The Roger $S$. standard is generally not used to test the initial decision to hospitalize, but only to determine whether continued hospitalization is appropriate.

As long as that stricter standard is the predominant inethod of admission, there may be some minors deined admission who would qualify for admission under Roger $S$. The view of Napa personnel that the current population is more seriously ill than in pre-Roger $S$. years reinforces this possibility. Napa officials worry about what becomes of these children. Unfortunately, data to answer that concern does not 
exist. Additional information, however, is provided by the experience of the individual counties, which have selected from the options offered by the Roger $S$. court im devising new procedures to accomphish admission. The relative success of these various options is the subject of Part $\mathrm{V}$ of this Comment.

\section{B. Legislative Effort}

Prompt enactinent of new legislation governing the admission of minors to mental hospitals would have been the clearest and most effective way to provide a decisionmaking model to replace the parental autonomy inodel imvalidated by Roger $S$. The court's holding in Roger $S$. was not self-implementing, since it did not supply procedures for mental liealth professionals and parents to follow im order to hospitalize minors over fourteen. ${ }^{289}$

One year after Roger $S$. was decided, legislation was proposed that gave a three-member panel the power to decide whetler a minor would be hospitalized against his will. This decisionmaking model reflected little of the court's concern for parental autonoiny. Instead the proposed panel would have substituted both for the parents who had made the decisions to commit and for the medical personnel who had screened the admissions under section $6000(\mathrm{~b})$. The criteria the panel would have used in inaking its determinations reflected the assumption of the medical profession that mental illness in a minor should be dealt with differently from mental illness in adults. The legal rights accorded the minor in the proposed administrative liearings were not designed to treat the minor as an adult. Instead, the provisions appeared to have a two-fold purpose: most obviously, to comply with the legal definition of the minimum process due a minor in the custody of his parents, but more importantly, to screen hospital admissions so rigorously that the most appropriate medical treatment would be provided to minors.

Despite the effort to develop procedures that would accominodate the concerns of both the medical and the legal perspectives, the bill failed to enlist needed support from the mental liealth community. Even if the bill had deferred inore to the medical profession's antagomism to legal intrusion mto the doctor-patient relationship, however, it is unlikely that the bill would have succeeded because of the legislature's unwillingness to allocate funds to mstitute new procedural mechanisms for the commitinent of minors.

This first Roger $S$. bill presented a model for deciding when a ininor should be committed to a inental lospital against his will. Its development reflected the goals of Roger's lawyers im the Roger $S$. litigation. The procedures it proposed, while generally more concerned

289. See 19 Cal. 3 d at 940 n.11, 569 P.2d at 1297-98 n.11, 141 Cal. Rptr. at 309-10 n.11. 
with assuring appropriate treatment than was the Roger $S$. court, have been echoed by subsequent legislative attempts to implement the decision. The legislature's failure to enact the bill indicates the limits on any attempt to fashion a statutory model for mental health decisionmaking in California. This section explores the developinent of the first Roger $S$. bill, the procedures it proposed, and its failure in the legislature.

\section{The Proposed Legislation}

The lawyers who had advocated children's due process rights and who now sought implementation of their court victory found theinselves in alliance with state mental health officials, who foresaw disarray $m$ the provision of state-funded mental health services to minors if the legislature did not respond to the Roger $S$. decision. By late 1977 they had begun the process of draftimg legislation to implement the decision. Initially they contemplated an administration bill ${ }^{290}$ proposed by the Department of Health. When it became clear that the department would not be willing to sponsor the bill, the drafters sought the support of Assemblyman Frank Lanterman, who had fathered the origmal Lanterman-Petris-Short Act. ${ }^{291}$ Lanterman introduced the bill as A.B. 3648 on April 4, 1978, with Assemblywoman Leona Egeland, then chair of the Subcommittee on Mental Health, as cosponsor. ${ }^{292}$

After the bill had been introduced in the legislature, the drafters of the legislation held several working ineetimgs with representatives from the state Patients' Rights Office, ${ }^{293}$ the California Conference of Local Mental Health Directors, the Cahifornia Psychiatric Association, the State Public Defender's Office, and the American Civil Liberties Union in an effort to gain support for the bill. ${ }^{294}$ All participants in the ineet-

290. An administration bill's advantage is that it is more likely to be signed once it passes both houses of the legislature. Telephone interview with Ken Slavney, Patients' Rights Office, California State Department of Mental Health (Aug. 11, 1981).

291. Slavney interview, supra note 290. The Lanterman-Petris-Short Act is now codified at CAL. Welf. \& INST. Code $\$ \$ 5000-5400$ (West 1972 \& Supp. 1981).

292. Egeland's chief interest in the legislation was not the implementation of a court decision but rather the opportunity to incorporate into LPS a new standard for inental disability in children. To that end she added to the bill a definition of grave disability in children. A.B. 3648 $\$ 5008.2$ (as amended Aug. 11, 1978). See supra note 134 and accompanying text.

293. Patients' rights advocates are pubhicly funded to protect the legal, civil, consumer, and human rights of all recipients of psychiatric services in both public and private facilities. $C_{A L}$. ADMIN. CODE tit. ix, R. 863.2 (1976); telephone interview with Barbara Lurie, chief, Patients' Rights Office, Los Angeles County Department of Mental Healtl (Jan. 8, 1982).

294. Telephone interview with Margaret Fraser, then consultant to the Assembly Ways and Means Committee (assigned to work with Assemblyman Lanterman), now chents' rights officer, Cahifornia State Department of Developmental Services (Aug. 18, 1981); Slavney imterview, supra note 290; Walker transcript, supra note 3, at 3. Participants in the meetings ranged from "psychiatrists who didn't want anything to gung-ho lawyers that wanted everything." Hendon transcript, supra note 3 , at 9. 
ings were concerned that Roger $S$. might prevent children from getting needed treatment, and all wanted a bill, but the philosophical differences between those with a legal perspective and those with a medical perspective prevented the development of a firm consensus about what procedures would be appropriate. ${ }^{295}$ The participants' conflicting assumptions regarding the liberty imterest of children and the value of mental liealth treatment resulted im ongoing disputes about the extent to which the bill should extend the scope of the Roger $S$. decision.

The drafters of the bill chose an administrative rather than a judicial liearing because they thought an infornal administrative hearing would be less threatening to the minor than going into court. ${ }^{296}$ The administrative panel would have consisted of an attorney, a inental health professional, and a layperson from the community imterested in working with children. ${ }^{297}$ Section 6000 (b) had permitted the parent and the treatimg pliysician - those least likely to be concerned with the child's legal rights-to make tlie liospitalization decision. The proposed panel miglit in practice have made decisions that would have accommodated all three theoretical perspectives: legal, medical, and parental -at least to the extent the layperson would represent the community's concerns for family integrity and parental responsibility. Most supporters of the bill ultimately agreed to the adininistrative hearing, ${ }^{298}$ although debate continued over whether it would be more desirable and less costly to graft new procedures onto the old judicial system instead of settimg up a new administrative system. ${ }^{299}$

Although Roger $S$. dealt specifically with the state lospital, most participants in the meetimgs believed that its holding would also encompass adımissions to county liospitals. The drafters of the original version of the bill believed that inost abuses of patients' rights occurred in private facilities. Fron the drafters' legal perspective those abuses could be corrected by extending the scope of the decision ${ }^{300}$ to apply

295. Telephone interview with Quin Denvir, state public defender (June 18, 1981); Slavney interview, supra note 290.

296. Adnninistrative law judges were also considered to handle the proceedings but were rejected because of their already-overloaded calendars and their lack of expertise. Slavney interview, supra note 290. An administrative hearing was an innovation in the Cahifornia mental health system, Fraser interview, supra note 294, although it had been specifically endorsed by the court in Roger S. 19 Cal. 3d at 938-39, 569 P.2d at 1297, 141 Cal. Rptr. at 309.

297. A.B. $3648 \S 5147$ (as amended Aug. 11, 1978).

298. Fraser interview, supra note 294.

299. Denvir interview, supra note 295. Disputes also arose over what type of evidence would constitute an acceptable basis for the panel's decision and over who would sit on the admistrative panels and how they would be selected and financed. Slavney interview, supra note 290.

300. Making the procedures applicable to private facilities would probably have been ineffective in correcting these abuses in the absence of any additional enforcement provision. Slavney interview, supra note 290. 
the admission procedures to all inpatient psychiatric facilities. ${ }^{301}$ This approach obviously conflicted with that of the doctors, who resisted the imposition of legal procedures on the medical treatment model and who therefore advocated a conservative interpretation of Roger $S .^{302}$ Because of political resistance from the inedical community which the origmal version of the bill provoked, ${ }^{303}$ the bill was finally amended to make the procedures applicable only "where the cost of psychiatric inpatient services is paid in whole or part by public funds."304

Deference to the potential political strength of the general societal commitment to parental autonouny was reflected in the extension of hearing rights only to minors fourteen and over, despite the fact that the drafters of the bill agreed that the legislation should apply to all children. From the legal perspective, all children should be provided with due process safeguards, ${ }^{305}$ especially since younger children may actually be in greater jeopardy from inappropriate lospitalizations than adolescents. ${ }^{306}$ The bill's proponents feared, however, that extendimg rights to children under fourteen would be viewed as an undue intrusion into parental riglits and would provoke political resistance to the bill. ${ }^{307}$

The imtroduction to the bill also carefully acknowledged the importance of parental control by declaring tlie legislature's intent to "preserve the right and duty of parents to care for their child and to exercise their judgment on behalf of their child's lrealth and welfare."308 Although the stated legislative purpose included preservation of parental autonomy, the proposed procedures reflected the legal and medical perspectives of the lawyers and inental healtli professionals who drafted the bill. The procedures would have governed the admission not only of protesting mmors but also of those minors who would voluntarily consent to commitment. ${ }^{309}$

All applications by parents or guardians for commitment of a minor fourteen years or older were to be screened first by the local mental health program to determine whether the application met four inedical

301. A.B. $3648 \S 5130$ (as introduced Apr. 4, 1978).

302. Slavney interview, supra note 290.

303. Id.; Walker transcript, supra note 3, at 3.

304. A.B. $3648 \S 5130$ (as amended Aug. 11, 1978).

305. Walker transcript, supra note 3, at 3.

306. Telephone interview with Lurie, supra note 293 (June 18, 1981); Slavney interview, supra note 290.

307. Although some mental health professionals and legislators individually articulated this concern, it was never clear that any organized group represented this view. Slavney interview, supra note 290 . The only acknowledgement of the concern for younger children was the discretion granted to county persounel to provide explanations about the proposed treatment program and inpatient facility to minors under 14. A.B. 3648 \$5131(b) (as amended Aug. 11, 1978).

308. A.B. $3648 \& 1$ (as amended Aug. 11, 1978).

309. Id. $\S 5130$. 
and legal criteria: (1) that the minor in fact suffered from a mental disorder, (2) that the proposed treatment program could be reasonably expected to cure or ameliorate the inental disorder, (3) that the proposed treatment was the least restrictive alternative, and (4) that the treatment was in the minor's liome community or the benefit of treatinent outside the community outweighed the detriment of separation from the community. ${ }^{310}$

Once these determinations were niade, the county mental health worker was required to explain to the mimor: (1) the location and distance from home of the hospital, (2) the probable duration, benefits, and side effects of the proposed treatment, (3) the facility's physical surroundings, (4) the characteristics of other patients the minor might meet, and (5) the availability of educational programs. ${ }^{311}$ The minor also had the right to visit the facility prior to placement. ${ }^{312}$ After completing its evaluation, the local mental health program was required to arrange for the minor to see an attorney ${ }^{313}$ and to submit a report of its findings to the minor's attorney and to the administrative panel..$^{314}$

These provisions would appear to encourage the minor to assume a more active and responsible role in the decisionmaking process. Giving the child information about the proposed treatment program is essential to a knowledgeable exercise of due process rights from a legal perspective and might have therapeutically beneficial effects from a medical perspective, but it undermines parental control over a minor who might otlerwise passively accept the parents' decisions. These provisions, which in effect drew the minor into the role of decisionmaker to the exclusion of the parents, were intended to encourage minors to admit themselves voluntarily. ${ }^{315}$

To ensure that the minor's consent to hospitalization was truly voluntary, the minor's attorney was required to certify to the administrative panel that he had explamed the right to contest commitment and had determined that the minor wished to enter the facility and to waive the right to a hearmg. The minor's signature was also required to waive hearing rights. ${ }^{316}$ The administrative panel was required to review all subınitted documents and to initiate a hearing if it had any doubt regarding compliance with the procedures or the voluntarmess of the mimor's consent. ${ }^{317}$ These precautions reflect an assumption that a

310. Id \$ 5131(a).

311. Id. $\$ 5131$ (b). A minor under the age of 14 might also be given this explanation if the county personnel deemed it "appropriate in their clinical judgment." Id.

312. Id. § $5131(\mathrm{~d})$.

313. Id. $\$ 5132$.

314. Id. §5131(c).

315. Walker transcript, supra note 3 , at 3 .

316. A.B. $3648 \S 5133$ (as amended Aug. 11, 1978).

317. Id. A voluntarily-admitted minor could be released upon request, unless the parent and 
minor is not competent to exercise due process rights independently of adult supervision. The attorney and the administrative panel assume responsibility for reviewing the minor's decision-a parental role.

A minor who did not consent to admission could only be committed after an administrative hearing ${ }^{318}$ in which the panel made the requisite findings of mental disorder and of the necessity and propriety of treatment, thereby confirming the conclusions of the initial screening process. ${ }^{319}$ The provisions for the hearing procedure ${ }^{320}$ reflected the Roger $S$. holding that due process requirements for the cominitment of a minor in the custody of a parent are not as stringent as those for an adult or a ward of the court who is to be sent to a mental institution. ${ }^{321}$

The panel would have had discretion to grant the minor's request to obtam an evaluation by an imdependent psychiatrist or psychologist "where it is determined that the provision of such services would be useful for the resolution of contested issues." ${ }^{\text {"322 }}$ The bill also authorized the administrative panel to require the local mental health program to provide an alternative facility with a less restrictive and more appropriate treatment program. ${ }^{323}$ Periodic review of the treatment program was ensured by forbidding retention of a child im a facility for more than one year without an administrative hearing and for more than three years without the appointment of a conservator pursuant to LPS provisions. ${ }^{324}$ The bill required the facility to furnish a report of the treatment progress and justification for continued treatment to both the mimor's attorney and the administrative panel every ninety days until discharge of the patient. ${ }^{325}$

These provisions reflect inistrust of psychiatric diagnoses and skepticism of psychiatric imstitutions' willingness to relinquish their patients when appropriate. The bill attempted to cure these perceived de-

the professional staff agreed that the minor was both in need of treatment and gravely disabled or dangerous to self or others, in which case the minor might be detained under LPS provisions for adults. Id. $\S 5134$.

318. Id. $\$ 5135$.

319. Id. $\$ \$ 5131,5139$.

320. The public was to be excluded from the hearing, which was to be held in an informal setting most convenient to all parties. Id. $\$ 5136$. The minor had the right to notice and preseuce at the hearing, id. $\S 5138$, to present evidence and cross-examine witnesses, $i d$, to an interpreter, id. $\$ 5140$, and to a record of the proceedings, id. $\$ 5138$. Although all evidence of probative value was admissible, the panel's findings required support by a preponderance of evidence legally admissible in a civil judicial proceeding. Id. § 5137.

321. 19 Cal. 3d at 937-40, 569 P.2d at 1296, 141 Cal. Rptr. at 308-09; see supra text accompanying notes $191-99$.

322. A.B. $3648 \S 5138$ (as amended Aug. 11, 1978).

323. Id. $\$ 5139$.

324. Id. $\S 5142$.

325. Id. $\$ 5144$. A petition for rehearing regarding the need for treatment could be filed once every six months. $I d$. Admission for a 72-hour hold under the signature of a parent and a psychiatrist was to be permitted once every 60 days. $I d . \S 5145$. 
fects in the medical inodel by incorporating legal review into the diagnosis and treatment of the minor, by providing the minor with a psychiatric advocate in the adversarial process, by allowing the panel's collective judgment to be substituted for that of the mental health professionals in the selection of the treatment program, and by ongoing scrutiny of the treatment program by the administrative panel.

\section{The Failure of the Lanterman Bill}

A.B. 3648 was defeated in the Senate Finance Committee on August 17,1978 , a little over a year after the Roger $S$. decision. In a post mortem, Lanterman reported that while the adıninistrative hearing procedures and the scope of the bill's application to minors fourteen years of age and older appeared satisfactory to the Asseinbly and to the Senate Health and Welfare Committee, opposition surfaced in the Senate Finance Committee, where the State Department of Finance announced its opposition to the bill on fiscal grounds. Other opposition included county counsel staff from Marin and Alameda Counties, who indicated a preference for a court liearing rather than an administrative hearing and who objected to representation by counsel and to the diagnostic evaluation provisions. ${ }^{326}$

The cost of the proposed legislation combined witl the ambivalence of its backers provides the simplest explanation for the bill's failure. Proposition 13, mandating a limit in the rate of property taxes that could be levied by local governments, was passed in June 1978, while the Roger $S$. bill was making its way through the legislature. Fiscal analysts expected at the time that as a result of reduced property tax revenues, state funds might be required to bail out local governments unable to provide necessary services. ${ }^{327}$ Much more support than could be mustered would have been required to pass legislation entailing A.B. 3648 's expensive procedures ${ }^{328}$ in the atmosphere of fiscal tightfistedness prevailing in the California Legislature. ${ }^{329}$

The lack of support was manifested primarily by inost psychiatrists' refusal to support the bill. The medical profession had difficulty in coming to grips with the Roger $S$. decision, and it could not effec-

326. Unpublished memorandum from Assemblyman Frank Lanterman to interested persons re status of A.B. 3648 (Roger S. Bill) (Sept. 5, 1978) (on file with the California Law Review).

327. Special Section: Proposition Analysis, California Journal Ballor Analysis, 9 CAL. J. 1, 6 (1978) (special ballot analysis inserted after 9 CAL. J. 152).

328. The bill called for an immediate appropriation of $\$ 200,000$ to implement the act, and would have required a continumg allocation of $\$ 3,000,000$, Fraser interview, supra note 294, for attorney fees, A.B. $3648 \S 5132$ (as amended Aug. 11, 1978), administrative panels, id. §5147, support services and psychiatrists' fees, $i d$. $\S 5138$, mterpreters, id. $\S 5140$, and preplacement visits, id. § $5131(\mathrm{~d})$.

329. Walker transcript, supra note 3, at 3. 
tively advocate legislation upon which it could not agree. ${ }^{330}$ The mental health professionals' inclination was to urge that any available funds go to expanding direct psychiatric treatment of minors, not into procedural safeguards governing provision of that treatment. ${ }^{331}$

The California Psychiatric Association (CPA) and the California Conference of Local Mental Health Directors both opposed the original version of the bill, primarily because of its apphication to private as well as public facilities. ${ }^{332}$ Compromises regarding the scope of the bill, which were developed in the discussion meetings after the introduction of A.B. $3648,{ }^{333}$ were sufficient to persuade the CPA to take a neutral position on the bill. ${ }^{334}$ However, the provisions for an administrative panel and for explanations to the minor remained unappealing to the CPA, ${ }^{335}$ and psychiatrists brought in by the bill's proponents to speak on its behalf in legislative hearings could offer only lukewarm testimony. ${ }^{336}$ The discussion meetings ultimately proved inadequate to generate support for the bill. ${ }^{337}$

Similarly, many of the other groups whose support was necessary were ambivalent about parts of the bill. No participants could claim to represent authoritatively the groups whose interests they presented in the discussions. ${ }^{338}$ The basic philosophical differences between the medical and the legal perspectives were never resolved, so that the Roger $S$. bill finally represented an uneasy coinpromise with which no one felt entirely comfortable and which few could wholeheartedly support.

In addition to budget resistance and the legal-inedical conflict, the bill was frustrated by circumstances that tend to thwart any legislation related to mental health services for children in California. First, there is less advocacy on behalf of mentally disordered minors ${ }^{339}$ than there is on behalf of other populations in need of special services, such as

330. Denvir interview, supra note 295.

331. Walker transcript, supra note 3, at 3.

332. Kay Knepprath, government affairs consultant, California State Psychiatric Association, in remarks to a joint meeting of the California Psychiatric Association Children and Adolescent Coinmittee and Hospital Committee (Palo Alto, Cal., Nov. 13, 1981) [hereinafter cited as Knepprath address]. [Knepprath was also interviewed by teleplone on several occasions regarding proposed Roger $S$. legislation].

333. See supra text accompanying notes 293-95.

334. Knepprath address, supra note 332.

335. Knepprath interview, supra note 332 (Nov. 19, 1981).

336. Slavney interview, supra note 290; Walker transcript, supra note 3, at 3.

337. As one of the drafters of subsequent Roger $S$. legislatiou has observed, "You can hainmer out a bill on which everyone is neutral, and then how do you get support to get it through [the legislature]?" Knepprath address, supra note 332.

338. Denvir interview, supra note 295.

339. Denvir interview, supra note 295; Spicer transcript, supra note 116, at 5; Walker transcript, supra note 3 , at 7. 
persons with developmental disabilities. ${ }^{340}$ The parents of the developmentally disabled face a hfelong condition, and they tend to be organized and vocal about their children's needs. In contrast, the parents of mentally disordered minors are burdened by the stigma of psychological theories that attribute mental illness im children to parental influences. ${ }^{341}$ They may also hope that somehow their children's condition is transitory. As a consequence, these parents are unlikely to join together to advocate publicly for the needs of mentally ill children.

Furthermore, California's decentralized mental health program, created by the funding policies of the Short-Doyle Act $^{342}$ and the einphasis on cominunity-based treatment in LPS, makes implementation of statewide mental health pohicies difficult to achieve. County mental health professionals have substantial control over local mental health policies and programs, while state mental health officials have correspondingly diminished control ${ }^{343}$ and a relatively insignificant leadership role. Thus, although mental health professionals may be potentially the most effective advocates for their patients' needs, their efforts tend to be fragmented except to the extent that professional organizations such as the Cahfornia Psychiatric Association exert influence as the statewide voice for local concerns. Consequently, any attempt to imitiate mental health legislation from the state level will be frustrated unless a groundswell of concern from the counties provides needed support.

The people who sought to implenient the Roger $S$. decision in 1978 were lawyers and state mental health officials whose involvement with judicial processes made them conscious of the implications of failure to fulfill the court's expectation of legislative action. The legislative task proved difficult because of its financial and philosophical implications; it was impossible to pass a bill without the support of the county personnel and the professional medical organizations. ${ }^{344}$ At that time

340. Developmental disability is defined for purposes of providing state services as a disability that origimates before an individual attains age 18, constitutes a substantial handieap, and is expected to continue indefinitely. The term includes inental retardation, cerebral palsy, epilepsy, and autism, but not handicaps that are solely physical in nature. CAL. WELF. \& INST. CODE § 4512(a) (West Supp. 1981).

341. Graham transcript, supra note 109 , at 3.

342. See supra note 116.

343. Denvir interview, supra note 295. The Office of Children and Youth of the Department of Mental Health is a policy-recommending body only. As part of the Division of Planning and Development, its role is to recommend programs for inental health services to clildren and youth to the director of the Department of Mental Health, who, in consultation with the division chiefs, decides whether in turn to recommend the prograins to the counties. Any inplementation of the rccommended programs occurs through the consultation and monitoring functions of the regional service area offices of the Division of Community Services of the Department of Mental Health. Telephone interview with Hal Stein, Office of Children and Youth, California Department of Mental Health (Aug. 27, 1981).

344. The Department of Health was under severe criticism at the time because of inefficiency, 
these groups did not experience sufficient urgency in connection with the issue to advocate legislation to resolve it.

However, one effect of the passage of Proposition 13 in 1978 was the curtailment of local mental health programs that had provided alternatives to state hospitalization. ${ }^{345}$ The counties' dependence on the state hospitals increased at the same tinne that the legislative effort died. The county personnel would not realize fully the inplications for thein of the legislature's failure to implement Roger $S$. until the impact of the decision had been felt at the state lospitals and had filtered down to counties whiclı liad children witlı nowliere else to go.

\section{V \\ IMPACT ON THE COUNTIES}

The Roger $S$. decision has had a profound influence on county mental liealth procedures. The court removed a major means of involuntary commitment of minors - section 6000(b) - without providing a satisfactory replacement. This Part presents a survey of the three main tools used by county officials to adapt to the loss of section 6000(b): LPS conservatorship, voluntary waiver of Roger $S$. rights, and Roger $S$. hearings. It concludes that county practices are in disarray, are inconsistent with one another, and are in need of statewide legislation.

The authors of this Comment prepared and mailed a survey to mental health officials in each of California's fifty-eiglit counties to determine what procedures counties are using in thc wake of Roger $S .{ }^{346}$ Thirty responded. ${ }^{347}$ A majority of the counties responding have

infighting, scandals in the operation of the state mental hospitals, problems in the Medi-Cal program, and dissatisfaction with the general quality of public health care being delivered. This criticism culminated in a legislative reorganization of the Department of Health into five departments, Quinn, Health Reorganization: Five Departments, Same Disease, 9 CAL. J. 193, 194 (1978), mcluding one now called the Department of Mental Health. The lowered credibility of the Department of Health at this time could not have helped any bill that purported to increase the scope of the mental health system in California.

345. Gwen Foster transcript, supra note 2, at 12-13.

346. The survey questions are reproduced at Appendix A. A chart showing responses to the quantifiable questions appears as Appendix B. All written survey responses are on file with the California Law Review. Some responses were taken over the telephone or in personal interviews.

The survey was conducted in an attempt to clarify the contradictory information the authors of the Comment had received from state and county officials regarding the procedures the counties were using in the wake of Roger $S$. For example, the authors were informed that counties liad entirely abandoned the effort to provide due process rights to minors, that Roger $S$. hearimgs were cominon occurrences, that there is no legal way to hold a Roger $S$. hearing, that few children are conserved, and that all children are conserved.

The Office of Children and Youth of the California Department of Mental Health conducted a similar survey of the counties in late 1979. No counties reported using Roger $S$. proceedings at that time. Telephone interview with Betsy Burke, chief, Office of Children and Youth, California Department of Mental Health (Jan. 19, 1982).

347. Alameda, Butte, Calaveras, Colusa, Contra Costa, Del Norte, Fresno, Inyo, Kern, Lassen, Los Angeles, Madera, Marin, Mariposa, Merccd, Monterey, Riverside, Sacramento, San Di- 
adopted LPS conservatorship as the predominant inethod of institutionalizing ininors. ${ }^{348}$ More than half the counties that use conservatorship allow minors to waive their due process rights as well, entering the state hospital as voluntary patients, ${ }^{349}$ but the rest either specifically prohibit waivers or have no waiver procedure. ${ }^{350}$ Two counties prefer to institutionalize only minors who have waived their due process rights. ${ }^{351}$ Soune responding county officials did not know what procedures were used in their counties, ${ }^{352}$ and some counties utilize the state hospital so infrequently that they have no set procedural plan. ${ }^{353} \mathrm{Fi}-$ nally, three counties responded that they have already instituted formal Roger $S$. proceedings, ${ }^{354}$ and three inore counties are in the process of setting up such procedures. ${ }^{355}$

The sections that follow discuss the use of conservatorship, the use of voluntary waivers, and the creation of Roger $S$. proceedings. The discussion concludes with an overview of the county experience.

\section{A. Conservatorship as an Admissions Tool}

In a footnote, the supreine court in Roger $S$. suggested that coinmitment under LPS was an available interim procedure to be used until the legislature acted..$^{356}$ The conservatorship procedures-jury trial, right to counsel, proof of grave disability beyond a reasonable doubtundoubtedly meet and exceed the due process requireinents of Roger $S$. The conservatorship standard of grave disability is also stricter than the $R o g e r S$. requirement that treatment be shown to be beneficial. ${ }^{357}$

Although the actual operation of conservatorship proceedings varies from county to county, there are general similarities, especially in the mitial stages. An adolescent is seldom considered a candidate for conservatorship on his first contact with the mental health systein. ${ }^{358}$

ego, San Francisco, San Joaquin, San Mateo, Santa Clara, Santa Cruz, Shasta, Sonoma, Stanislaus, Sutter, Ventura, Yuba.

348. Alameda, Contra Costa, Fresno, Los Angeles, Madera, Marin, Merced, Riverside, Sacramento, San Diego, San Francisco, San Joaquin, San Mateo, Santa Clara, Santa Cruz, Shasta, Sonoma, Stanislaus.

349. Alameda, Contra Costa, Los Angeles, Madera, Marin, Merced, Riverside, San Diego, San Francisco, San Joaquim, Santa Clara, Stanislaus.

350. Fresno, Sacramento, Santa Cruz, Shasta, Sonoma. (San Mateo unknown.)

351. Monterey, Ventura.

352. Kern, Lassen.

353. Butte, Calaveras, Del Norte, Mariposa, Sutter, Yuba.

354. Colusa, Inyo, Marin. Only Colusa allows minors to waive their rights to a Roger $S$. hearing.

355. Los Angeles, San Diego, Santa Clara.

356. 19 Cal. $3 d$ at 940 n.12, 569 P.2d at 1298 n.12, 141 Cal. Rptr. at 310 n.12.

357. This is true even though the definition of grave disability was modificd after Roger $S$. was decided. See supra note 134 and accompanying text.

358. The description of the process that follows is drawn mainly from the Foster transcript, supra note 2, at 2-6, and the Sorrells transcript, supra note 159, at 3-4. 
Most have been in and out of less restrictive placements but are deteriorating rather than improving. A minor in crisis may be brought in on a 72-hour hold, then certified for 14-day intensive treatment, and be so clearly unable to go back to a less restrictive environment that county mental health workers begin to explore the possibility of long term residential care. Also, any child who is a ward of the court may be considered for state hospitalization in the course of exploring placement options.

Generally one person im each county is designated to screen applicants for admission to the state hospital. ${ }^{359}$ After consultation with treatment facility staff or the child's private physician, that person will decide whether to approach the state hospital about admission. At this point in counties that allow waivers, either a inental health worker or public defender will explam the child's due process rights to him and give him the option of volunteering for admission. The actual waiver of Roger $S$. rights is generally witnessed by either a public defender or private attorney. ${ }^{360}$ If the child refuses or is deemed incompetent to consent, a temporary conservator may be appointed ${ }^{361}$ and permanent conservatorship proceedimgs imstituted. ${ }^{362}$

The decision to seek admission to the state hospital involves consideration of many variables. Alameda County has developed a set of diagnostic, resource, and legal criteria to guide mental health workers in considermg the appropriateness of referral to the state hospital. ${ }^{363}$ Mmors in the following diagnostic categories are eligible for admission: psychosis requiring long tern treatment in a locked facility, severe behavior or personahty disorder with deterioration despite significant efforts at alternative treatment, organic brain syndroine, and adjustment reaction or neurosis that requires a specialized program available only at the state hospital. Resource criteria are based on the availability of

359. See Alameda County Children's Mental Health Services, State Hospital Referral Procedures for Minors (undated county guidelines) (on file with the California Law Review) [hereinafter cited as Alameda County Guidelines].

360. Of the 14 counties surveyed that allow waivers, only Merced and San Diego reported using nonattorneys to witness the waivers; seven counties-Colusa, Contra Costa, Madera, Riverside, San Francisco, Stanislaus, and Ventura-use public defenders as witnesses. The public defenders in Alameda, San Joaquin, and Santa Clara Counties liave not becoine involved in the process at all. The use of nonattorneys is controversial. See infra text accompanying notes 387-90.

361. CaL. WeLF. \& INST. CODE $\$ 5352.1$ (West Supp. 1981) allows the court to appoint a temporary conservator for a period not to exceed 30 days upon the "comprehensive report" of an investigating officer or the affidavit of the professional who is recommending conservatorship. If the proposed conservatee demands a court or jury trial on the question of whether permanent conservatorship is appropriate, the court may extend temporary conservatorship until the date of disposition of that issue, provided that in no event may the temporary conservatorship period exceed six months.

362. See supra text accompanying notes 129-39.

363. Alameda County Guidelines, supra note 359. 
alternative local facilities that could handle the patient's problems effectively.

Mental health workers must also consider the legal limits on hospital admission. Alameda County takes the position that an adolescent who signs a waiver may later sign himself out of the state hospital, and therefore the clinician must consider how likely it is that the patient will leave the hospital prematurely, thus making admission futile. If conservatorship is a better alternative, the worker is cautioned that "clear evidence" of grave disability must be documented to the court. $^{364}$

Parents often have a great impact on the strategy that a mental health worker will use:

Our experience with parents is that they are usually resistant to treatment, have on one or more occasions withdrawn the child from treatment or not followed through with it in the past. Soine attempt to sabotage the Napa treatment, others abandon the child during Napa hospitalization, a small number actually become involved and realize the problems and the needs. Etiologically, we tend to allege great parental contribution in making the child disturbed in the first place. Therefore, as we proceed with conservatorship it is usually from a position of not trustimg the parents. ${ }^{365}$

At least one county mental health official says no child can be found gravely disabled without a parent's consent to conservatorship:

If a parent comes to court and says, "I'll take my child hoine. I can get my child to eat and sleep in the house and keep their clothes on," then

364. That "clear evidence" may exist if the child falls in one of five "behavioral categories" that must be present for a child to be referred for conservatorship:

(1) Patient is unable to use the "elements of life necessary for health, safety and development, etc." at an age-appropriate level-e.g. shows severe self-care deficits to the extent that health is endangered: dresses in a bizarre inanner inappropriate to age group; does not maintain an adequate level of clothing to provide protection from the elements, engages in public nudity; has extreme eating or sleeping deviations (neglects nutrition to a life-endangering point-either through overeating or undereating, has food fetishes which endanger health, does not sleep enough to maintain health or sleeps too much), is unable to function in any school setting (hallucinations or delusions prevent the patient from attending school or profoundly impair his academic and social functioning).

(2) Patient repeatedly runs from home or other shelters and does not manage on the streets-e.g. is victimized or exploited by others, seriously cndangers himself, does not obtain appropriate food or shelter.

(3) Patient has a history of dangerous self-mutilation or of serious suicidal behavior, overt or disguised (mcreasing substance abuse, "accident-proneness" which frequently results in injury).

(4) Patient has a life-threatening medical condition and does not meet his medical needs-e.g. regularly refuses medication when provided, runs froin shelter where medical needs are met, behaves in a manner which will exacerbate the condition.

(5) Patient has a repetitive history of acting-out behavior dangerous to himself or others (e.g. assaultiveness, arson) which indicates that the ability to use internal or external limits for safety is impaired.

Alameda County Guidelines, supra note 359, at 5-6.

365. Survey response by Jane J. Wesley, case manager for children and adolescents, Stanislaus County. 
you have pretty well shot down your case: You can have a whole room full of psychiatrists willing to take the stand that on Ward C-1 the child refused food and ate the garbage, and took off his clothes and ran down the hall, and refused to sleep im a bed and slept in a closet. And then the parents say, "It must have been something he did in the hospital because at home he's not like that." Then you've lost your case. ${ }^{366}$

Once the child has been conserved, parents who are not competent to make major decisions for their children or who cannot be trusted to keep the child's best interests in mind can no longer imtervene to the child's detriment. ${ }^{367}$ For cooperative parents conservatorship can provide support for the decision to commit a child to a mental hospital. Putting the decision in the hands of the court reheves the parent of the burden of taking such a step. ${ }^{368}$ The parent may still play a role, however, if named by the court as conservator of the child. ${ }^{369}$

A conservatorship hearing requires a jury whenever the potential conservatee demands one. ${ }^{370}$ Many county workers and youth advocates believe that a jury is less likely than a judge to agree to conservatorship, out of reluctance to be responsible for committing a child, skepticism over the value of institutionalization, or because these adolescents are able to pull themselves together for the hearing. ${ }^{371}$ The use of psycliotropic drugs can stabilize a psycliotic patient in a very sliort time so that he might appear fairly nornal at a hearing, thus raising the reasonable doubt that conservatorship may not be appropriate. ${ }^{372}$

Judicial attitudes towards conservatorship vary as well. Napa County Superior Court Judge Thomas Kongsgaard sees conservatorship as a valuable means of avoiding the "revolving door" of sliort tern procedures, in which a patient inay repeatedly be admitted for 72-hour evaluations and 14-day certifications as his mental condition waxes and wanes. Through conservatorship, a patient can be momitored and treat-

366. Sorrells transcript, supra note 159 , at 6-7. While statistics on how often this happens are not readily available, the survey responses from those counties that reported on frequency of conservatorship denials are collected at Appendix B.

367. Full transcript, supra note 166 , at 6 .

368. Telephone imterview with Marlene Davis, children's coordinator, San Mateo County (Sept. 15, 1981). Sorrells believes that conservatorship is less destructive to the parent-child relationship than a Roger $S$. hearing would be: "As it is, it puts the mental health system im the adversary position. Because the parent doesn't have to be responsible for putting the child in, . . . the parent can be considerably more passive in the inatter." Sorrells transcript, supra note 159, at 9.

369. See infra text accompanying notes 376-77.

370. Cal. Welf. \& INST. Code $\S 5350$ (West Supp. 1981).

371. Telephone interview with Limda Arenchild, admissions coordimator, Shasta County (Oct. 1981); Hendon transcript, supra note 3, at 4. Youth advocate Robert Walker, supra note 3, adds that requests for jury trials are rare, because asking for a jury trial can mean a hearing delay of six months, during which time the patient can be held in the state hospital under temporary conservatorship. See supra note 361.

372. Sorrells transcript, supra note 159 , at 9. 
1nent can be provided when necessary without going through the LPS process over and over. ${ }^{373}$ In contrast, the San Joaquin County children's coordinator claims that if a child can "feed [himself], walk without assistance and answer time of day, despite our clinical findings that the child unay be blatantly psychotic," judges in that county will not conserve the minor. ${ }^{374}$

Alaineda County Superior Court Judge Michael Ballachey, who in 1980 handled the LPS hearings in his county, took a restrictive view of conservatorship:

A patient comes in to court who is obviously, from a layman's point of view, terribly, terribly ill. In the affidavit, the doctor is supposed to provide facts-for example: "The patient throws his food out the thirdstory window, he cowers in the closet and refuses to eat and has lost 50 pounds, he burns his clothes," etcetera. Instead, they'll write conclusions: "I think this person is gravely disabled because he cannot provide for his food, clothing and shelter." Bam! That's simply not evidence we can use to hold the patient. It makes me angry. And then I worry-worry sick-about the patient going out there in the wide, wide world and not being able to make it out there . . . ${ }^{375}$

Once an adolescent is conserved by the court, a final issue is whether the parent or an officer of the court will be named as conservator. "If at all possible," Sacramento County appoints the parent as conservator. ${ }^{376}$ Alaineda County allows the parent to serve that function if it is the only way the parent will cooperate. The trouble with putting parents $\mathrm{m}$ this position is that they are under constant pressure from the child to remove him froin the hospital. "It takes a parent whose feet are pretty well on the ground to resist that kind of inanipulation."377

The two fundamental criticisins of the conservatorship process are: (1) it may be antitherapeutic, and (2) its gravely disabled standard is too strict to serve as the inain vehicle for involuntary coinmitinents. Those who argue that a jury trial $\mathrm{m}$ open court is antitherapeutic stress the potential for trauna to the entire family when family probleins are dissected im public. Napa psychiatrist Dr. William L. Spicer flatly re-

373. Kongsgaard interview, supra note 252.

374. Survey response by San Joaquin children's services coordinator.

375. Oakland Tribune, Mar. 3, 1981, at C-5, col. 2-3.

376. Survey response by Mary Anne Wood, coordinator of children's mental health services, Sacrameuto County. Michael Jacobsen, conservator adıninistrator, Madera County, said in his survey response that parents and family members are given preference as conservators if found able and qualified to serve but that most parents cannot afford the legal counsel nccessary to act as conservators.

377. Sorrells transcript, supra note 159, at 7. In San Francisco, according to Children's Coordinator Mary Ann McKale, parents can and do become co-conservators, depending on the fanily situation. McKale's survey response, taken by telephone interview, is on file with California Law Review. 
jects the notion that a child can understand the consequences when he allows his attorney to "track out his dirty linen in court," because the minor cannot understand the implications for himself or his family when a history of incest, cruelty to animals, sexual misbehavior, or criminal conduct is revealed. ${ }^{378}$

The gravely disabled standard is also criticized as being too strict. The standard can screen out patients who could be admitted under the $R o g e r S$. requirement that treatment be beneficial but who do not qualify as gravely disabled. The consequence is that there are adolescents who cannot be treated involuntarily, who will not consent to voluntary treatment, and who camiot be treated adequately in any of the less restrictive alternative facilities that do not require Roger $S$. procedures. $^{379}$ It is almost impossible to quantify the frequency of this situation. We do not know, for example, how often county inental health officials do not seek conservatorships for adolescents because they know they cannot meet the gravely disabled test. ${ }^{380}$

For those adolescents who cannot meet the conservatorship standard, county officials may find specialized foster homes, board and care facilities, alternative residential treatment programs, or sometimes they "return the child home and wait for the situation to get worse." Often these children go from program to program or end up on the streets until they commit a crime and are diverted to the juvenile justice system or until their mental problems become so severe that they are conservable. ${ }^{382}$ In other cases, the county loses track of the child

378. Spicer transcript, supra note 116, at 3. Marin Connty Children's Coordinator Pat Jordan also considers the process traunatic. She recalled the case of a girl who was already hospitalized and was not so much upset over the appoimtment of the conservator as she was aware of the difference between winning and losing in a court of law. The girl became quite disturbed at being a "loser" in the process. Telephone interview with Jordan (Sept. 15, 1981). On the other hand, retired law professor and Bay Area psychiatrist Dr. Bernard Diamond says you cannot generalize about the impact of the hearing process on the patient; some patients do benefit from the full-scale "ceremonial" commitment. Transcript of interview with Dr. Diamond at 14 (Berkeley, Cal., Feb. 14, 1981) (on file with the California Law Review).

379. Sorrells transcript, supra note 159, at 7-9. See Lachs, Placing Minors in California Mental Hospitals, 4 WhitTIER L. REv. 57, 63-64 (1981).

380. Sorrells transcript, supra note 159 , at 9,12 .

381. Id. at 8.

382. Melvin L. Hayne, shief of youth and adolescent services, Sonoma County, said in a survey response, "Many adolescents are running to San Francisco and other places to become lost, prostitutcs and crimmals simply because we cannot treat them." San Joaquin's survey response indicates that most of the adolescents who are turned down for conservatorship come back into the system through the juvenile justice division. Mary Ann McKale, children's coordinator for San Francisco, said one patient was returned home and was subsequently shot to death breaking into a car. She said generally patients who are returned home "decompensate" and seek outpatient or inpatient care within one or two months, but rarely disappear from the systein. McKale survey response, supra note 377. 
completely. ${ }^{383}$

\section{B. Voluntary Waivers of Roger S. Rights}

The second major method of facilitating hospitahization of minors, either in conjunction with or as an alternative to conservatorship, is a voluntary waiver of rights by the minor. Counties that allow or require waivers received early guidance in adopting acceptable procedures from the state. The Department of Health outlined acceptable procedures as follows:

1. As part of the screening for admission to a state hospital, the Local Mental Health Director shall determine whether the minor wishes to make a voluntary admission.

2. This information shall be conveyed to the parents, and where the minor wishes to volunteer, arrangement shall be made with the parents to provide the minor with legal counsel. (The parents could secure the service of the local legal aid, a youth law advocacy group, public defender, or private attorney.)

3. The minor's counsel shall meet with the minor to determine for himself the minor's willingness to volunteer for state hospital services. Counsel, if satisfied as to the voluntary nature of cominitment, shall certify such to the Local Mental Health Program.

4. The Local Mental Health Program shall forward such certification along with other appropriate documents to the state hospital prior to the state hospital's acceptance of the minor's admission. ${ }^{384}$

The department also sent each county a sample "Waiver and Certification" developed by the legal office and still widely used to document minors' consent to hospitalization. ${ }^{385}$ As the waiver form indicates, a child who agrees to give up his Roger $S$. rights is effectively returning to the pre-Roger $S$. status quo. He relinquishes control to his parents, so that only they retain the right subsequently to sign him out of the hospital. He retams only the right to petition for release by writ of habeas corpus. ${ }^{386}$

383. Gwen Foster, director of children's services, Alameda County Health Care Services, reported:

One kid was an adolescent girl who spent, I think $\mathbf{3 0}$ days at the inpatient unit. Fifteen of those days we were trying to figure out how to get her into Napa under Roger $S$. She said she would sign herself in, but then, like most kids, she started thinking about that, and kept wavering, and she finally handled the whole thing by running away from the hospital. So we never saw her agam. And that's how that got handled.

Foster transcript, supra note 2, at 12.

384. Memorandum to local mental health personnel from Carl Rauser, Chief of Mental Health Program (Sept. 26, 1977) (on file with the California Law Review).

385. A copy of this forn is reproduced in Appendix C.

386. Napa Adolescent Program Admissions, supra note 270. It is interesting to coinpare waivers under Roger $S$. to waivers under Michael E., see supra text accompanying notes 150-54. Michael $E$. authorized the court to grant permission for court wards to enter a hospital volunta- 
These waivers raise several issues. Some counties only allow attorneys to witness waivers, while others allow mental health workers to do so. ${ }^{387}$ The State Department of Mental Health has advised, however, that only attorneys should witness waivers, and the Napa and Camarillo adolescent programs will not accept waivers by nonattorneys. ${ }^{388}$ Some counties have to rely exclusively on private attorneys to witness these waivers because public defenders refuse to become involved in the process, either because of understaffing, a conviction that the commitment plan should be tested in court, or fear of a conflict should they later be called upon to represent the child in a bid to be released from the hospital. ${ }^{389}$ There is some doubt that a waiver witnessed by an attorney im the parents' employ is valid. Napa officials have been advised to obtam written statements indicatimg who is paying for the attorney and, where a private attorney is involved, to arrange a meetmg between the child and the patients' rights advocate to ascertain whether the minor's rights were explained and whether the child in fact wishes to waive those rights. ${ }^{390}$ There are also those who argue that no child who is disturbed enough for the state hospital is

rily, without any parental involvement. The Roger $S$. waiver procedure requires that parents who retain custody still must consent to hospitalization.

387. See supra note 360.

388. Farabee inemoranduin, supra note 272, at 2; comments by Byron Chell, chief counsel to the California Department of Mental Health, and Allen J. Full, Jr., assistant program director, Napa State Hospital, at a department traming program, "Legal Issues in Mental Health Services to Children" (Berkeley, Cal., Nov. 19, 1981).

389. Burns interview, supra note 267; Foster transcript, supra note 2, at 10; Sorrells transcript, supra note 159, at 6; San Joaquin County survey response. Those counties responding that public defenders were not involved, for whatever reason, were Alameda, San Joaquin, and Santa Clara. Some counties have no public defenders and some did not specify.

In Los Angeles County, public defenders in three of five mental health regions have declined to become involved in the waiver process. Therefore, some Los Angeles patients destined for Camarillo are sent to the hospital without having waived their rights. Once there, a Ventura County public defender witnesses their waivers. This might be done, for example, if a child's parents could not afford a private attorney. Marshall interview, supra note 262.

Other Los Angeles patients-those being referred to Camarillo from two short term psychiatric facilities-are offered the opportunity to volunteer by counselors in mental health. See infra note 411 . Those waivers are approved by the presiding judge in Department 95 of the Los Angeles County Superior Court, who hears mental liealth cases in that county, but are viewed with skepticism by Camarillo officials because of the Department of Mental Health view that only attorneys can witness waivers. Marshall interview, supra note 262; see supra text acconipanying note 388.

390. The potential conflict of interest where the parents provide legal counsel for the minor was noted in a letter to the director of Napa from the Office of Legal Affairs (Mar. 13, 1978) (on file with the California Law Review). A private attorney retained by parents who sought to admit their daughter to Camarillo had certified that the minor had voluntarily waived her rights to a hearing under Roger $S$. Several months later the attorney represented the parents in court opposing the minor's request to leave the lospital. To prevent further such occurrences, Napa officials were advised to take precautions against potential conflicts of interest. 
competent to give a waiver. ${ }^{391}$

The use of waivers allows minors who would not qualify for admission under Roger $S$. to acquiesce to their parents' desire to hospitalize them. By allowing waivers as an alternative to $\operatorname{Roger} S$. hearings or conservatorship, a loophole in the screening function is created. Legal procedures were intended by Roger $S$. to screen the decision to institutionalize. When waivers are used, however, the only scrcening that occurs is the minor's competence to volunteer. There is clearly the potential for a competent minor to be pressured by parents and physicians to volunteer. The witness to the waiver may be able to screen for undue pressure, but cannot be expected to perforin the full Roger $S$. function of determining whether hospitalization would be likely to be beneficial.

Despite these questions, some counties rely heavily or even exclusively on waivers. ${ }^{392}$ The reason inost often cited is that a child who volunteers for treatment is more treatable. Santa Clara County, for example, has a policy of soliciting waivers from all children, whatever their age or legal status. ${ }^{393}$ Even those children who are sent to facilities that do not fall within the Roger $S$. requirements are given the opportunity to sign all waivers and authorizations that their parents sign, although their parents' signature alone is legally sufficient. Former Santa Clara County Children's Coordinator Brad Norman says that signing a waiver is an active way to take responsibility for one's own treatment, and taking such responsibility increases the likelihood that treatment will be successful. Norman also subscribes to the view that an ability to take responsibility and to comprehend the meaning of the waiver can coexist witl mental disorder that impairs otlier functioning. ${ }^{394}$

Ventura County relies heavily on waivers rather than conservatorship procedures. No adolescent suffering from a primary behavior disorder (as opposed to a major mental illness) is considered for conservatorship; only about two conservatorship hearings a year are held. The public defender witnesses approximately eight waivers a year. Children's Coordinator Randall Feltman reported lie is "satis-

391. Sorrells transcript, supra note 159 , at 6 . Sorrells did not subscribe to this view himself, but reported it as an attitude of others he had dealt with.

392. Ventura County's survey response indicates that waivers are used almost exclusively. Only im extreme cases of major mental illness might conservatorship be sought. San Joaquin County relies heavily on waivers because the local courts are reluctant to grant conservatorships for adolescents. See supra text accompanying note 374. Therefore, parents im San Joaqum gencrally hire private attorneys to witness the waivers. Monterey County reports exclusive use of waivers.

393. Telephone interview with Brad Norman, former children's coordinator, Santa Clara County (Sept. 15, 1981).

394. Id. 
fied" with admitting only voluntary patients rather than instituting Roger $S$. hearing procedures, which he said simply involve "more time and energy diverted from patient care issues. . . . Roger $S$. has the potential to take significant time at substantial cost for little value."395

Across the state, the use of waivers appears to depend on interagency cooperation and on whether the procedures used in a particular county make it relatively easy or difficult to obtain a waiver county inental health workers regard as vahid. The inajor problem regarding this method of commitment appears to be lack of county-by-county procedural consistency, which prevents a systematic approach to the issue of who should witness the child's waiver.

\section{Roger S. Proceedings}

Most counties have never established their own Roger $S$. hearing process, partly because two months after the case was decided, the Department of Health advised them that separate county action was inappropriate. The department's legal office concluded that the counties had no authority to devise their own procedures because the court had recommended legislative action and had specified that in the interim admission should be secured through LPS procedures or voluntary waivers. The department suggested that "the state hospitals should not accept any mimor between 14 and 17 years of age who objects to his or her placement, unless LPS procedures were used."396 The department felt that assurance of due process for commitment of minors required a uniform statewide solution. In part, it wished to avoid having due process procedures vary from county to county, simce all individuals would not receive the same treatment if each county acted imdependently. The legal office also wanted to avoid having to render decisions regarding the legal propriety of fifty-eight different county systems, without having the power to change those procedures that it found inadequate. ${ }^{397}$

Three years later, in response to counties' continued requests for help and expressions of frustration, and quite likely in growing realization that the legislature was not going to solve the Roger $S$. problem for them, the Department of Mental Health recanted its opinion that counties could not develop their own procedures to provide Roger $S$. hearings. The department offered new guidelines to help local mental liealth officials establish Roger $S$. hearings on their own. ${ }^{398}$

The guidelines described and discussed the Roger $S$. requirements

395. Survey response by Randall Feltman, children's coordinator, Ventura County.

396. Rauser Memoranduin, supra note 223.

397. Slavney interview, supra note 290.

398. Farabee inemoranduin, supra note 272 , at 2. 
as outlined by the court and interpreted by the legal office. The guidelines noted initially that the suprene court had suggested the juvenile court as an appropriate forum for the hearing, although a judicial hearing was not constitutionally compelled under the decision. Whatever the forum, the decisionmaker should be neutral and detached. ${ }^{399}$

The guidelines also explaimed the importance of providing counsel to discuss with the minor his rights and the consequences of waiving those rights. Counsel should certify that he has consulted with the minor (preferably, but not necessarily, without the parents present) about the commitment and the minor's right to protest and has ascertained that the minor wishes to enter the hospital without a hearing. The department suggested contacting county counsel, the pubhic defender, or legal aid offices if the minor does not have a private attorney. Apparently aware of the lack of cooperation from such sources in the past, this section of the guidelines concluded with the suggestion that the county bar association be asked to solicit lawyers to accept Roger $S$. chents on a paid or pro bono basis. ${ }^{400}$

Fimally, the guidelines discussed the importance of notice and hearing rights. The minor is entitled to adequate written notice of the basis for the recominended action. This requires an explanation of the basis for the proposed treatment, which would entitle the minor's attorney to treatment records upon consent of the mimor. The minor has the right to be present at the hearing, which must be held before commitment. The minor's attorney may have the minor testify at the hearing and may present evidence from independent psychiatric evaluations. Apparently despairing at the financial implications, the guidelines noted that "details regarding payment for such an evaluation and other hearing expenses will have to be resolved at the county level." 401 The minor must also be allowed to confront and cross-examme adverse witnesses, which requires that the minor's parents and the mental health professional recominending placement be available at the hearing for

399. Id. Attachment at 1. The guidelines also provided:

[I]n order to ensure neutrality, the decision-inaker should not be an acquaintance of the minor or the parents, should not have been retained by the parents to evaluate their child, should not be an employee of the proposed placement facility, and should not be a regular einployee of the county mental health program (except for purposes of conducting these hearings). If the decision-maker plays a dual role as therapist/evaluator in addition to the role of decision-maker, there is potential hability for violations of the minor's due process and civil rights.

We suggest that the decision-maker have a background in mental health, particularly juvenile matters. Furthermore, because of the nature of the hearing, we strongly urge that the decision-maker possess some legal background imcluding familiarity with basic due process requirements and an understanding of how to conduct a hearing.

Id.

400. Id. at 2.

401. Id. Attachment at 2 . 
cross-examination. A record of the proceedings must also be made that is adequate to permit meaningful judicial or appellate review.

Most counties, however, have still not initiated their own Roger $S$. hearing procedures. Several counties responding to the survey indicated that the responsible county legal officers were unwilling to act without legislative guidance and that money was not available at the local level. ${ }^{402}$ No counties have adopted the administrative, nonjudicial procedure suggested by the court, or the guidelines, but several have created judicial procedures that seein to work satisfactorily. ${ }^{403}$ Colusa and Inyo Counties both have developed siniple Roger $S$. hearing procedures. A superior court judge presides as an administrative hearing officer in a closed hearing with the parents present and the child represented by a pubhic defender. ${ }^{404}$ Calaveras County rarely institutionalizes minors, but indicated that, should the need ever arise, a $R$ oger $S$. hearing would be held. County counsel would represent the child, and a "community professional" would sit as hearing officer. ${ }^{405}$

Marin County has a dual system. Conservatorship is the inethod of choice, but if an adolescent does not appear to be a viable candidate for conservatorship, a Roger $S$. hearing is conducted instead. Only two Roger $S$. hearings have been held within the past two years. Under procedures approved by county counsel, those hearings were conducted in the superior court like the Inyo and Colusa hearings. Children's Coordinator Pat Jordan reported that from their limited experience, the procedure appears to be an "appropriate vehicle."406

402. When one mental health worker, who declined to be identified, told a Department of Mental Health conference that the county counsel in her county had refused to develop Roger $S$. procedures without legislative guidance, the department's chief legal counsel, Byron Chell, responded: "That's a cop-out. They're your lawyers, they ought to help you solve your problems." Department of Mental Health Training Program, "Legal Issues in Mental Health Services to Children" (Berkeley, Cal., Nov. 19, 1981).

Former Santa Clara County Children's Coordinator Brad Norman suspects that the reason his and other counties are not acting on their own but are still waiting for the legislature to act is that any county that acts alone "has to invent the wheel, and they do so with the knowledge that any subsequent legislation will undoubtedly require amendments to their plans." Norman interview, supra note 393.

403. While according to one survey those counties that have instituted Roger $S$. proceedings have uniformly adopted a judicial model, many county officials would prefer an administrative procedure in a local mental health facility with a mental health professional as the neutral factinder. The California Conference of Local Mental Health Directors conducted the survey, to which thirty-seven counties responded. Letter to Robert Egnew froin Albert E. Raitt, Jr., M.D. (Jan. 22, 1980) (on file with the California Law Review).

404. Responses to county surveys by Inyo and Colusa Counties. The need for this proceeding is rare in these small counties, however. Inyo has an average of only one patient in the state hospital at a time, and Colusa has admitted only two adolescents to Napa in the past ten years, has not had any occasion to handle waivers, and has not had any child turned down for admission under the Roger $S$. standard.

405. Survey response by Richard Boylan, mental health director, Calaveras County.

406. Jordan interviews, supra note 378 (Sept. 15, 1981 \& Jan. 13, 1982). 
Other counties are slowly coming to the decision that a Roger $S$. hearing will have to be of their own making. Santa Clara County mental health officials have decided they need a formalized Roger $S$. hearing procedure to commit children who do not meet the conservatorship standard. They are considering simply tacking Roger $S$. hearings onto the existing LPS calendar in superior court. Adolescents who would otherwise go through conservatorship hearings under the gravely disabled standard would go to the same court and face the same judge in a Roger $S$. hearing, which requires only a showing of mental disorder that would benefit from treatment and cannot be treated in a less restrictive facihty. ${ }^{407}$

The Los Angeles County Superior Court has developed an interim Roger $S$. procedure that may at some point be available to minors in that county who are admitted to Camarillo State Hospital. The Los Angeles County Department of Mental Health does not now utilize Roger $S$. hearings for such mimors, ${ }^{408}$ generally using either conservatorship or waivers by private counsel or public defender. ${ }^{409}$ So far, the Roger $S$. hearing procedure has only been applied to minors being admitted to a university psychiatric facility, but the procedure could be adapted to the due process requirements of the state hospital.

Judicial guidelines were issued in 1981 by Judge Stephen M. Lachs, then presiding judge of Department 95, which hears all mental health cases in Los Angeles County. ${ }^{410}$ Judge Lachs suggested the use of counselors in mental health ${ }^{411}$ in informal procedures designed to dimmish the number of cases brought to court and the accompanying attorney's fees and family trauma of an adversarial proceeding. ${ }^{412}$

Judge Lachs' interim rules provide that the counselor im mental health would step in after it has been determined that a minor could not or would not give a voluntary waiver. The counselor would interview the minor, his parents, and the physician, making a recommenda-

407. Norman interview, supra note 393; telephone interview with Panela Craig, who replaced Norman as children's coordinator at the end of 1981 (Jan. 13, 1982). Craig said she plans to inove forward as quickly as possible on the adoption of Roger $S$. procedures.

408. Telephone interview with Rose Jenkins, M.D., children's coordinator, Los Angeles County Departinent of Mental Health (Jan. 15, 1982).

409. Survey response by Rose Jenkins, M.D., children's coordinator, Los Angeles County.

410. Memoranduin To Whoin It May Concern froin the Honorable Stephen M. Lachs, entitled "Rules Inplementing the Roger S. Decision" (Sept. 4, 1981) (on file with the California Law Review), reprinted in Lachs, supra note 379, Appendix.

411. The counselor in mental health is a statutory position. CAL. WELF. \& INST. CODE § 6775 (West 1972). Counselors in mental health are employed by the court. In Los Angeles County, one of their duties is to interview and explain rights to inental patients on 14-day holds under LPS and to make recominendations regarding the disposition of their cases. Telephone interview with Ruth Olsen, counselor in mental health, Los Angeles County Superior Court (Jan. 4, 1982).

412. Telephone interview with Judge Stephen M. Lachs, Los Angeles County Superior Court (Jan. 4, 1982). 
tion to the court as to whether the minor should be hospitalized. If the court approved the recominendation to hospitalize the minor, the counselor would explain to all parties the minor's right to a hearing and to counsel. If any of the parties requested a hearing, or if the court disapproved the counselor's recommendation, a Roger $S$. hearing would be held, with the Departinent 95 judge sitting as decisionmaker.

A few Roger $S$. hearings for admission to the university facility have been held. ${ }^{413}$ The present presiding judge of Department 95 has indicated that he anticipates following Judge Lachs' guidelines in future cases, although the procedure may be modified to provide for a hearing in every case in which the counselor in mental health recoinmends hospitalization of a protesting minor. ${ }^{414}$ Application of the guidelines to admissions to the state hospital would require working out procedures to coordinate the activities of the court and the County Department of Mental Health. ${ }^{415}$

One stumbling block to impleinentation of this procedure for state hospital admissions is the question of whether the adolescent's waiver must be witnessed by an attorney. As currently applied, the procedure relies on whatever waiver inechanism is provided by the facility. Judge Lachs saw no requirement in Roger $S$. that waivers be witnessed by attorneys. ${ }^{416} \mathrm{He}$ chose the counselors im mental health as the main instruments of his procedure out of a concern for the costs of hiring attorneys for parent and child, especially since not all Los Angeles County public defenders will become involved in Roger $S$. cases. ${ }^{417}$ However, the State Department of Mental Health has advised that attorneys should witness all waivers. ${ }^{418}$ Therefore, if this procedure is to be applied to state hospital admissions, it is likely that soine modification must be made to assure that attorneys witness all waivers.

Even before Roger $S$., San Diego County maintained a policy of sending to the state hospital only children whose condition would qualify them for conservatorship under LPS criteria. ${ }^{419}$ That policy contin-

413. Telephone interview with Paul Donegan, counselor in mental health, Los Angeles County Superior Court (Feb. 1, 1982). In October 1981 Judge Lachs ruled that Roger $S$. apphed to private facilities, In re Apphication of an Allegedly Mentally Disordered Person, MD 04472 (Los Angeles County Super. Ct., Nov. 6, 1981) (transcript on file with the California Law Review), but the interim procedures had not been applied to privately-funded treatment at a private facility by the time Judge Lachs left Department 95 in late 1981. But see supro notes 224-25 and accompanying text.

414. Telephone interview with Judge Jeff Whitehill, Department 95, Los Angeles County Superior Court (Jan. 18, 1982); Donegan interview, supra note 413.

415. Jenkins interview, supra note 408.

416. Lachs interview, supra note 412.

417. Survey response by Rose Jenkins, M.D., children's coordimator, Los Angeles County.

418. See supra note 272 .

419. Telephone interview with Perry B. Bach, M.D., chief, Children and Adolescents Division, San Diego County Mental Health Services (Nov. 4, 1981). The information regarding San 
ues, and therefore, mental health personnel have not felt the need for Roger $S$. hearings for state hospital admission. Their concern has been to develop procedures that comply with Roger $S$. for admissions to the locked adolescent inpatient umit of the county hospital, where the average length of stay is one month..$^{420}$

In order to provide treatment in the county hospital to nonvoluntary minors who do not meet LPS criteria, the San Diego County Superior Court has agreed, like Judge Lachs in Los Angeles, to promulgate interim Roger $S$. rules. ${ }^{421}$ The procedures, which were developed by San Diego County mental health officials, patients' rights advocates, and county counsel, would utilize closed administrative hearings presided over by a counselor in mental health ${ }^{422}$ and would be under the jurisdiction of the mental health division of the superior court. A patients' rights advocate ${ }^{423}$ would meet with each child. If the child chose to waive Roger $S$. rights, the waiver would be signed by the child and authenticated by the advocate. ${ }^{424}$ The waiver and an affidavit by a physician certifying that the child would benefit from treatment would be forwarded to the counselor in inental health, who would authorize admission. If the minor protests, the counselor in mental health would act as hearing officer and the patients' rights advocate would act as counsel for the minor in a Roger $S$. proceeding. ${ }^{425}$

Those counties that have already implemented Roger $S$. procedures have done so on a much less ambitious scale than suggested in the court's opinion or by proposed legislation. Counties that have not developed procedures complain they have no money to do so. However, by simply adapting existing judicial structures, counties can create

Diego County was gained from several telephone interviews with Dr. Bach and from San Diego County Mental Health Services, Guidelines for Admission of Minors to Psychiatric Hospitals in California (Sept. 1, 1981) (on file with the California Law Review).

420. Bach interview, supra note 419.

421. Id. (Jan. 20, 1982). The procedures are set forth in County of San Diego, Adıninistrative Procedures for Voluntary Hospitalization of Minors: Pre-admission Hearing (Feb. 1982) (on filc with the California Law Review).

422. See supra note 411.

423. See supra note 293.

424. As in the Los Angeles court's plan, see supra text accompanying note 418 , this again raises the issue of whether the state hospital will accept a waiver witnessed by a nonattorney. The question may be noot, however, since it is not anticipated that the procedures will be applied to admissions to state hospitals.

425. Telephone interview with George Root, Esq. (Jan. 15, 1982). These procedures are similar to the provisions in the revised Sieroty bill, discussed infra in text accoinpanying notes 449-76. The similarity derives from their common origin. Root assisted in drafting San Diego County's procedures to comply with Doe v. Gallinot, 486 F. Supp. 983 (C.D. Cal. 1979), affd, 657 F.2d 1017 (9th Cir. 1981). See supra note 126 and accompanying text. Since the hospitals he represents opposed the original Sieroty bill, see infra text accompanying notes $458-67$, he offered the San Diego Gallinot procedures as a model for Sieroty to use in revising his bill. These procedures were also the basis for San Diego's proposed Roger $S$. proceedings. 
a vehicle for applying the Roger $S$. standard without exorbitant cost. In fact, the potential for some cost savings is present, since the Roger $S$. procedure does not include the right to a jury trial, which can add considerably to the expense of a conservatorship hearing. San Diego and Los Angeles are attempting a more elaborate procedure, and it remains to be seen whether coinplexity will increase the difficulty of actual implementation. It appears that the key to creating a successful Roger $S$. procedure is the cooperation of several groups of county officials: the county counsels who must pass on the legal sufficiency of the procedure, the public defenders who will very likely be called upon to represent children in these proceedings, and the judges who will sit as decisionmakers or delegate that responsibility to others. New procedures for admission to state hospitals also require the approval of the State Department of Mental Health. ${ }^{426}$ It is the difficulty of winning agreement from all concerned, and the uncertainty of carving out new ground $\mathrm{m}$ an area as treacherous as due process, that has led most counties to decide that other interim procedures will have to suffice..$^{427}$

\section{Summary of the County Experience}

The counties had three main options for facilitating hospitalization of minors after Roger $S$.: LPS procedures culminatimg in conservatorship, waivers by minors of their right to contest the decision to hospitalize, and independent creation of Roger $S$. proceedings. It is not surprising that most counties chose conservatorship as the primary vehicle for institutionalization: the procedural mechanism already existed, and county officials could rely on conservatorship hearings to provide full due process protection.

The use of conservatorship has forced mental health workers to consider not only diagnostic indications but also legal criteria in deciding what treatment plan to pursue. A child may need treatment in a locked facility, yet not be gravely disabled beyond a reasonable doubt. Judicial attitudes can be crucial im determining whether conservatorship is routinely approved or not. In some counties, conservatorship is rarely denied. In others, as many as one-fourth of the conservatorship petitions are rejected. This can force the child into the juvenile justice system, into alternative treatment settimgs that may not nieet his needs, or onto the streets until his condition deteriorates. Where that has been

426. The legal office of the Department of Mental Health has expressed concern that a proliferation of inconsistent county procedures may burden hospital staff with the task of reviewing more county documents and procedures to assure that children have been thoroughly and properly advised of their rights and that the local procedures meet Roger $S$. requirements. Telephone interview with Ellen Goldman, staff attorney, State Department of Mental Health (Jan. 14, 1982).

427. See Appendix A. 
a recurring problem, county officials who responded to the survey were sharply critical of the impact of Roger $S$. Still, many counties have learned to live with the system and have found that with judicial cooperation, conservatorship is only slightly more cumbersome than a Roger $S$. hearing would be.

Strict conformity to the legal restrictions of conservatorship can mean reduced flexibility for mental health workers trying to meet the needs of mdividual patients. If a minor is willing to consent to treatment, however, that obstacle can be avoided by execution of a waiver of rights. The problem is that many minors will not consent, some counties will not allow waivers, and the question of who should witness the waivers - an attorney appointed for the child, an attorney hired by the parents, an attorney employed by the facility, or a nonattorneyhas not been resolved.

Few counties have adopted Roger $S$. procedures. Lack of guidance from the state and reluctance to commit funds are the most often-cited reasons for failure to do so. Those counties that have adopted a simplified imterim Roger $S$. procedure with a superior court judge sitting as the decisionmaker report general satisfaction with the system. Most counties, however, feel compelled to wait for comprehensive legislation before acting.

It appears that the basic reason most counties manage to cope with the mental health system as shaped by Roger $S$. is that individually they' have relatively little need for the state hospital. Institutionalization' is clearly a last resort and, if other resources are available, may never be considered as a treatment option. ${ }^{428}$ Counties that rarely use the state hospital may never come across the patient who "slips through the cracks," one who is unsuitable for a less restrictive alternative and not conservable. Mental health workers who have faced that situation are sharply critical of this impact of Roger $S$. Counties that have the

428. While all counties regard the state hospital as a last resort, some have better in-county alternatives and some are aggressively "anti-state hospital," with significantly fewer admissions than others of comparable size. Full transcript, supra note 166, at 5 . Some are reluctant to use the state hospital for children, on the theory that the limited allocation of bed space at the hospital is better spent on adults who present a clearer threat to the local community. Id. The smaller, more rural counties, faced less frequently with adolescents in serious mental distress, may at any given time have no patients in the state hospital and no formal policy for accomplishing admissions. See Appendix B. These counties report relative success in diverting troubled youngsters into county mental health programs before a problem becomes too serious. A sense that they have little use for an elaborate procedure led one county mental liealth director to write off the Roger $S$. decision as simply "more bureaucracy." Survey respouse by Richard Boylan, mental health director, Calaveras County. Napa admissions personnel, however, reported that small counties may send patients to the state hospital who are less seriously disturbed than those from large counties, possibly because small communities are less tolerant of aberrant behavior than larger urban areas. Full transcript, supra note 166 , at 5 . This could also be the result of differences in community resources, forcing smaller counties to seek outside help sooner. 
option of either conservatorship or waiver may be better able to cope, especially if the judicial attitude towards conservatorship is lenient. But a county like Alameda, with a strict bench and madequate waiver procedures, has little choice but to search for alternatives when hospitalization is not possible.

A majority of counties responding to the survey reported that Roger $S$. has not changed the type of patients being referred, the timing of placement, the number of prior placements, or the number of patients committed to the state hospital. By contrast, Napa admissions personnel report that $\operatorname{Roger} S$. has resulted in a sicker patient population which has had more difficulty getting into the state hospital. ${ }^{429}$ The lack of frequent experience with Roger $S$. may account for the discrepancy im reporting on its impact between the counties and the state hospital personnel. It appears that it may take a statewide perspective to appreciate the full impact on the counties. Additionally, several county mental health workers who responded to the survey admitted that the impact of Roger $S$., if any, had occurred before they were imvolved in the process. Not only does this diminish the chance of comparing before and after results, it also may mean that some do not realize that other options are available. Still, a significant group of county workers see Roger $S$. as a problem and concur in the Napa reports.

It is certainly arguable that statewide uniformity of procedures is not necessary. Whether a county uses conservatorship, waivers, or Roger $S$. procedures is not as important as whether the procedures are working efficiently to secure treatment for those who need it. Clearly the county perspective is confused by the variety of practices being employed, and from that variety arises the danger that patients' rights are not being uniformly protected. The child's county of residence should not be the key to his admission to the state lospital. Only statewide legislation can offer the guidelines that will ensure uniform protection through uniforin practices. Some counties have despaired of ever seeing that legislation passed. Others continue to make do with interim procedures and press for relief. The likelihood of a legislative solution is the subject of Part VI.

\section{VI}

ReNewed Legislative AtTempts to

IMPLEMENT ROGER $S$.

Providers of mental health services, frustrated by the absence of legislatively sanctioned Roger $S$. procedures, began to push harder for

429. See supra text accompanying notes 253-57. 
implementation of Roger $S$. in late $1980 .{ }^{430}$ County officials, faced with a funding problem whenever an attorney was needed to admit a minor to a mental hospital, also urged legislation, hoping for statutory allocation of funds. ${ }^{431}$ Several procedural mechamisms were proposed to govern admission of minors to mental hospitals. The State Department of Mental Health proposed the incorporation of Roger $S$. procedures in a complete revision of LPS. Other groups limited their proposals to provisions for minors.

Despite the consensus that a new statutory scheme governing the admission of minors to mental hospitals would provide the most satisfactory solution to the problems created by the Roger $S$. decision, legislative enactment of a Roger $S$. bill was far from guaranteed. The same problems that defeated the first Roger $S$. bill-legislative unwillingness to finance new procedural mechamsms and conflicts about the scope of any proposed legislation-still frustrate attempts to implement the decision.

Nevertheless, the focus of the controversy has shifted in recent discussions about proposed admission procedures. The dichotony between the nedical and legal perspectives over the necessity for procedural safeguards in inental hospitalization still exists. However, it has taken the form of a debate over whether the scope of any proposed legal procedures should be confined to the state hospital facts presented in Roger S. - thereby preserving the traditional medical inodel intact for all other facilities - or whether procedures should be developed that would extend the legal benefits of procedural safeguards and the inedical benefits of ensuring the most appropriate treatment to a wider population of children.

This Part examines the variety of procedural inodels that have been proposed ${ }^{432}$ and assesses the likelihood that any Roger $S$. legislation will be successful. Finding that no statutory scheme governing the admission of minors is likely to be forthcoming in the foreseeable future, the discussion concludes that the legislature, by failing to act, has in effect adopted a decisionmaking model that treats the child as an adult, with the full legal rights of an adult. The legislative response thereby rejects both the concern for parental autonomy, articulated by the court in Roger $S$, and the concern for inedical treatinent appropri-

430. Bach interview, supra note 419 (Aug. 19, 1981). The California Psychiatric Association Area Council made implementation of Roger $S$. a top legislative priority for 1981 in September 1980. Knepprath address, supra note 332.

431. Stem interview, supra note 343.

432. This Part does not discuss proposals that do not address the specific requirements of Roger $S$. applicable to commitments in California, such as the American Psychiatric Association's GUDDELINES FoR PSYChiATRIC HOSPITALIZATION OF MiNORS (1981). 
ate to a child's age and condition, articulated by all those involved with providing mental health services to children.

\section{A. Proposed Legislation}

\section{The Mental Health Advocates' Proposal}

Two attorneys froin Mental Health Advocacy Services in Los Angeles $^{433}$ collaborated with a Los Angeles County public defender ${ }^{434}$ and the chief of the Patients' Rights Office in Los Angeles ${ }^{435}$ to draft a legislative proposal to put before the Conference of Delegates of the State Bar Association. ${ }^{436}$ The group represented a legal perspective, but its concerns were by no means limited to assuring due process rights. The advocates identified two major problems for minor patients: minors who do not require hospitalization are placed in private facilities by their parents, and minors in need of inpatient psychiatric services are denied admission to state hospitals as a result of both Michael E. ${ }^{437}$ and Roger $S$. because they do not neet LPS conservatorship criteria. 438

The proposal addressed these problems by requiring judicial review for the admission of any unemancipated minor to any licensed health facility providing treatment for mental disorders. ${ }^{439}$ A single procedure would apply to all minors, regardless of whether they were wards of the court or were im the custody of their parents. Because of its sweeping extension of Roger $S$. rights to all minors in all facilities, regardless of age, source of funding, or acquiescence by the minor, the proposal appears pohtically and fiscally impractical. Nevertheless, it offers one model of how legal and medical concerns might be integrated to protect the child's liberty interest and ensure appropriate psychiatric treatinent.

The procedures for admission would begm with an application to the superior court by the parent, guardian, or agency with custody of the minor. ${ }^{440}$ The court would appoint counsel for the minor and order

433. Jim Preis and Nancy Shea. Lurie interview, supra note 293.

434. David Meyer. Id.

435. Barbara Lurie. The Patients' Rights Office supervises the patients' rights advocates in Los Angeles County. See supra note 293.

436. Telephone interview with Jim Preis, Mental Health Advocacy Services, Los Angeles (Jan. 8, 1982). The draft was proposed as a resolution at the conference in September 1981. The conference took no action other than to create a committee to review the proposal and report back to the Conference of Delegates at its 1982 meeting. Id.

437. See supra text accolnpanying notes 151-54.

438. Mental Health Advocates Proposal, statement of reasons (on file with the California Law Review) [hereinafter cited as MHA Proposal].

439. Id. $\$ 6010$. Health facilities to which the provisions applied were those psychiatric hospitals licensed umder CAL. Health \& SAFETY CODE $\$ 1250$ (West Supp. 1981) to provide 24-hour care for inentally disordered patients. MHA Proposal, supra note 438, §6009(D).

440. MHA Proposal, supra note 438, $\$ 6010$ (a). The application would allege mental disorder, least restrictive placement, and substantial probability of significant improvement by involun- 
a hearing within three days. ${ }^{441}$ The minor would have the right to an evaluation by a mental health professional of his choice, with the cost of the evaluation to be borne, in the discretion of the court, by the person seeking to commit the minor. 442

The proposal would give the minor the right to be present at the hearing and to cross-examine witnesses. Hearings would be public unless otherwise requested by the minor. ${ }^{443}$ The minor could waive any of his rights and agree to hospitalization only after the court had interviewed the minor and determined that the minor was aware of the nature of the treatment plan and possible alternatives. ${ }^{44}$

The court could authorize placement of the minor upon finding sufficient evidence to support the application. However, authorization would automatically terminate after three months (or when the minor was discharged). Subsequent applications for additional periods of hospitalization would follow the same procedures as the initial application. ${ }^{445}$

The proposal would also require filing with the court within ten days after authorization of hospital admission an "Individual Treatment Plan" developed by a "multidisciplinary teain" mcluding the minor, the parents, the staff of the facility, representatives of the school district and any other agency involved with the minor, and any representative designated by the minor. It would specify goals, criteria for their accoinplishment, and a review of treatment progress. ${ }^{446}$ Grounds for a writ of habeas corpus (up to two petitions permitted within a three-month period) would be present if the minor or his representative believed that the program mandated by the plan was not in the minor's best imterest, that services were not being provided pursuant to the plan, or that the criteria for hospitalization were no longer met. ${ }^{447}$

Like the 1978 Lanterinan bill, ${ }^{448}$ the advocates' proposal envi-

tary hospitalization. Id. "Mental disorder" was carefully defined as "a serious and substantial psychological condition evidenced by behavior whieh indicates an inability to exercise rational, age-appropriate conduet and judgment and slaall include delusional, hallucinatory or incoherent thought processes." Developinental disability and substance abuse were specifically excluded. Id. $\S 6009$ (B). "Least restrictive placeinent" was also carefully defined as "that treatment modality which affords the most normal environment and the maximuin amount of personal freedom . . . consistent with the effective delivery of services . . . Id. $\$ 6009$ (E).

441. Id. $\S 6010(b)$, (c), (e). County counsel would present evidence at the hearing in support of the application; if county counsel found insufficient evidence to support the application, the applicant could present evidence. Id. § 6010(e).

442. Id. $\S 6010(\mathrm{f})$.

443. Id. \& 6010(g).

444. Id $\S 6010(\mathrm{~h})$.

445. Id. \& 6010(j).

446. Id. $\S 6011(\mathrm{~b})$.

447. Id. \& 6011 (c).

448. See supra text accompanying notes 290-325. 
sioned a legal process that would substitute for the treating physician's traditional role as screener and nonitor of hospital admissions. The proposal ignored any concern for parental autonoiny. At the saine time, it did not treat children as adults. Although the procedural safeguards-judicial review and public hearing-are similar to those accorded adults who are involuntarily hospitalized, the criteria for hospitalization and the required individual treatnient plan reflect less concern for the child's liberty interest than for the benefits a developmentally immature person may ganı from appropriate niedical treatment.

\section{The Sieroty Bill}

The Califorina Psychiatric Association (CPA) lias advocated a generally conservative approach to Roger $S$. legislation. ${ }^{449}$ Adhering to the barest requirements of Roger $S$. would most nearly preserve the traditional functions of parent as decisionmaker and physician as screener of the parent's decisions. Many psychiatrists liave seen the presence of state action in Roger $S$. as the premise for its requirenient of procedural safeguards. ${ }^{450}$ On that basis, the CPA has urged that Roger $S$. should be applied only to admissions to state or county hospitals or when treatment is to be paid at least in part by the state. ${ }^{451}$

This approacli also seened appropriate to CPA lobbyists in view of the conservative fiscal and philosophical posture of the current legislature. ${ }^{452}$ The bill that the CPA proposed therefore limited its scope to children over fourteen admitted to state or county inpatient facilities or private facilities contracting with local mental liealth prograins. ${ }^{453}$ The bill was based on a draft that had circulated in the State Department of Mental Health. ${ }^{454}$ This draft took the 1978 Lanternnan bill as a model for many of its specific provisions ${ }^{455}$ but utilized a judicial rather than

449. It should be noted that the organized psychiatric community is by no means unanimous in its view of the issue, having as it does its own share of civil libertarians who think that the scope of the decision should be extended to apply to all minors involuntarily committed to any mental health facility. Bach interview, supra note 419 (Aug. 19, 1981). Proponents of the 1978 Lanterman bill noted the lack of consensus among psychiatrists. Denvir interview, supra note 295; Slavney interview, supra note 290.

450. In this approach, Parham's guidelines for a neutral decisionmaker, see supra text accompanying notes 51-54, should control in the private sector, unless there is a finding that the parents are inadequate to care for their children, thereby invoking state action. Bach interview, supra note 419 (Aug. 19, 1981). For a discussion of the state action issue, see supra notes 217-26 and accompanying text.

451. Knepprath address, supra note 332.

452. Knepprath interview, supra note 332 (Apr. 20, 1981).

453. S.B. $1016 \$ 6000$ (b) (Mar. 27, 1981). Inclusion of both state- and Short-Doyle-funded facilities was made on the basis of the Department of Mental Health's interpretation of the scope of the Roger $S$. decision. Knepprath interview, supra note 332 (Apr. 20, 1981).

454. Knepprath interview, supra note 332 (Oct. 1, 1981).

455. Knepprath, Capitol Views, May 7, 1981, at 1 (Cal. Psychiatric Ass'n Newsletter). Coin- 
an administrative hearing. ${ }^{456}$

Senator Alan Sieroty introduced the CPA-sponsored bill as S.B. 1016 on March 27, 1981, with the understanding that it would be coordinated with a contemplated revision of LPS. 457 Controversy immediately arose over the scope of the proposed legislation. Proponents of the mental health advocates' proposa ${ }^{458}$ maintained that applying the procedures only where the state was a party to the admission discriminated against minors admitted to private psychiatric hospitals. Allegations of unequal protection raised the possibility that the legislation would invite further hitigation. Others pointed out that most abuses occurred in private facilities. 459 Moved by these arguments, Sieroty refused to proceed with the bill unless it applied to all facilities. ${ }^{460}$

The CPA agreed to an amendment of the bill on condition that it be written so that "mappropriate intrusion" into private hospitals and treatment programs would be avoided. The CPA also urged that the procedures be streamlined by providing an attorney only if the minor insists on a hearing and by making the hearings nonjudicial and as infornal and therapeutic as possible. ${ }^{461}$

The outcome of the revision was a provision that made the statute applicable to all children over fourteen (not wards of the courts nor emancipated minors) who are to be treated for a inental disorder at "any hospital licensed to provide inpatient psychiatric treatment." Legal forinalities and expenses were reduced in two significant ways: (1) a hearing officer ${ }^{463}$ was substituted for the juvenile court judge of

parable provisions to those in the 1978 Lanterman bill were made in the Sieroty bill for screening by the local mental health program, S.B. $1016 \$ \$ 6021,6022(a)$ (Mar. 27, 1981), explanations to the minor regarding the proposed treatinent program, $i d . \$ 6022(\mathrm{~b})$, appoimtment of an attorney for the minor, id. $\S 6023$, notice, $i d . \$ 6023$ (c), access to records, $i d$. $\S 6024$, waiver of the right to a hearing, id. $\S 6025$, basic procedural rights at the hearing, id. $\S 6026(1)-(5)$, an independent psychiatric evaluation, $i d . \$ 6026(6)$, admissibility of evidence, $i d . \$ 6027(\mathrm{~b})$, and informality of the hearing, id. $\$ 6027$ (a).

456. A provision was also added granting writ rights to a minor inpatient whose parents refused to consent to the minor's request for discharge, although the minor would be entitled to a hearing on a writ of habeas corpns anyway under CAL. WeLF. \& INST. CODE $\$ 7250$ (West Supp. 1981). S.B. $1016 \S 6028$ (Mar. 27, 1981).

457. Whichever bill was acted upon first would incorporate the relevant provisions of the other. Stein interview, supra note 343.

458. See supra text accompanying notes $433-47$.

459. Telephone interview with Sharon Gold, special assistant to California State Senator Alan Sieroty (Dec. 21, 1981).

460. Bach interview, supra note 419 (Aug. 19, 1981); Gold interview, supra note 459; Knepprath address, supra note 332. According to these sources, Sieroty was also concerned that exempting private facilities would be ethically questionable in view of his personal stockholdings in private psychiatric facilities.

461. Knepprath interview, supra note 332 (Oct. 1, 1981).

462. S.B. $1016 \& 6010$ (b), (c) (as amended July 1, 1981); Bach interview, supra note 419 (Aug. 19, 1981); Lurie interview, supra note 293; Stein interview, supra note 343.

463. The hearing officer might be a counselor in mental health (see supra note 411). S.B. 1016 
the original version, and (2) "minors' rights advisors"464 rather than attorneys were given the job of advising minors of their rights and assuring knowing waivers. The most controversial feature of the revised bill was that it provided two sets of procedures: admissions to state hospitals were to be screened by both the treating physician and local inental health officials ${ }^{465}$ as provided in the original Sieroty bill, while admissions to non-state hospitals were to be screened only by the treating physician. ${ }^{466}$ In addition, the procedures for meeting with a minors' rights advisor to determine whether the minor wished to waive a hearing were more informal for non-state than for state hospital applicants. ${ }^{467}$

S.B. $1016 \mathrm{im}$ its amended form provided for more than the Roger $S$. court required by proposing procedures to govern the private sector. Providing Roger $S$. procedures for admittees to all psychiatric impatient facilities in the state is obviously much more expensive than providing thein only to admittees to the two state hospitals. A bill that so extended the scope of the Roger $S$. holding becaine vulnerable to the lobbying efforts of those who opposed extending Roger $S$. to private facilities for philosophical rather than financial reasons. ${ }^{468}$

Legislative action on S.B. 1016 was suspended when the legislative analyst and the State Department of Fmance advised that the bill would have "undetermined but substantial cost."469 The California Hospital Association (CHA) ${ }^{470}$ announced its opposition to the bill be-

$\$ 6010$ (a) (as amended July 1,1981 ). The use of a hearing officer appointed by the court appears to be a compromise between the judicial hearing tradition in California's mental health system and the administrative hearings proposed in the 1978 Lanterman bill and recommended by the California Conference of Local Mental Health Directors. Stein interview, supra note 343. This compromise, suggested by the use of a hearing officer in the LPS revision proposed by the State Department of Mental Health, provides court backup for the procedure without the formalities of a judicial hearing. Bach interview, supra note 419 (Aug. 19, 1981).

464. "Minors' rights advisors" are defined as Patients' Rights Advocates, see supra note 293, counselors in mental health, see supra note 411 , or a person designated by the county. S.B. $\S 6010$ (d) (as amended July 1,1981 ).

465. S.B. $1016 \S \S 6021,6022$ (a), (b) (as amended July 1, 1981).

466. See id. $\S \S 6030-6035$. To cure the inequality in screening procedures, a proposed alternative provision would have required the local mental health director to designate someone not affiliated with the facility to screen admissions to facilities where treatment would be publicly funded and a panel without direct institutional connections to screen admissions to private facilities. The screening personnel would need to be knowledgeable about community resources in order to assure that the least restrictive alternative is being utilized. Stein interview, supra note 343.

467. Compare S.B. $1016 \S \S 6023-6024$ (as amended July 1, 1981) with id. $\S \S 6031-6033$.

468. For example, the opposition to S.B. 1016 by the California Hospital Association, while no doubt gronnded in private hospitals' aversion to procedures that undermine the medical nodel, gaimed its force from its allegations of prohibitive costs.

469. Id.

470. The CHA represents 600 acute-care facilities in the state, some of which have psychiatric wards. Freestanding psychiatric facilities are included in the Association. Telephone interview with Ron Youngren, director of organizational network relations for CHA (Jan. 5, 1982). 
cause of its costs and because the CHA believed that Roger $S$. should be incorporated in the Departinent of Mental Health's proposed revision of the entire LPS. The CHA also felt that the proponents did not adequately consult with the CHA before proposing legislation that would have directly affected CHA interests. ${ }^{471}$

Many doctors would like Parham's inedical model ${ }^{472}$ to govern commitment of minors in California to the fullest extent possible, and therefore they want to limit Roger $S$. cominensurately, or displace it completely. They felt encouraged in their position by the attorney general's opinion in late September 1981 that Roger $S$. does not apply to privately funded treatment at private facilities. ${ }^{43}$ They were further encouraged when the legislative counsel opined in December 1981 that legislation assuring due process proceedings to minors committed to a state mental facility but not to minors committed to a private mental facility would be constitutional. ${ }^{474}$ However, doctors who agree that applying Roger $S$. to admission procedures interferes with delivery of services from a nedical perspective do not necessarily agree on what legislative compromises are appropriate in view of the problems created by the absence of legislation. Doctors associated with private facilities, such as those represented by the CHA, have been more insulated from the treatment dileminas engendered by $\operatorname{Roger} S$. than have been doctors who care for patients dependent on state funds for treatment. The fornier are less inclined to compromise the medical model in commitment of minors and therefore take a hard line in favor of a conservative interpretation of the scope of Roger $S$.

In contrast, mental health professionals whose work with patients is funded at least in part by the government indicate greater acceptance of the value of (or resignation to the inevitability of) procedural safeguards and legal requirements in their work. Consequently, they appear willing to compromise the medical nodel in the interest of making treatment more available for their patients.

The compromises represented by the amended version of the Sieroty bill were not sufficient to save it. The CPA subsequently withdrew its support for the bill in response to the CPA Hospital Committee's opposition to the bill's application to private facilities. ${ }^{475}$ Without the

471. Id.

472. See supra text accompanying notes 51-54.

473. Op. Att'y Gen. No. 80-812 (1981). The opinion concludes that the private decision of a parent to place his or her minor child in a private mental facility without the involvement of any state agency does not constitute state action and that the minor therefore has no procedural due process right to a hearing on the need for treatment under either the state or the Federal Constitution.

474. Letter from Bion M. Gregory, legislative counsel, by Stanley A. Lourimore, principal deputy, to Senator Alan Sieroty (Dec. 2, 1981) (on file with the California Law Review).

475. Gold interview, supra note 459; Knepprath interview, supra note 332 (Nov. 19, 1981). 
support of the bill's sponsors, and given the financial objections of the legislature, Sieroty foresaw no possibility of success for the bill. S.B. 1016 was withdrawn in January 1982.476

\section{Reexamination of LPS}

The Department of Mental Health proposed that LPS be reexammed and revised in its entirety. The effort was headed by Byron Chell, the department's chief counsel, who conducted a statewide campaign to restructure the Act. ${ }^{477}$ Chell's goal was to change LPS to reflect modern mental health concepts as well as current legal doctrines of due process for mental patients by redefining the criteria for commitment and the basis for state action in imvoluntary commitments. ${ }^{478}$

Before proposing any statutory changes, Chell distributed a lengthy conceptual exammation of commitment procedures to mental health personnel and other interested persons throughout the state. ${ }^{479}$ In this essay Chell distimguished two bases for civil detention of the mentally ill: the pohce power, which the state employs to protect persons from harm by others, and the parens patriae power, which the state employs to protect and care for persons who are not capable of caring for themselves. ${ }^{480} \mathrm{He}$ viewed confusion about the rationale for exercise of the parens patriae power as the source of hitigation arising from current mental commitment procedures.

Chell identified three elements essential to the involuntary commitment of a person pursuant to the parens patriae power: (1) the person is mentally disordered, (2) the person is in a "dangerous situation" as a result of the mental disorder, and (3) the person lacks the capacity

One of the authors of this comment attended the joint meeting of the CPA Child and Adolescent and Hospital Committees on Nov. 13, 1981, at which the Hospital Committee expressed its opposition.

476. Gold interview, supra note 459 (Jan. 14, 1982).

477. See B. Chell, After a Decade of L-P-S-Uncertain Times in Mental Health Law: A Conceptual Reexamination of Cahfornia Law Relating to the Civil Commitunent of the Mentally Ill with Recommendations for Change 4, $114 \mathrm{nn.7-8}$ (Feb. 1981) (unpublished report of the Departunent of Mental Health) (on file with the California Law Review) [hereinafter cited as Chell, Reexamination]; transcript of interview with Byron Chell, chief counsel, Department of Mental Health 11-13 (Mar. 2, 1981) (on file with the California Law Review). Chell was also interviewed by telephone on several occasions.

478. Chell found his mandate for his massive undertaking in two recent lawsuits: Doe v. Gallinot, 486 F. Supp. 983 (C.D. Cal. 1979), affd, 657 F.2d 1017 (9th Cir. 1981) (14-day certification provision of LPS fails to provide sufficient due process safeguards for persons involuntarily confined on grounds of grave disability), and Jamison v. Farrabee, No. C78-0445 (N.D. Cal. anended coinplaint filed Sept. 15, 1978) (challenges current procedures for administering psychotropic medication to involuntary patients). The effort has been furthered by frustrations built up over the ten-year history of LPS. Chell transcript, supra note 477, at 8, 13,15; Chell, Reexamination, supra note 477 , at 2-3.

479. Chell, Reexamination, supra note 477.

480. Id. at 14. 
to make decisions regarding his care and treatment as a result of the mental disorder. ${ }^{481}$ Chell urged legislation defining incompetency and requiring a findimg of incompetency as a prerequisite to involuntary civil commitment. ${ }^{482} \mathrm{He}$ also urged provisions for "the efficient appointinent of a substitute decisionmaker to provide (or withhold) consent for the treatment of the involuntarily committed person."483

To implement the suggested statutory criteria for mental commitinent in a sound procedural fashion, ${ }^{484}$ Chell proposed automatic, state-initiated admmistrative review of every decision to certify a patient for involuntary hospitalization within seven days after the patient's initial commitment. ${ }^{485} \mathrm{He}$ concluded that administrative review would be more practical in view of the numbers of patients involved and the inability and reluctance of the courts to add a greater burden to their existing workload. ${ }^{486}$

To the extent that the "voluntary" commitment of minors by their parents is recognized as involuntary on the minor's part, as Roger $S$. acknowledged for minors over fourteen, provisions for commitment of minors would logically find a place in the revised Act. ${ }^{487}$ Chell argued that the way to implement Roger $S$. was to develop procedural inechamisuns for involuntary commitments in general and then utilize those mechanisms for mimors, with appropriate inodifications to comply with Roger $S$. requirements and with the special interests of children and their families. ${ }^{488}$

Chell expressed skepticism, however, about the conceptual basis for including provisions for minors in the LPS revision. Chell viewed the Roger $S$. issue as essentially a private matter, an exercise of parental authority rather than an exercise of state authority, which is the issue in LPS involuntary civil commitment. Developing procedures to

481. Id. at 16. Chell derived the concept of a person "in a dangerous situation" from the Doe v. Gallinot court's holding that standards for commitment to mental institutions are constitutional only if they require a finding of dangerousness to others or to self. Id. at 24-26.

482. Id. at 51. Chell views the right-to-refuse-treatment cases as arising from the absence of a statutory provision for findings of incompetency in civil commitment systems, simce there is no jnstification for forcibly treating mentally ill people, even if they are in a dangerous situation, if they are capable of making treatment decisions theinselves.

483. Id at 50-51. A substitute decisionmaker would clearly identify the source of consent to treatment of the patient and leave the onus on the individual physician only for malpractice. $I d$. at 58 .

484. Id at $62-63$.

485. Id. at 92. Chell also recommended extension of the current 14-day certification period to 28 days and the elimination of temporary conservatorships and special provisions for suicidal patients. Id. at 96.

486. Id. at 80 .

487. LPS did not provide any procedures for minors, on the assumption that CAL. WELF. \& INST. CODE $\$ 6000$ (West 1972) (current version at Supp. 1981) made the necessary provisions. Fraser interview, supra note 294.

488. Chell, Reexamination, supra note 477, at 100-01; Chell transcript, supra note 477, at 6 . 
govern an intrafamily dispute presents complicated questions regarding the role of the inental health professional and the source of payinent of attorneys for child and parent. ${ }^{489}$ Chell also anticipated that Roger $S$. would be inore expensive than otler provisions in a bill to revise LPS and would therefore be the first to be deleted. 490

The revision proposal inet expected resistance from those psychiatrists who prefer to ineet the bare minimum requirements of court decisions and gainble on the possibility that the trend toward increased procedural rights will be reversed. ${ }^{491}$ However, Chell's efforts achieved widespread support for restructuring LPS from the inental health community ${ }^{492}$

By mid-1981 a draft statute of the LPS revision that incorporated many of the Roger $S$. provisions from the original version of the Sieroty bill ${ }^{493}$ was inaking the rounds of government offices. The proposed statute was approved by the Department of Mental Health and by the Health and Welfare Agency. When the package went to the Departinent of Finance for assessment, however, it caine back with a cost projection that would probably preclude administration approval. ${ }^{494}$ Without such approval, the Department of Mental Health would not be able to seek an author for the proposed bill. Sponsorship of any portion of the bill by an organization other than the department would be unlikely in view of the energy that would be required to tackle its coinplex and controversial issues. ${ }^{495}$

\section{B. The Future of Roger S. Legislation}

The lingering controversies between the inedical perspective of mental health providers and the legal perspective of children's rights advocates over what provisions belong in a bill, combined with the active resistance to any regulation by doctors associated witl private fa-

489. Chell transcript, supra note 477, at 3-4.

490. Telephone interview with Chell, supra note 477 (Sept. 15, 1981).

491. Diainond transcript, supra note 373 , at 7.

492. Knepprath interview, supra note 332 (Nov. 19, 1981).

493. See supra text accompanying notes 449-57. Like the revised Sieroty bill, Chapter 6 of the proposed LPS statute, by authorizing admission when the minor signs the waiver, departed froin the Lanterman model of providing for review of waivers. Compare LPS revision $\$ 5156$ and S.B. $1016 \S 6024$ (as amended July 1, 1981) with S.B. $1016 \S 6025$ (as introduced Mar. 27, 1981) and A.B. $3648 \S 5133$ (as introduced Apr. 4, 1978). The LPS proposal stressed informality in the hearing "to encourage free and open discussion by participants." LPS revision § 5158(b).

494. Telephone interview with Chell, supra note 477 (Sept. 15, 1981).

495. Id. Compare the enactment of LPS in 1971 through a massive bipartisan effort by Assemblyman Frank Lanterman and Senators Nicholas Petris and Alan Short. For a detailed account of the painstaking politicking that preceded the passage of the Act, see Bradley, California Moves Rapidly to Community-Centered Mental Health Program Under 1967-68 Legislation, 3 CAL. J. 182 (1972). 
cilities, may be fatal to future legislative efforts. A former staff member of the Assembly Office of Research has observed:

The legislature does not so much pass these bills as abstain from vetoing them. If there is not a united group or the governor pushing Roger $S$. legislation, the legislature will veto it. Only if some proposal comes forward which has a united community behind it will the legislature not veto it by inaction. ${ }^{496}$

Indeed, the longer the mental health system fumbles along without legislation to implement Roger $S$., the less urgent appears the plea for legislation..$^{497}$

The most significant barrier to successful legislation is the diffculty of accommodating the diverse perspectives of the various interested groups in light of the financial implications of potential compromises. Provisions that are considered crucial by some groups are more costly than alternative provisions favored by other groups. For example, those who insist that an attorney is required to consult with every mimor who wants to sign a waiver are proposing a much costlier bill than those who mamtam that patients' rights advocates can adequately advise minors of their rights and that attorneys' fees can be limited to the small percentage of minors who request hearings. ${ }^{498}$

Similarly, preadmission screening entails greater expenses the more thorough it is and the more personnel it involves. Some complam that allowimg private physicians to screen admissions to non-state hospitals creates a fox-and-henhouse situation because the private physician lias already decided that the child should be hospitalized. ${ }^{499}$ They behieve the purpose of a statutory screening process should be to review the need for and the appropriateness of hospitalization and to assure that the least restrictive available treatment program is selected. On

496. Telephone interview with Dan Chandler, formerly of the Assembly Office of Research, now chief, Planning and Evaluation, Sacramento County Division of Mental Health (Oct. 6, 1981). Chandler notes that legislation introduced in 1980 by Senator Petris to provide a probable cause hearing for 14-day hospitalization in compliance with Doe v. Gallinot, 486 F. Supp. 983 (C.D. Cal. 1979), aff d, 657 F.2d 1017 (9th Cir. 1981), was dropped because “there wasn't a united commumity behind it." Chandler interview, supra.

497. One of the drafters of the Lanterman bill has observed:

There was a lot of concern by the doctors that we were getting into an area that we didn't belong in. If we had gotten some support for the bill [im 1978], we could have gotten it through. We may lave missed our opportumity. The bill was running one million dollars in 1977. Any legislation that cost that inuch now would be put through the wringer more now than it was four years ago. The lawmakers will say, "What have you been doing for four years?"

The doctors basically sat on their hands at the time, and now it may be too late.

Slavney interview, supra note 290.

498. There are apparently divisions within the Department of Mental Health on this question. The legal office recommends the use of an attorney, while the Office of Children and Youth, as well as most county officials, believes a patients' rights advocate is sufficient. Stein interview, supra note 343.

499. Id. 
this view, no child should be hospitalized without such a screening. Others contend that the state should have no involvement with the commitinent decision when it is not funding the treatinent. It is troublesome enough in developing legislation to contend with such divergent views. The fact that these two views have very different financial imphcations imevitably complicates legislative efforts.

Even if the interested groups could set aside their differences sufficiently to present a united front, they would have to overcome the low priority assigned to costly mental health proposals by a legislature that has far fewer funds to allocate than it has demands for services. The experience of the Lanterman and Sieroty bills shows the crucial role that cost estimates play in determining the success of a proposed bill. ${ }^{500}$ Given the pohtical climate, the legislature does not want to buy anything that it does not have to buy. ${ }^{501}$ The Roger $S$. holding did not require the legislature to buy new niental health procedural niechanisms. The holding required only that Welfare and Institutions Code section 6000 (b) not be utilized to commit minors to state hospitals against their will and that no child be committed against his will without some sort of hearing. LPS provides a substitute for new legislation simce it affords minors a hearing for involuntary commitnient. Its drawback is that a child must meet the gravely disabled standard-a stricter standard than Roger $S$. required-in order to be hospitalizcd.

Roger $S$. held that the society may provide for the hospitalization of minors agamst their consent when parents and physicians deein the treatinent appropriate, even if the child is not gravely disabled, so long as an independent screener assures that the treatment will benefit the child. The court assumed the existence of some societal commitnient to the parental autonomy nodel since it expressly included parents' interests in structuring the minimum set of constitutionally required procedures. This nieans that the society should not treat minors as adults for purposes of involuntary mental hospitalization. By noting its expectation that the legislature would act to implement the decision, the court also assumed that the legislature would reflect and express such a commitment to parental autonomy.

Contrary to the court's expectation, it appears that a legislative commitment to parental autonomy does not exist. The legislature is apparently deciding (by default) not to provide at all for the hospitali-

500. Some analysts predict enormous costs on the assumption that no adolescent will forego the opportunity to engage in a legal battle with his parents. Others estimate that only $10-20 \%$ of the minors involved would request a hearing if the consultation regardimg waiver procedures is handled properly. Knepprath interview, supra note 332 (Oct. 1, 1981); Stein interview, supra note 343. The figures are based on state hospital admissions and a questionnaire returned by children's coordimators to the inental health programs.

501. Knepprath interview, supra note 332 (Oct. 1, 1981). 
zation of minors when they are in need of publicly financed treatment but are not gravely disabled under LPS standards. As a result children are in fact often treated as adults, since the interim procedure used by inany county agencies is the adult model embodied in LPS.

Tliose who participated in tlie Roger $S$. litigation on botli sides, as well as all those who have pressed for implementing legislation, would probably consider this a sliortsiglited approach that neglects the long term societal costs of untreated mental illness in children. ${ }^{502}$ The tenor of the court's opimion indicates that it did not intend societal abandonment of hospitalization as a metlod of treatimg nondangerous minors whose parents cannot afford private hospitals. However, as one of the drafters of the current Roger $S$. legislation has observed: "Tlie court frequently speaks in an unclear voice. No doubt the court issues many decisions which aren't absolute because it's trymg to avoid legislatimg, but this results in confusion until legislation is finally enacted, and makes the business of trying to write laws to impleinent the decision very difficult." ${ }^{503}$

As the prospect of a legislative resolution of the confusion experienced by those in the mental health system grows dimmer, the suggestion lias begun to circulate that, in the absence of legislation, the simplest way to clarify the issues regarding tlie scope of the decision would be by relitigating Roger $S .504$ A Los Angeles County Superior Court judge has found that Roger $S$. applies to minors lospitalized in private hospitals. ${ }^{505}$ This directly contravenes the attorney general's

\section{As one observer has noted:}

Society pays a very high price for the way we deal with disturbed children, but they don't care because the costs are hidden. Politicians and bureaucrats look at costs in terms of the next fiscal year. That's the priority. What the cost to society is in the next decade-the multi-agency costs, police, education, welfare, mental health-that cost is never put together, never broken out, never totalled up, and nobody's responsible for it.

[The] difficulty isn't dumping, but lack of care when it could be helpful-at 4 to 5 when [the child] enters school. . . . But there's not enough [care] out there, and little kids don't pose the same problems when they are little and easier to control. Only when they get [to be] 12 or 13 and are able to hurt people and property do they become public menaces. That's when kids get put away. But [the child has] lost $50 \%$ prognostically, and the treatment has to take longer.

Spicer transcript, supra note 116 , at 5.

503. Knepprath interview, supra note 332 (Oct. 1, 1981).

504. I reread the case recently and I'm almost convinced we ought to relitigate Roger $S$. It looks as though the court had some misconceptions about the situation-what were they thinking? It was crazy to apply it only to state hospitals. They seemed to be viewing it as state action-as though the state was detaining children like the state detains adults. What is the conceptual basis for making the state pay for a family dispute? And Parham has come out since then . . . .

Telephone interview with Chell, supra note 477 (Sept. 15, 1981).

505. In re Application of an Allegedly Mentally Disordered Person, MD 04472 (Los Angeles County Super. Ct. Nov. 6, 1981) (transcript on file with the California Law Review). See supra text accompanying notes 217-26. 
opinion $^{506}$ that $R o g e r S$. does not apply to privately funded treatment at private facilities. The attorney general's opinion may encourage private hospitals, many of which became cautious after Roger $S$. about the terms on which they adinitted minors, ${ }^{507}$ to admit more nonconsentimg minors on their parents' signatures. The stage may thereby be set for a court challenge of the applicability of Roger $S$. to private facilities. Such litigation would no doubt find the medical perspective more articulately represented than it was in Roger $S .{ }^{508}$

Litigation clarifying the scope of the Roger $S$. decision would provide a clearer guide as to what legislation would be appropriate ${ }^{509}$ and would probably decrease the controversies among the interested groups. The development of interim Roger $S$. procedures, such as those being attempted in Los Angeles ${ }^{510}$ and San Diego, ${ }^{511}$ will provide experience on which a bill could be based ${ }^{512}$ and might provide workable models for drafting specific provisions. Clearly a bill that provided only for minimal comphance with Roger $S$. and subsequent mental health decisions would have the best chance of passing the legislature because it would be viewed as the least expensive. For those concerned with integratimg the legal and medical perspectives, such minimal comphance would no doubt always be unsatisfactory. Conceivably a rightto-treatment lawsuit, by a parent in a county where the absence of Roger $S$. procedures precluded the commitment of a child who met Roger $S$. but not LPS criteria for commitment, might ultimately result in the legislature providing Roger $S$. procedures. The likelihood of success of such litigation and its impact on the legislature is speculative at best and beyond the scope of this Comment.

\section{VII \\ CONCLUSION}

\section{A. The Results of Roger $\mathrm{S}$.}

The Roger $S$. case and its aftermath tell the story of an attempt to establish and iniplement due process rights. Each of the three primary participants in the case-the lawyers advocating on behalf of Roger, the lawyers advocating on behalf of the state, and the California Supreme Court-had a different conception of what form the child's due process rights should take. They each tried, and failed, to bring the real world into accord with their conception of how it should be.

506. Op. Att'y Gen. No. 80-812 (1981). See also supra note 474 and accompanying text.

507. S. Wasserman, supra note 107; Lurie imterview, supra note 293 (June 18, 1981).

508. Chell transcript, supra note 477 , at 15-16.

509. Knepprath interview, supra note 332 (Jan. 5, 1982).

510. See supra text accompanying notes 408-18.

511. See supra text accompanying notes 419-27.

512. Knepprath interview, supra note 332 (Jan. 5, 1982). 
The Roger $S$. decision represents an effort to accommodate the philosophical perspectives of both sides in the litigation. Roger's lawyers, advocating the merits of the legal model, sought a broad grant of due process rights. The state's lawyers, on the other hand, adopted the medical model, arguing that minors' rights were adequately protected by the screening of mental health professionals. The court attempted to fashion a modified legal model by requiring an independent review of commitment decisions without some of the procedural safeguards common to judicial review of similar decisions under LPS for juvenile wards of the court.

The court, however, left the details of creating a replacement for section 6000 (b) to others by suggesting that the legislature pass a bill covering adolescent commitments. The court apparently failed to realize that those affected by the Roger $S$. decision did not forin a constituency that can effectively lobby the legislature to spend money to create a new system. Without an effective political force pushing for a new bill, the legislature has not passed a Roger $S$. bill and it is unlikely to do so in the foreseeable future.

This legislative maction has directly affected the operation of the state's mental health system. ${ }^{513}$ The state hospitals receive far fewer voluntary admissions smce inost patients now enter under LPS conservatorships. A few counties have adopted Roger $S$. procedures on their own, but in the absence of a bill, most have been forced to rely on the imterim measures suggested by the court: waivers and LPS conservatorship proceedings. Waivers are not always available in counties that require a lawyer to witness waivers and in which the local public defender refuses to participate.

Absent Roger $S$. procedures or a waiver of Roger $S$. rights, children are committed to a state mental institution through conservatorship proceedings under LPS. LPS gives the potential conservatee far more procedural protections than the Roger $S$. court required, mcluding jury trial and proof beyond a reasonable doubt. By failing to pass a Roger $S$. bill, the legislature has forced the use of LPS as a commitment vehicle, thereby giving children far more due process rights than they had won from the court. Thus, legislative inaction has turned a qualified victory for the legal inodel into a rout.

Hence, Roger $S$. has a twofold impact on mimors. Adolescents like Roger now have due process rights and greater assurance that they will not be inappropriately committed to a state mental hospital. On the other hand, rehance on LPS, which was intended to cover individuals far inore dysfunctional than adolescents like Roger, has the potential of

513. For a view of the problems legislative inaction has caused from the standpoint of a California superior court judge, see Lachs, supra note 379. 
screening out some adolescents who need imstitutional treatment because the LPS standard of gravely disabled is much stricter than the Roger $S$. "likely to benefit" standard. It is not possible to give an empirical answer as to which impact is greater, and Roger $S$. therefore remains a mixed blessing for adolescents.

For those responsible for administering the state's mental health systein, Roger $S$. has been a continuing problem. The various inental health organizations continue to spend time and inoney lobbying for legislative action. County admissions persolmel continue to imvestigate how to coinply with the decision; as new procedures are suggested, county resources are used in reorganizing commitment processes. The result is that the uncertainty created by the decision has given many of these people an extremely negative view of the role the legal model plays in the mental health systein.

\section{B. The Three Perspectives}

To provide a general framework for analysis of the imvoluntary commitunent of children to mental hospitals, this Comment considered three perspectives: parental autonomy, the medical model, and children's rights. The court's opinion took all three perspectives into account. Some useful inforination bearing on these perspectives was obtained in the course of this study.

One of the inajor problems associatcd with parental autonomy is the potential for "duinping" - the placement im mental hospitals of children whose parents do not want them but who are not mentally disturbed enough to need institutional treatment. County mental health workers provided no infornation indicating that dumpimg has ever been a serious problem, and this study found no evidence of dumping at Napa State Hospital, although this could be the result of rigorous admission criteria necessitated by a lack of state funds. This study obtained no direct infornation on private facilities, but some of the people imvolved in the attempts to enact Roger $S$. legislation believe that dumping is a more serious problem there. A private facility, where parents pay for the hospitalization, has less incentive than a state funded facility to reject improper commitments, and parents with the ability to pay can shop for a private facility that will commit their child.

A second problem is whether some parents actively resist psychiatric treatinent for their children. The reports of some doctors and other inental health personnel involved in LPS conservatorships suggest that parental resistance is significant. Any analysis of the parental role in commitment must therefore take account of parental resistance as well as dumping.

The medical perspective rehes on mental health persoiniel to con- 
trol hospital admissions. It involves a very diverse group of people including publicly and privately employed psychiatrists, other doctors, psychologists, and social workers. The unifying aspect of the medical perspective is the belief that judges and lawyers should not control commitment decisions. Substantial differences exist, however, in the approaclies of inental liealtli professionals to commitinents. For example, because of the high cost of institutionalization and a lack of state funds, mental health professionals in the public sector appear to be inotivated to choose less restrictive, and hence less costly, forms of treatment. Mental health professionals in the private sector, who are not dependent on limited public funds, may not be similarly motivated. Thus, generalizations about the efficacy of the medical model to screen hospital admissions may mask substantial differences among the various facilities that exist.

Theoretically, the legal perspective aims to protect children's rights by providing a mechanism to screen the decisions of parents and inental liealth professionals. To be effective, legal review must be carefully tailored to the needs of children and others who are affected. Legal involvement that is too extensive or too rigid can disrupt treatment programs and relationships unnecessarily. On the other hand, legal review that is perfunctory or overly deferential to mental health professionals is little more than a rubber stamp of the inedical perspective. Hence, legal involveinent slrould be flexible and sensitive so as not to be overly disruptive, but the procedures and standards used inust nonetheless assure a meaningful review of the commitment.

\section{Suggested Procedures for Implementing Roger S.}

Although the legal and medical nodels appear to be in conflict, they are not mutually exclusive. Conceptually, the decision by the government to put an unwilling child in a locked institution-to deprive the child of biberty-is a legal one. A inajor coinponent of the decision to commit a child, however, is a nnedical determination of the inental condition of the child and the appropriate treatment. The problem is how best to structure the decisionmaking process so as to utilize the expertise of mental liealth professionals and protect the child's constitutional due process rights at the same time.

The heart of any review procedure is the hearing. A formal hearing in open court, however, is not necessary. An informal hearmg, perhaps conducted in chambers mucli like a settlenient conference, could both protect the child's due process rights and minimize whatever einotional harm umight be caused by an adversary hearing. Although both sides would offer evidence, presenting this evidence in a less formal and 
adversarial setting than a typical courtroom hearing would reduce the likelihood of exacerbating familial and individual problems.

The Roger $S$. standard for commitment, "reasonably likely to be beneficial" to the child, is a good startimg point. It is broad enough that the decisionmaker can consider both medical and nonmedical factors. The mental condition of the child and the possibilities for treatment are key considerations in the determination of what is likely to be of benefit to the child, and in this way the standard properly makes the use of medical expertise an important part of the hearing.

The hearing should also focus on available treatment alternatives and their appropriateness. Determining what is "reasonably likely to be beneficial" to a child requires a knowledge of available alternatives; indeed, the Roger $S$. court emphasized that alternatives should be considered. For example, commitment may not be "beneficial" for a certain child because another more appropriate alternative is available. On the other hand, it is possible that commitment will be "beneficiar" for a child only because it is the least detrimental of the available alternatives. Because the primary purpose of the hearing is to determine whether the child should be deprived of liberty, the decision must also take into account the extent to which various alternatives will impinge upon the child's liberty interest. The hearing may thus be seen as an attempt to determine which alternatives are both available and appropriate, and of those which are the least restrictive.

If the hearing is inforinal and its focus is on determining the least restrictive, appropriate alternative, then it is unnecessary to require a procedure for waiving the right to a hearing. If the child is not opposed to the commitment, he might waive some of the procedural rights imcident to the hearing such as the right to be represented by counsel. In such a case, the hearing would become a vehicle for the concerned parties-mcluding the family - to demonstrate to a judge or referee that no less restrictive, appropriate placement is available. This would provide additional assurance that commitment to a mental hospital is the best option for the child.

This independent review of the commitment decision should also be available when parents seek to admit an adolescent to a private facility. Roger $S$. itself probably does not apply to private facilities because there is no state action in a private commitment. Nevertheless, the possibility of psychiatric error exists at private as well as public facilities. The potential for dumping may be even greater at private facilities, where there is no financial incentive to restrict commitments. Thus, legislation implementing Roger $S$. procedures slould apply to both public and private facilities. 


\section{Suggested Interim Procedures}

The Roger $S$. court noted that, pending legislative enactinent of a replacement for section 6000 (b), adolescents could be committed via LPS conservatorships. LPS, however, was never intended to apply to adolescents like Roger. Its commitment standard and its hearing mechanism are inappropriate for these children.

Although the court correctly realized that any interin procedure would have to be appended to soine already existing structure, the court should have recommended that Roger $S$. hearings be held in superior court. Solne counties have found this approach feasible. Superior courts already have mechanisms for scheduling, providing notice of, and recording hearings. Most already have a regular mental health calendar to which Roger $S$. hearings could be added. Moreover, because superior courts regularly handle a variety of mental health inatters, they are familiar with the issues that a Roger $S$. hearing would pose. A superior court judge or a referee attached to the court would certainly qualify as the neutral factfinder required by the Roger $S$. decision.

\section{E. A Lesson of Roger $\mathrm{S}$.}

Roger $S$. and its afterinath deinonstrate the probleins of putting due process into practice. Establishing due process rights is properly within the scope of judicial functions. Indeed, the difficultics encountered in trying to pass a Roger $S$. bill indicate how difficult it would be to establish those rights legislatively. Defining procedures to implenent those rights, lowever, is a legislative and admimistrative function. The courts have no direct control over low legislatures and administrators implement the court's decisions.

The Roger $S$. court assumed that the legislature would act promptly to implement and give definition to its decision. In retrospect, this was a mistake. The legislature's inaction confused and disrupted the state's mental health system. The court had granted children some due process rights, but no one told the people running the inental health system how these rights could or should be implemented. They were left on their own to figure out low the court's general due process language sliould be put into practice. Many understandably threw up their arins and chose, despite the drawbacks, to rely simply on LPS.

Many of the problems, however, could have been avoided if the court had anticipated thein. Even if the legislature had acted with unusual speed, many months would liave passed between the court's decision and the implementation of any new procedures. When a large decentralized system like California's inental health system is told that 
it can no longer use existing procedures and is not given any substitutes, a certain amount of chaos is to be expected. Mandating permanent procedures is a legislative task. But if the court had provided adequate interim guidance to the various coinponents of the inental health system, much of the chaos that followed Roger $S$. need not have occurred.

Lawyers who litigate cases like Roger $S$. must assist the court in filling the gap a decision may create. One problem witl test case litigation is that the court is shown how one person was treated by the system but may not be shown liow the system operates in its totality or low all the pieces fit together. ${ }^{514}$ The advocates sliould therefore provide the court with information about low the whole system operates, how a court decision miglit affect the operation of the system, and low potential problems can be avoided.

In sum, courts and lawyers inust take great care to anticipate the problems that may arise in the implementation of decisions that liave a broad impact. A failure to anticipate these probleins, as in Roger $S$, can seriously harm the very group that the decision is intended to benefit.

Carol K. Dillon

Margaret Rockwell Roisman

Joel $S$. Sanders

Betsy Buchalter Adler*

514. See Wald, Litigation Should be Approached Very Cautiously, 1 CHILDREN's RIGHTS REP. 3 (1977).

* Carol K. Dillon, B.A. 1975, Stanford University; third-year student, Boalt Hall School of Law, University of California, Berkeley.

Margaret Rockwell Roisman, B.A. 1967, Oberlin College; third-year student, Boalt Hall School of Law, University of California, Berkeley.

Joel S. Sanders, B.A. 1976, Antioch College; third-year student, Boalt Hall School of Law, University of California, Berkeley.

Betsy Buchalter Adler, B.A. 1971, University of California, Santa Cruz; M.A. 1973, San Francisco State University; third-year student, Boalt Hall School of Law, University of California, Berkeley. 
APPENDIX A

Your Name \& Title

County Use Napa? Use Camarillo?

Average number of minors at state hospital at any given time

Can you break this total down between those over and under age 14?

What role does the state hospital play in your overall treatment scheme?

Can you compare the impact of the Roger $S$. decision to the earlier effects of the Michael $E$. decision?

Has Roger $S$. affected the types of patients referred to you or the types you refer on to the state hospital? How?

Has Roger $S$. reduced the number of patients you send to the state hospital? Any statistics?

What proceedings do you use to accomplish admission? (Waivers, Roger $S$. hearings, conservatorship?)

\section{Conservatorship:}

How and when is the decision made to seek a conservator?

How many conservatorship hearings held annually?

How often demed? Why?

What alternative disposition upon denial?

What is parents' role im conservatorship? Cooperative? Resistant?

How do parents respond to process im general? Using private alternatives?

\section{Waivers:}

How presented to child? Are all children asked?

Who witnesses waivers? Is Public Defender involved?

How nrany waivers given amually?

Accepted by state hospital admissions staff?

Do families and inental health professionals influence child's decision?

How well do children understand? Is 14 the appropriate age to offer due process rights? Too old? Too young? 
Roger S. Hearings:

What procedures? (Who conducts hearings, who represents child, open or closed, how process devised, etc.)

How often are hearings held?

Any children turned down for admission as not likely to benefit? Why?

How well does this proceeding meet your needs?

What other facilities do you use besides the state hospital that require one of these proceedings before admission?

Does your county have any long-terin residential treatment facilities? What are your basic alternatives to state hospitalization?

Has the Roger $S$. decision mcreased reliance on those alternatives?

Has Roger $S$. mcreased the number of alternative placements prior to admission to the state hospital?

Has Roger $S$. had an impact on the procedures for treating children who are not yet being considered for state hospital (or locked ward) treatinent? For example, is it affecting you at the initial intake level? Have state guidelines been useful to you? Do you have any guidelines of your own? (We would appreciate copies)

Would a coinprehensive legislative scheme help you at the county level?

What do you think of current proposed legislation?

Have you considered or imight you eventually institute Roger $S$. proceedings in the absence of legislation? Why or why not? 
Appendix B(1): General

\begin{tabular}{|c|c|c|c|c|c|c|c|}
\hline County & $\begin{array}{c}\text { State } \\
\text { Hospital }\end{array}$ & $\begin{array}{l}\text { Average } \\
\text { Patients }\end{array}$ & Conservators & Waivers & Rogre S. Heanogst & $\begin{array}{c}\text { Role of Stale } \\
\text { Hospital }\end{array}$ & $\begin{array}{c}\text { Chasges in } \\
\text { Patieat Types }\end{array}$ \\
\hline Alameds" & $N_{\Delta p 2}$ & 14 & yes & yos & no & $\begin{array}{l}\text { actively } \\
\text { tring to } \\
\text { seduce }\end{array}$ & $\begin{array}{l}\text { generally } \\
\text { must be cos. } \\
\text { servable }\end{array}$ \\
\hline
\end{tabular}

\begin{tabular}{|c|c|c|c|c|c|c|c|}
\hline Calaveras & Nap: & 0 & $\infty$ & no & $\begin{array}{l}\text { would use if neces } \\
\text { sary }\end{array}$ & Lest steon & $\mathrm{a} / \mathrm{a}$ \\
\hline Coluss & $N_{2 p a}$ & 1 & $\infty$ & yes & yes & $\begin{array}{c}\text { very } \\
\text { imporizot }\end{array}$ & no \\
\hline Contra Costa & Naps & - & yes & yes & no & $\begin{array}{l}\text { have been } \\
\text { overasing }\end{array}$ & - \\
\hline Del Nore" & Detber & 0 & $\infty$ & no & no & - & - \\
\hline Freseo & $N_{\text {apz }}$ & 0 & yes & no & no & alnots no & no \\
\hline
\end{tabular}

\begin{tabular}{|c|c|c|c|c|c|c|c|}
\hline Inyo & Camanilo & $t$ & no & $\infty 0$ & yes & $\begin{array}{l}\text { smalt but } \\
\text { necessary }\end{array}$ & Do \\
\hline Kern: & Napz & $3-4$ & unknown & unkrown & unknown & Dol much & $\omega$ \\
\hline Lesced & Napz & 0 & unksown & unksown & unknown & $=$ & $=$ \\
\hline Los Angeles & Both & 120 & yes & yes & developing & $\begin{array}{l}\text { primary } \\
\text { tescusces for } \\
\text { acutely } \\
\text { disturbed }\end{array}$ & dectine \\
\hline Madera & Napz & 1 & yes & yes & so & very títle & no \\
\hline Mann" & Naps & 3 & yes & yes & yes & Lest resont & - \\
\hline Mariposs & Napt & 0 & $\infty$ & Do & Do & very titile & no \\
\hline Merced & Napa & 0.1 & yes & yes & no & very limited & no \\
\hline Moatere & Napa & 2 & D & yes & no & minot & Do \\
\hline
\end{tabular}

\begin{tabular}{|c|c|c|c|c|c|c|c|}
\hline Riverside & Camintlo & 10 & yes & yes & no & chronis cast & yes \\
\hline Sacrusento & Napa & 7 & $y=s$ & no & $\infty 0$ & $\begin{array}{l}\text { when all } \\
\text { other } \\
\text { resources } \\
\text { exhausted }\end{array}$ & $\begin{array}{l}\text { alternative } \\
\text { resources } \\
\text { developed }\end{array}$ \\
\hline San Diego" & Cameritto & 10 & yes & yes & developing & $\begin{array}{l}\text { seute care of } \\
\text { specife } \\
\text { problems }\end{array}$ & $\begin{array}{l}\text { more } \\
\text { deteriorated }\end{array}$ \\
\hline Sas Francisco" & $N_{a p 3}$ & 15 & yes & yes & Eo & $\begin{array}{l}\text { when no local } \\
\text { resource }\end{array}$ & $\begin{array}{l}\text { yes - ellmi- } \\
\text { pates } \\
\text { nonvoluntary } \\
\text { unconsen. } \\
\text { able }\end{array}$ \\
\hline Sas Joxquin & Neps & 12.16 & yes & yes & Do & $\begin{array}{l}\text { to keep from } \\
\text { harming telf }\end{array}$ & $\begin{array}{l}\text { more } \\
\text { paychotic }\end{array}$ \\
\hline Sen Mateo & Napa & $10-12$ & yes & uaknows & Do & $=$ & - \\
\hline Sence Clea* & Nape & 22 & yes & yes & developing & $\rightarrow$ & - \\
\hline Sentz Cruz & Napa & 6 & yes & Do & no & $\begin{array}{l}\text { oaly lons } \\
\text { term } \\
\text { residential } \\
\text { tresionest }\end{array}$ & $\begin{array}{l}\text { yen + mus be } \\
\text { conservable }\end{array}$ \\
\hline Stasta: & Naps & 4 & yes & Do & no & - & - \\
\hline Sonomx & $N_{1 p q}$ & 8 & yes & Do & no & $\begin{array}{l}\text { absoluite } \\
\text { necessity for } \\
\text { some }\end{array}$ & $\begin{array}{l}\text { yes - must be } \\
\text { gravely } \\
\text { dissbled }\end{array}$ \\
\hline Stanistaus & Nıp: & 8 & yes & yes & no & $\begin{array}{l}\text { only whes } \\
\text { unscotplable } \\
\text { tor mose } \\
\text { open setilos }\end{array}$ & Do \\
\hline Sulter/Yuba & Napa & 0 & Do & no & Do & Done & DO \\
\hline Veatun & Carranllo & 7 & $\infty$ & $y$ & Do & Last reson & $\begin{array}{l}\text { seceens out } \\
\text { Benvolustary }\end{array}$ \\
\hline
\end{tabular}

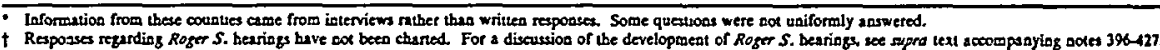


Responses of County OfFicials

\begin{tabular}{|c|c|c|c|c|c|c|}
\hline $\begin{array}{l}\text { Popilstion } \\
\text { Reductions }\end{array}$ & $\begin{array}{l}\text { Other Facilues } \\
\text { Requirag Due Proes }\end{array}$ & $\begin{array}{l}\text { In-County Long } \\
\text { Term Treastrent }\end{array}$ & $\begin{array}{l}\text { Altematuves to } \\
\text { State Hospital }\end{array}$ & $\begin{array}{l}\text { Increased } \\
\text { Relazece? }\end{array}$ & Yiews on Legislatton & $\begin{array}{l}\text { Plans for Roger } \\
\text { S Hearings }\end{array}$ \\
\hline $\begin{array}{l}\text { yes but uare- } \\
\text { lated }\end{array}$ & Do & Do & $\begin{array}{l}\text { residentual } \\
\text { treatment facaluy } \\
\text { or home }\end{array}$ & - & $\begin{array}{l}\text { 2ny legislation } \\
\text { would help }\end{array}$ & 20 \\
\hline $\mathrm{a} / \mathrm{*}$ & no & yes & $\begin{array}{l}\text { ecute facality. } \\
\text { group torres fos- } \\
\text { ter homes }\end{array}$ & no & not much impact & not necessary \\
\hline$a / 2$ & $0 / 2$ & $a / 2$ & group bomes & no & $\begin{array}{l}\text { "The legulature is } \\
\text { the problem." }\end{array}$ & "who knows" \\
\hline no & Dont & no & none & $n / 2$ & - & - \\
\hline- & - & - & - & - & - & $\begin{array}{l}\text { county counsel } \\
\text { has refused with- } \\
\text { out legislstion }\end{array}$ \\
\hline$=$ & - & $=$ & - & - & - & - \\
\hline Do & - & no & $\begin{array}{l}\text { day treatment, } \\
\text { group tomes: } \\
\text { topatueat. juvenale } \\
\text { hall }\end{array}$ & no & - & - \\
\hline no & nose & no & $\begin{array}{l}\text { group homes resi- } \\
\text { deatial faglitues }\end{array}$ & no & - & - \\
\hline$=$ & - & - & - & - & - & $=$ \\
\hline- & - & - & - & - & - & - \\
\hline $25 \%$ reduation & county hosprtals & yes & $\begin{array}{l}\text { transsuonal } \\
\text { residectial care }\end{array}$ & yes & $\begin{array}{l}\text { not useful without } \\
\text { funds }\end{array}$ & Dot lakely \\
\hline 20 & ose so Freseo & Do & $\begin{array}{l}\text { contract whth } \\
\text { Freseo }\end{array}$ & 20 & would not he]p & - \\
\hline- & - & - & yes & - & $\begin{array}{l}\text { need stalewide pro- } \\
\text { cedure }\end{array}$ & - \\
\hline no & $n / 2$ & no & $\begin{array}{l}\text { community } \\
\text { hospitsl for } 72 \cdot \mathrm{hr} \\
\mathrm{k} \text { 14-day holds }\end{array}$ & $0 / \mathbf{2}$ & $\begin{array}{l}\text { comprethensive } \\
\text { scherne would help }\end{array}$ & - \\
\hline$\infty$ & $\begin{array}{l}\text { loal 24-bour pychasa- } \\
\text { ne facluty }\end{array}$ & yes & - & - & - & - \\
\hline to & note & yes & $\begin{array}{l}\text { specializod foster } \\
\text { care group } \\
\text { homes, day treat- } \\
\text { ment }\end{array}$ & no & no comment & maybe \\
\hline yes & wo hosp:tals & $\begin{array}{l}\text { yes - for chul- } \\
\text { dren under } 12\end{array}$ & $\begin{array}{l}\text { acute local hospi- } \\
\text { tuls group homes }\end{array}$ & yes & necessary & $\begin{array}{l}\text { Do, county coun- } \\
\text { sel not in favor }\end{array}$ \\
\hline $\begin{array}{l}\text { yes, but unfe- } \\
\text { laled }\end{array}$ & - & yes & $\begin{array}{l}\text { 6-month } \\
\text { residential } \\
\text { treatreat cester }\end{array}$ & intendod & "defiantely seeded" & $\begin{array}{l}\text { probably wall } \\
\text { have to establish } \\
\text { more formal pro- } \\
\text { ccedings }\end{array}$ \\
\hline Do & yes & yes & $\begin{array}{l}\text { 24 hour schools. } \\
\text { group bomes }\end{array}$ & no & $\begin{array}{l}\text { necessery but cau- } \\
\text { tous about cutrent } \\
\text { propossls }\end{array}$ & in process \\
\hline sos reduction & yes & cone locked & $\begin{array}{l}\text { grousp homes day } \\
\text { treatcoent }\end{array}$ & yes & would help & $\begin{array}{l}\text { no- } 000 \text { costly, } \\
\text { no commuaty } \\
\text { interest }\end{array}$ \\
\hline increseat & cose & $\begin{array}{l}\text { regional } \\
\text { program being } \\
\text { developed }\end{array}$ & $\begin{array}{l}\text { residential } \\
\text { treatreast }\end{array}$ & Do & $\begin{array}{l}\text { "It would help af } \\
\text { they aeked elinj- } \\
\text { cians:" }\end{array}$ & $\begin{array}{l}\text { "No-no one } \\
\text { would astume } \\
\text { fonncial } \\
\text { responsibulity." }\end{array}$ \\
\hline$=$ & $=$ & - & - & - & - & $=$ \\
\hline- & $\infty$ & no & - & - & $\begin{array}{l}\text { statewnde system } \\
\text { would help }\end{array}$ & in process \\
\hline probably pot & yes & no & $\begin{array}{l}\text { group bomes, } \\
\text { acute hospitals }\end{array}$ & Do & $\begin{array}{l}\text { current propostl } \\
\text { scems too cumber- } \\
\text { some }\end{array}$ & probably not \\
\hline- & $\rightarrow$ & - & - & - & - & - \\
\hline S reduction & noce & yes & $\begin{array}{l}\text { residential } \\
\text { treatment }\end{array}$ & yes & $\begin{array}{l}\text { oeed legislation to } \\
\text { implement Roger } S .\end{array}$ & need legislation \\
\hline $\begin{array}{l}\text { yes, batt unre- } \\
\text { isted }\end{array}$ & Dose & $y e s$ & $\begin{array}{l}\text { group homes, resi- } \\
\text { dential ureztment. } \\
\text { loster homes, day } \\
\text { treatment }\end{array}$ & 20 & $\begin{array}{l}\text { may be belpfilh or } \\
\text { "multiply the work } \\
\text { and the headaches" }\end{array}$ & $\begin{array}{l}\text { have considered } \\
\text { waithing for legis } \\
\text { Lation }\end{array}$ \\
\hline 50 & none & so & $\begin{array}{l}\text { private residentual } \\
\text { treatment }\end{array}$ & no & - & - \\
\hline mumal & none & yes & $\begin{array}{l}\text { regional treatment } \\
\text { programen } \\
\text { treatment bomes, } \\
\text { foster homes }\end{array}$ & Do & can manaze witbout & $\begin{array}{l}\text { "No-sizaifeant } \\
\text { time at substan- } \\
\text { tial cost for litue } \\
\text { value" }\end{array}$ \\
\hline
\end{tabular}




\section{APPENDIX B(2): RESPONSES FROM COUNTIES THAT USE CONSERVATORSHIP}

\begin{tabular}{|c|c|c|c|c|}
\hline County & Nunber/Year & How Often Denied & $\begin{array}{c}\text { Alternatives Upon } \\
\text { Denial }\end{array}$ & Parents' Role \\
\hline Alameda* & - & $\begin{array}{l}\text { "the courts every } \\
\text { day turn loose peo- } \\
\text { ple that they know } \\
\text { are... ill" }\end{array}$ & $\begin{array}{c}\text { residential } \\
\text { treatment facility, } \\
\text { home }\end{array}$ & $\begin{array}{l}\text { (See supra lext } \\
\text { accompanying note } \\
\text { 366) }\end{array}$ \\
\hline Contra Costa* & - & $\begin{array}{l}\text { good rapport with } \\
\text { public defender so } \\
\text { not often chal- } \\
\text { lenged }\end{array}$ & - & 一 \\
\hline Fresno & $3-4$ & "seldoin if ever" & - & $\begin{array}{l}\text { "usually } \\
\text { cooperative" }\end{array}$ \\
\hline Los Angeles & \multicolumn{2}{|c|}{$\begin{array}{l}\text { In } 1980-81 \text {, the public guardian's office } \\
\text { investigated } 147 \text { cases, and took on } 88 \text { cases. } \\
\text { Probably one-half denied. }\end{array}$} & no information & $90 \%$ cooperative \\
\hline Madera & $\begin{array}{l}65 \text { (probably } \\
\text { includes adults) }\end{array}$ & seldoin & $\begin{array}{l}\text { voluntary services } \\
\text { or referrals }\end{array}$ & $\begin{array}{l}\text { generally } \\
\text { coo pative }\end{array}$ \\
\hline Marim & few & never & - & - \\
\hline Merced & $1-2$ & "not denied" & - & $\begin{array}{l}\text { usually at least } \\
\text { comptiant }\end{array}$ \\
\hline Riverside & $8-10$ & one-fourth & $\begin{array}{l}\text { None. Depends on } \\
\text { previous legal sta. } \\
\text { tus. }\end{array}$ & $\begin{array}{l}\text { generally in agree- } \\
\text { ment }\end{array}$ \\
\hline Sacramento & $6-10$ & seldom & $\begin{array}{l}\text { usually a ward and } \\
\text { stays in juvenile } \\
\text { court }\end{array}$ & coopcrative \\
\hline San Die $0^{*}$ & less than 20 & rarely & - & pe varies \\
\hline San Francisco* & $10-15$ & $20-30 \%$ & hoine & inixed \\
\hline San Joaquin & $2-3$ & $\begin{array}{l}\text { judge goes against } \\
\text { clinical diagnosis }\end{array}$ & $\begin{array}{l}\text { run away or juve- } \\
\text { nile court systein }\end{array}$ & cooperative \\
\hline San Mateo* & - & - & - & $\begin{array}{l}\text { (See supra text } \\
\text { accompanying note } \\
368 \text { ) }\end{array}$ \\
\hline Santa Clara* & - & - & $\begin{array}{l}\text { outpatient serviccs, } \\
\text { uvenile ustice }\end{array}$ & pe \\
\hline Santa Cruz & 4 & seldom & $\begin{array}{l}\text { voluntary programs } \\
\text { or law enforcement } \\
\text { facilities }\end{array}$ & $\begin{array}{l}\text { half cooperate, half } \\
\text { resist }\end{array}$ \\
\hline Shasta* & - & $\begin{array}{l}\text { courts generally } \\
\text { approve }\end{array}$ & - & - \\
\hline Sonoma & 7 & none & none & $\begin{array}{l}\text { relieved and coop- } \\
\text { erative }\end{array}$ \\
\hline Stanislaus & $\begin{array}{l}28 \text { since August, } \\
1975\end{array}$ & none & not applicable & usually resistant \\
\hline
\end{tabular}




\section{APPENDIX B(3): Responses fRom Counties that Allow WaIVERS}

\begin{tabular}{|c|c|c|}
\hline County & Witness & Frequency of Waivers \\
\hline Alameda* & private attorney & $5 \%$ of admissions \\
\hline Colusa & public defender & 0 to date \\
\hline Contra Costa* & public defender & rare \\
\hline Los Angeles & private attorney or public defender & one-third of admissions \\
\hline Madera & public defender & unknown \\
\hline Merced & patient advocate & 3/year to local facility \\
\hline Montercy & parents, therapist, attorney & unknown \\
\hline Riverside & public defender and county counsel & $2 /$ year \\
\hline San Diego* & $\begin{array}{l}\text { intake staff at local facility (minors' rights } \\
\text { advocate in 1982) }\end{array}$ & $\begin{array}{l}60 / \text { year to local facility none to state } \\
\text { lospital }\end{array}$ \\
\hline San Francisco* & public defender & $\begin{array}{l}\text { 5/year to state lospital } \\
36 / \text { year to local facility }\end{array}$ \\
\hline San Joaquin & private attorney & 6-8/year \\
\hline Santa Clara* & private attorney & $20-30 \%$ of admissions \\
\hline Stanislaus & public defender & once in 1980; never since \\
\hline Ventura & public defender & $8 /$ year \\
\hline
\end{tabular}

* Information collected froun interviews rather than written survey response. 
APPENDIX C

\section{ATTORNEY CERTIFICATION FOR ADMISSION OF MINOR}

TO A STATE HOSPITAL

WAIVER OF ROGER S. HEARING

I, certify, under penalty of perjury, that:

(1) I am an attorney duly admitted to practice in the State of California:

(2) My business address is

(3) I have been retaimed by

counsel to to provide legal advice and (hereinafter "minor").

(4) I am informed that minor is age 14 through 17 years;

(5) I am inforned that the parents or legal guardian of minor have applied for minor's admission to state lospital for the mentally disabled;

(6) I lave privately discussed with minor his or her proposed admission to a state hospital;

(7) I have thoroughly explaimed to minor the following facts:

(a) Minor has a right to object to admission to a state hospital;

(b) That minor may waive any objection and be admitted to a state hospital on the signature of his or her parents or legal guardian;

(c) That, if minor waives objection and is admitted, he or she may request to leave hospital at any time and may petition the court to issue a writ of habeas corpus;

(8) After minor's rights were explaimed, as described im No. 7, supra, minor, im my presence, made a free, voluntary, and intelligent waiver of his or her rights to object to placement im a state lospital.

Dated:

Attorney for Applicant 